Carolina Rodrigues de Almeida

\title{
Aplicação de genética molecular para diagnóstico de neurocisticercose e descoberta gênica em Taenia solium
}

Dissertação apresentada à Faculdade de Medicina da Universidade de São Paulo para obtenção do título de Mestre em Ciências.

Área de concentração: Psiquiatria

Orientador: Prof. Dr. Emmanuel Dias Neto

São Paulo

2005 
Carolina Rodrigues de Almeida

\section{Aplicação de genética molecular para diagnóstico de neurocisticercose e descoberta gênica em Taenia solium}

Dissertação apresentada à Faculdade de Medicina da Universidade de São Paulo para obtenção do título de Mestre em Ciências.

Área de concentração: Psiquiatria

Orientador: Prof. Dr. Emmanuel Dias Neto

São Paulo

2005 
"Se diante de mim não se abrir o mar, Deus vai me fazer andar por sobre as águas" 


\section{Ao meu pai}

Você me ensinou que vencer não é chegar em primeiro lugar... É nunca desistir no meio do caminho!

Dedico 


\section{À minha mãe, Karina e Gabriel}

Pelo amor incondicional, paciência sem limites e confiança, Por terem sido meus olhos quando não enxergava e minhas pernas quando não caminhava, Por transformarem minhas frustrações em desafios e por me mostrarem o valor de uma família unida.

Ofereço 


\section{À Alzira Denise Hertzog Silva,}

"Nada na vida é por acaso, tudo tem um propósito" e Deus está sempre conosco!

Espero que esta pesquisa possa beneficiar tantos quanto dela precisam.

Ofereço 


\section{Agradecimentos}

À Deus. Por mais esta vitória, por me fazer amar a ciência, especialmente a genética, pela oportunidade de trabalhar ao lado dos melhores profissionais, por fechar portas e abrir janelas, por me sustentar nos momentos de desespero e solidão, por provar-me tantas vezes que está sempre ao meu lado, mesmo nas piores situações da vida, por me ensinar a ser forte, a enfrentar desafios e a superar meus limites, por me dar a certeza de que eu posso todas as coisas nAquele que me fortalece.

Ao meu orientador Emmanuel Dias Neto, por estes dois anos de aprendizado intenso, pelo conhecimento transmitido, pela dedicação e investimento, pela oportunidade de desenvolver este trabalho com tranqüilidade e segurança, por ter permitido que eu fizesse parte do grupo e por dedicar seu precioso tempo na construção da minha formação científica. Muito obrigada!

Ao Prof. Dr. Wagner Gattaz, por receber minha pesquisa de braços abertos e por oferecer todas as condições para que ela se desenvolvesse da melhor maneira possível.

À Elida, pela incansável dedicação e ajuda com as fotos deste trabalho, por acreditar em mim e confiar na minha capacidade, por estar sempre disposta a me ajudar, tanto pessoalmente quanto profissionalmente, por me inspirar e me incentivar a dar o melhor de mim, pelas dicas, conversas, conselhos...pela convivência, carinho e companhia, e acima de tudo, pela amizade.

À minha irmãzinha torta Camila, por tantas coisas...por estar ao meu lado nos momentos em que mais precisei, por me ouvir e me respeitar, por confiar mais em mim do que eu mesma, por me ensinar alguns segredinhos básicos da vida, por me ajudar a ver o valor que tenho, pela cumplicidade e principalmente pela boa convivência conquistada.

À amiga Sheila, por todo apoio, dicas e força, pelo incessável esforço em me fazer acreditar em coisas melhores, por despertar minha coragem e por entender minhas aflições, sei que você sempre torceu da forma mais sincera e sua amizade é um conforto para mim.

Aos amigos do grupo, Bárbara, Fábio e especialmente ao Daniel, pelos conselhos e incentivos nos momentos mais difíceis, por sempre terem uma 
palavra de conforto, pelo apoio, dedicação, por todas as horas que passamos juntos, enfim, por estarem literalmente presentes na minha vida. À vocês, dedico essa frase: "Amigos são como anjos que nos levantam nas pontas dos pés quando nossas asas têm problemas, nos lembrando como voltar a voar".

À minha mais do que amiga Heloisa Muller. Por ser minha melhor amiga, confidente e companheira, pelas diversas vezes que rimos e choramos juntas, pela cumplicidade, dedicação a uma amizade sincera, pelo compartilhamento de experiências, por estar ao meu lado todos os dias, todos os minutos, todos os segundos...enfim, por ser a minha amiga super poderosa!

À minha querida amiga Sandra Cardoso, simplesmente por ser minha rocha, por não me deixar desistir nunca, por me fazer aprender a enxergar longe, por mostrar novos horizontes e possibilidades, acima de tudo por me ouvir, enxugar as minhas lágrimas e é claro, por me apresentar a oitava maravilha do mundo: Petit Gateou!

A todos os amigos do Laboratório LIM - 27, pelo carinho e pela torcida sincera, pela convivência maravilhosa e especialmente pela amizade.

À Dra. Adelaide Vaz e à Andréia Bartachini, pela colaboração no projeto, pelo apoio oferecido e pelas construtivas discussões e constantes troca de idéias que tanto auxiliaram na execução deste projeto.

Aos Drs. Luís Machado e Oswaldo Takayanagui, pelas amostras fornecidas e apoio no desenvolvimento do trabalho.

À Dra. Caris Nunes, pela importante ajuda com as amostras e principalmente pelo entusiasmo contagiante.

Aos Drs. Edmundo Grisard e Mario Steindel, por me receberem tão bem em seu laboratório, por colaborarem com a minha pesquisa e pelo compartilhamento de idéias que me ajudaram a entender a importância do meu trabalho.

Aos inesquecíveis amigos do Laboratório de Microbiologia e Parasitologia da UFSC, Cristiane, Rodrigo e Bibiana, por me receberem em seu grupo, pelas incessantes horas de trabalho, pelo empenho em me ajudar a resolver os problemas da tese, pelo otimismo na interpretação dos resultados, pelas inesquecíveis risadas, enfim, por terem se tornados meus grandes amigos. 
Ao amigo Luís André Pontes, pelo apoio no trabalho, pelas experiências trocadas e pela boa convivência.

À amiga Gislaine Cristina Roma, um dos maiores presentes da graduação, por ser infinitamente mais do que uma amiga, por me fazer acreditar que a verdadeira amizade supera o tempo e a distância, por todos os momentos que passamos juntas...muita saudade...

À todos os meus amigos que compartilharam das minhas alegrias e tristezas, incertezas e inseguranças, derrotas e vitórias, mas que sempre me apoiaram em qualquer decisão.

À toda a minha família (tio David, tia Alcione, tio Aires, tia Ligia, tia Valéria, tio Rudah, Baby, Bruninha, Bia, Fernandinha, vó Juju), que sempre me incentivou, sempre presente em todos os momentos da minha vida, orando, conversando, apoiando ou simplesmente me ouvindo. Muitas vezes choramos juntos e tantas outras sorrimos juntos também, mas vocês aqueceram meu coração nos dias mais frios da minha vida. Vocês são o meu maior e verdadeiro tesouro. Amo vocês!

À ABADHS, por ter tornado possível a conquista de um dos meus objetivos, o Mestrado; não só pela bolsa de estudos concedida, mas pela confiança e esperança empregadas nesta pesquisa, por todo apoio oferecido, sempre presentes e dispostos a colaborar. À todos vocês deixo os meus mais sinceros agradecimentos.

Ao CNPq, pelo apoio financeiro concedido, o qual contribuiu para que todos os objetivos propostos fossem cumpridos com tranqüilidade.

À todos que tornaram este trabalho possível (técnicos, funcionários, colegas de trabalho, professores), fazendo tudo que podiam para facilitar meu trabalho e a convivência do dia-a-dia. 


\section{Sumário}

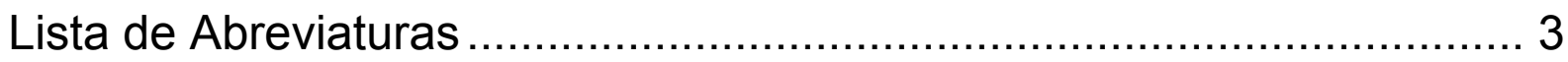

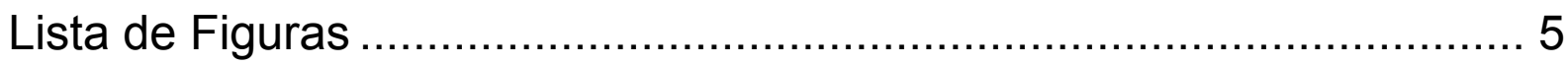

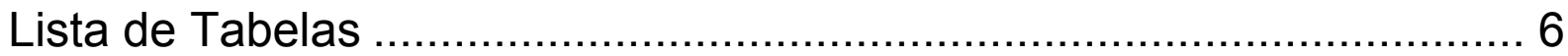

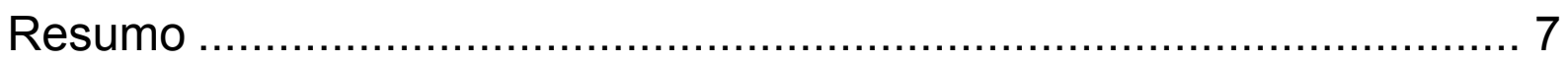

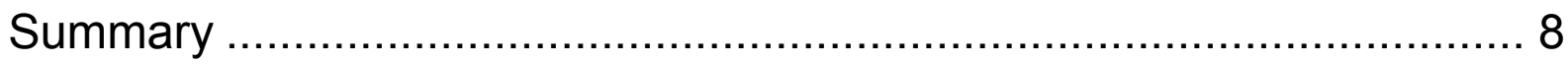

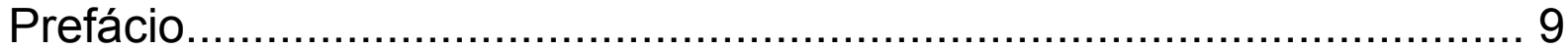

I. INTRODUÇÃO

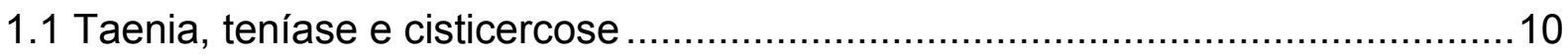

1.2 A distribuição da doença no Brasil e no mundo ...............................................14

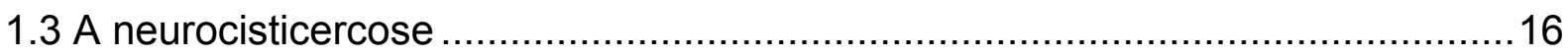

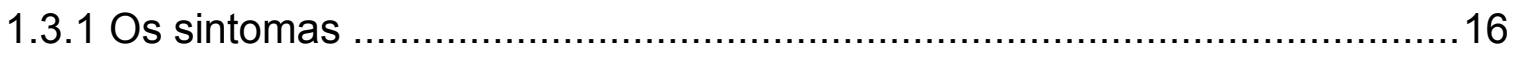

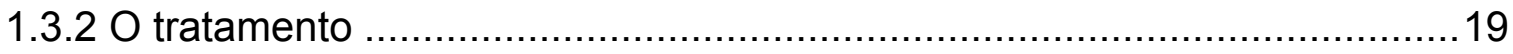

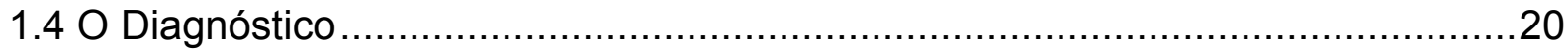

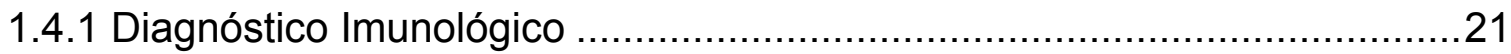

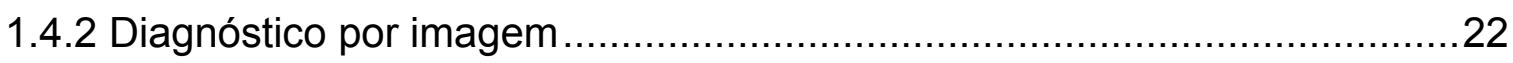

1.4.3 Diagnóstico molecular por deteç̧ão de DNA ……...................................24

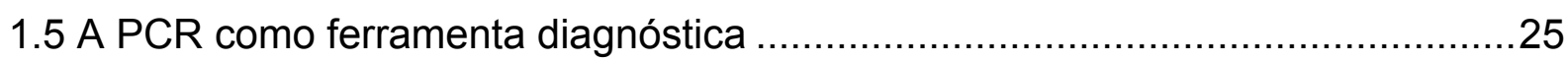

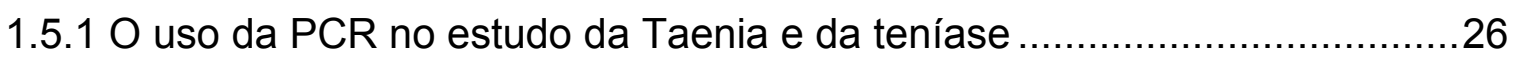

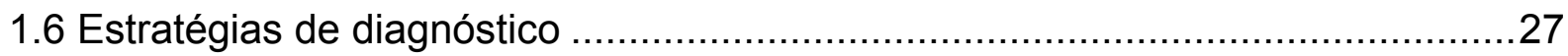

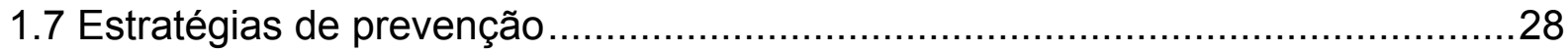

1.7.1 Desenvolvimento de vacinas contra a neurocisticercose .........................28

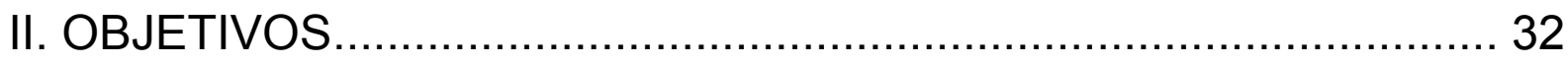

\section{BLOCO I}

III. MATERIAL E MÉTODOS ........................................................ 35

IV. RESULTADOS ............................................................... 40

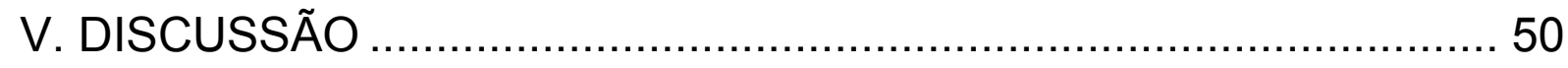


VI. CONCLUSÃO.

63

\section{BLOCO II}

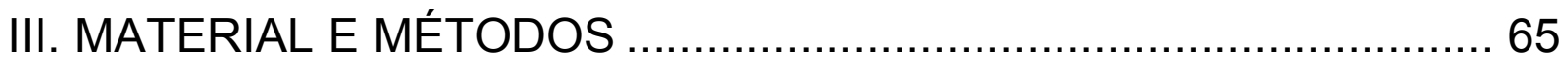

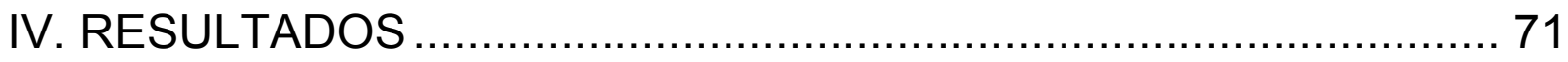

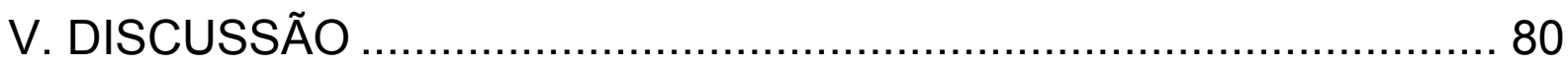

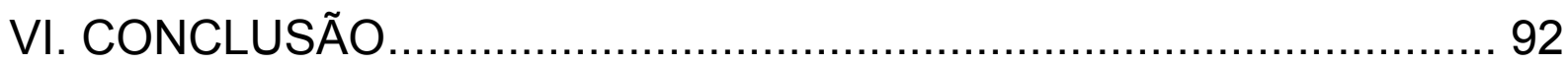

VII. REFERÊNCIAS BIBLIOGRÁFICAS ..................................... 93

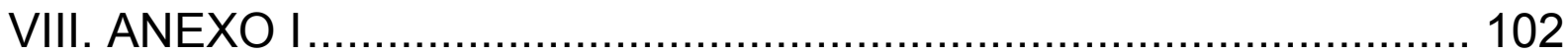




\section{Lista de Abreviaturas}

BLAST - Basic Local Alignment Sequence Tool

cDNA - DNA complementar

dbEST - banco de dados de ESTs

DNA - Desoxiribonucleic Acid (Ácido Desoxirribonucléico)

dNTP - deoxinucleotídeos

EDTA - Ethylenediaminetetracetic acid (Ácido Etileno Diaminotetracético)

EITB - Enzyme-linked Immunoelectrotransfer Blot

ELISA - Enzyme-linked Immunosorbent Assay

EST - Expressed Sequence Tag (Etiquetas de Genes Expressos)

gDNA - DNA genômico

GET - Tampão composto de Glicose 20\%/EDTA 0.5M pH 8.0/Tris-HCl 1M $\mathrm{pH} 7.4$

$\mathrm{HCl}$ - Ácido Clorídrico

IPTG - Isopropyl-beta-D-Thiogalactopyranoside

$\mathbf{K C l}$ - Cloreto de Potássio

LCR - Líquido Cefalorraquiano

$\mathbf{M g C l}_{2}$ - Cloreto de Magnésio

RM - Ressonância Magnética

mRNA - RNA mensageiro

NCC - Neurocisticercose

$\mathrm{Nr}$ - não redundante

nt - Nucleotídeo

ORESTES - Open Reading Frames ESTs (Moldura Aberta de Leitura)

pb - pares de bases

PCR - Polymerase Chain Reaction (Reação em Cadeia da Polimerase)

RNA - Ribonucleic Acid (Ácido Ribonucléico)

rpm - rotações por minuto

SDS - Sodium Dodecyl Sulfate (Dodecil Sulfato de Sódio)

SNC - Sistema Nervoso Central

SNP - Single Nucleotide Polymorphism (Polimorfismo de base única) 
Taq polimerase - Enzima isolada do organismo Termofilus aquaticus resistente a altas temperaturas

TC - Tomografia Computadorizada 


\section{Lista de Figuras}

Figura 1 - Detalhe do verme adulto e dos ovos de Taenia solium

Figura 2 - Diferenças morfológicas entre vermes adultos de $T$. solium e Taenia saginata

Figura 3 - Distribuição geográfica do complexo teníase/cisticercose

Figura 4 - Diagnóstico da neurocisticercose por imagem

Figura 5 - Ciclo da PCR

Figura 6 - Perfil de amplificação do gDNA de $T$. solium

Figura 7 - Especificidade da PCR frente a DNA de outros organismos

Figura 8 - Avaliação da sensibilidade da PCR usando diluições de DNA

Figura 9 - Análise de amostras de líquido cefalorraquiano brutas

Figura 10 - Análise comparativa dos perfis de amplificação obtidos antes e após a purificação do DNA de LCR de pacientes

Figura 11 - Perfil de amplificação das amostras de soro de pacientes infectados pela NCC

Figura 12 - Perfil de digestão do gDNA de T. solium com enzimas de restrição

Figura 13 - Fragmento de DNA de T. solium e suas unidades de repetição

Figura 14 - Perfis de ORESTES

Figura 15 - Vetor utilizado na clonagem das ESTs de $T$. solium

Figura 16 - Seqüência FASTA de uma EST de $T$. solium

Figura 17 - Resultado do BLAST de uma EST de T. solium

Figura 18 - Organismos com maior número de ESTs depositadas no dbEST

Figura 19 - Organismos de interesse parasitológico com maior número de ESTs depositadas no dbEST

Figura 20 - Perfil de análise de uma EST através do programa BLASTX

Figura 21 - Análise de proteína similar à calpaína

Figura 22 - Análise de proteína similar à proteína de choque térmico HSP90

Figura 23 - Análise de proteína similar à cadeia pesada de miosina

Figura 24 - Análise de proteína similar à desmoioquina 


\section{Lista de Tabelas}

Tabela 1 - Enzimas de restrição utilizadas na busca de elementos repetitivos no genoma de $T$. solium

Tabela 2 - Avaliação da PCR como método diagnóstico para a neurocisticercose

Tabela 3 - Minibibliotecas ORESTES produzidas para $T$. solium

Tabela 4 - Resultado de análise parcial das ESTs de $T$. solium produzidas

Tabela 5 - Dados parciais do seqüenciamento das ESTs de $T$. solium 


\section{Resumo}

A neurocisticercose (NCC) é a mais importante parasitose do sistema nervoso central, atingindo um grande número de pessoas, principalmente em países em desenvolvimento. Entre as questões atualmente mais relevantes na NCC, estudamos aqui aspectos relacionados com o diagnóstico da doença e com a determinação de genes transcritos pelo cisticerco, com implicações para o desenvolvimento de vacinas. Os exames de neuroimagem (ressonância magnética e tomografia computadorizada), hoje em dia considerados como os métodos mais precisos no diagnóstico da doença, apresentam custos elevados, normalmente inviáveis nas regiões pobres, as mais seriamente atingidas pela doença. Além disso, os diversos testes imunológicos disponíveis apresentam resultados variáveis, freqüentemente de difícil interpretação, e por vezes com alto número de falso-positivos e/ou falso-negativos. Neste trabalho, nós demonstramos pela primeira vez que o DNA de Taenia solium está presente no líquido cefalorraquiano (LCR) de portadores de NCC, e que sua detecção permite uma nova abordagem diagnóstica baseada na amplificação do DNA. Usando esta abordagem, foi possível estabelecer um diagnóstico preciso para 29/30 (96.7\%) pacientes avaliados, com especificidade de 100\%. No segundo módulo deste trabalho, ampliamos significativamente o conhecimento sobre o transcriptoma da Taenia solium produzindo as primeiras 2.880 ESTs (Expressed Sequence Tags) deste cestódeo. Em nossas análises, encontramos grande quantidade de novos genes deste parasita, aumentando em 11 vezes o conhecimento do transcriptoma deste cestódeo. Os genes aqui revelados incluem candidatos potenciais para desenvolvimento de imunoterapia e novos testes diagnósticos, tanto moleculares quanto imunológicos. Além disto, contribuem para ampliar o conhecimento deste importante parasita, o que deverá ajudar a fomentar as pesquisas relacionadas à teníase e à neurocisticercose. 


\section{Summary}

Neurocysticercosis is the most frequent parasitic infection of the central nervous system, mainly in developing countries. High costs of magnetic resonance images (nowadays the most accurate method of diagnosis) may be prohibitive in these regions and the interpretation of the multiple immunologic tests available is often difficult. We demonstrate in this work that Taenia solium DNA is present in the cerebrospinal fluid (CSF) of patients and enabled the correct diagnosis of $29 / 30$ patients $(96.7 \%)$ with $100 \%$ specificity through the PCR methodology. The presence of parasite DNA in the CSF of patients may have important consequences over the diagnosis of this important disease. Besides, we enlarge significant the knowledge about Taenia's transcriptome producing the first 2880 ESTs (Expressed Sequence Tags) of Taenia solium cysticerci. We were able to found at least seven new important genes that may be an important role in a battle against neurocysticercosis because through them it is possible identify considerable aspects of this disease, even though establishing other and efficient strategies of prevention, founding new antigens to improve the immunodiagnosis or building a vaccine to protect the hosts that carry on this important parasite. 


\section{Prefácio}

Neste trabalho buscamos contribuir para o avanço de duas questões de grande importância para a neurocisticercose humana: seu Diagnóstico (módulo 1) e a Descoberta de novos genes (módulo 2).

Para facilitar a leitura e a organização dos dados aqui apresentados, estruturamos este trabalho com uma única introdução, seguida de blocos específicos para cada um dos módulos, cada um contendo materiais e métodos, resultados e discussão. 


\section{INTRODUÇÃO}

\subsection{Taenia, teníase e cisticercose}

Cestódeos (do grego kestos, 'fita' e eidos, 'semelhante') são vermes platelmintos, de corpo alongado em forma de fita que podem medir de alguns milímetros a muitos metros de comprimento. As espécies de maior interesse médico são: Taenia solium, Taenia saginata e Echinococcus granulosus, mas outras espécies como a Taenia crassiceps (parasita de raposas) e a Taenia asiática também têm despertado a atenção dos pesquisadores.

A $T$. solium é o agente causador de duas importantes infecções conhecidas como teníase e cisticercose, doenças que atingem uma parcela significativa da população mundial, embora ainda sejam consideradas doenças típicas de países em desenvolvimento. Essas infecções ocorrem por mecanismos distintos, através da ingestão de carne contaminada por cisticercos, o que ocasiona a teníase ou pela ingestão direta de ovos do parasita (por contaminação de água, comida ou autoinfecção), o que leva à cisticercose. Cabe notar que a teníase pode ser causada pelas espécies $T$. solium e $T$. saginata, enquanto que a cisticercose é causada apenas pela $T$. solium. Detalhes do verme adulto e dos ovos da $T$. solium são apresentados na Figura 1.

Apenas os seres humanos podem atuar como hospedeiros definitivos da $T$. solium, albergando os vermes adultos (teníase), mas também podem atuar, juntamente com os suínos, como hospedeiros intermediários (cisticercose).

Figura 1 - Parasita T. solium. Em A, micrografia eletrônica de varredura mostrando em detalhe o rostro e o escólex de um verme adulto (fonte: http://www. les-autres.biz/archives/archive-122002.html); B, um dos ovos do parasita (fonte: http://www2.uol.com.br/cienciahoje/chdia/n174.htm). 
A

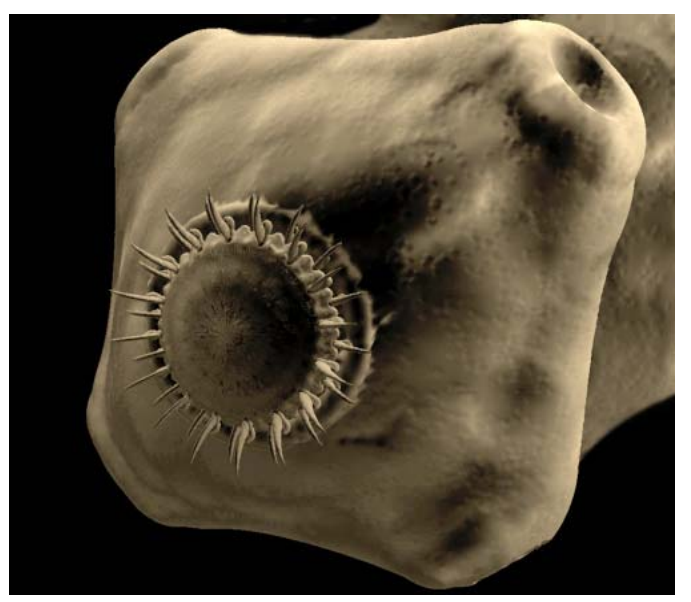

B

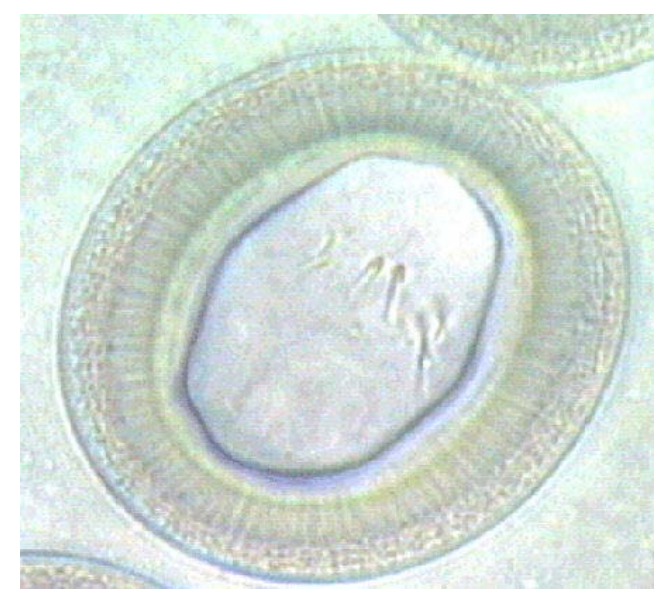

A $T$. solium, cestódeo de maior importância clínica em razão de sua patogenicidade, apresenta um complexo ciclo biológico. O verme é hermafrodita e quando suas proglotes maduras se rompem no intestino, liberam, cada uma, cerca de 50.000 a 60.000 ovos férteis, que podem permanecer viáveis por até sete anos na água, no solo e na vegetação (Garcia \& Del Brutto, 2000; Carpio, 2002). Cada verme pode eliminar até 300.000 ovos por dia, os quais são capazes de sobreviver em condições extremas de temperatura e dessecação, embora umidade e baixas temperaturas (ao redor de $10^{\circ} \mathrm{C}$ ) favoreçam a sua manutenção e viabilidade (Carpio, 2002).

A teníase é popularmente conhecida como "solitária", pois um indivíduo raramente apresenta mais de um verme adulto em seu intestino. Esta doença ocorre somente em hospedeiros humanos, após a ingestão de carne mal cozida contaminada com cisticercos. Neste caso, tanto a $T$. solium (carne suína) quanto a $T$. saginata (carne bovina), podem causar a infecção. Esses dois vermes são bastante semelhantes, porém diferem em algumas características particulares. A T. solium possui um escólex "armado", ou seja, com quatro ventosas e uma coroa dupla de ganchos ("rostelo"), além de um estreito pescoço e um grande estróbilo medindo de 2-4 metros, o qual possui várias centenas de proglotes, enquanto que $T$. saginata apresenta um escólex "desarmado", com ventosas desprovidas de ganchos e um estróbilo que pode alcançar 8 metros (Neves, 2000). Deste modo, a parte superior do verme ("cabeça") é denominada escólex enquanto que o 
estróbilo é a porção correspondente ao tronco, onde encontramos as proglotes (também chamadas de "anéis") imaturas, maduras e grávidas (Figura 2).

Figura 2- Diferenças morfológicas entre vermes adultos de $T$. solium (A) e $T$. saginata (B). Em A, podemos observar a coroa de ganchos presente em $T$. solium (seta). Em B, os ganchos estão ausentes. É possível observar a alta semelhança entre os ovos e a sutil diferença entre as proglotes, o que justifica a grande dificuldade em se distinguir morfologicamente os dois parasitas.

Fonte: www.ratsteachmicro.com/Cestodes/COE_CAI_Review_Notes_Cestodes.html

A

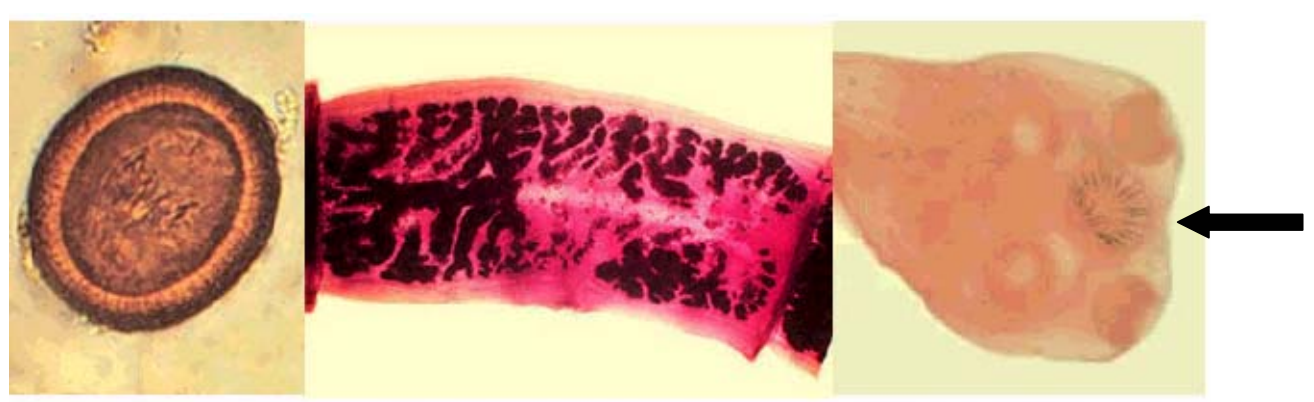

B

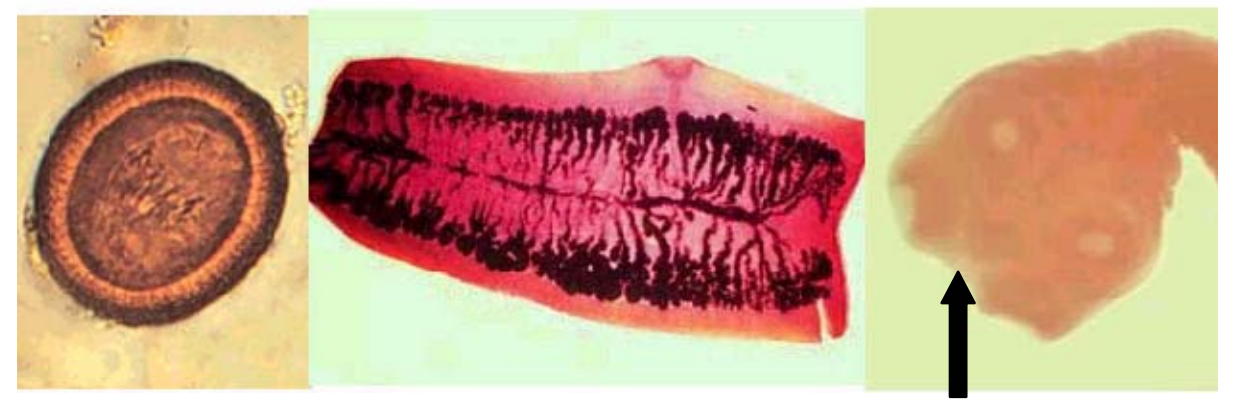

Através dos ganchos e das ventosas o verme se fixa firmemente ao epitélio intestinal humano. Em geral, após cerca de dois meses depois da infecção já é possível encontrar proglotes maduras ("grávidas") que começam a se destacar e a serem excretadas junto com as fezes.

Por ser uma parasitose intestinal, a teníase pode causar retardo no crescimento e no desenvolvimento das crianças, além de diminuir a produtividade dos adultos. Os sintomas mais freqüentes são dores abdominais, náuseas, vômitos, debilidade, perda de peso, flatulência, diarréia e constipação (Song et al., 
2004). Quando não devidamente tratada, a teníase pode levar à obstrução do apêndice, colédoco e ducto pancreático, em função do crescimento excessivo do parasita.

A teníase ocorre quando há ingestão de cisticercos vivos, que podem ser encontrados em carnes cruas ou mal cozidas. No interior do intestino, o cisticerco se evagina dando origem ao verme adulto. A teníase, normalmente, é facilmente identificada, pois o indivíduo elimina proglotes do verme adulto em suas fezes. $\mathrm{O}$ tratamento é simples, sendo feito com a administração de anti-helmínticos, que em geral são bastante eficazes. Medidas de saneamento básico e educação sanitária são coadjuvantes de extrema importância para a prevenção da doença e as re-infecções.

A cisticercose é muito comum principalmente em locais cujas condições sanitárias são precárias, onde as fezes humanas são depositadas inadequadamente podendo servir de alimento para porcos e outros animais. Quando as fezes se encontram contaminadas por ovos de $T$. solium, os embriões são liberados pela ação dos fluidos e ácidos gastrointestinais. Tais oncosferas atravessam ativamente a parede do intestino, caem na corrente sangüínea e podem se instalar em qualquer região do corpo (musculatura, coração e até mesmo no globo ocular). Nestes locais, os cisticercos se desenvolvem estabelecendo a infecção (Garcia \& Del Brutto, 2000; Carpio, 2002).

As manifestações clínicas da cisticercose dependem do tipo morfológico, número e localização das larvas que infectaram o indivíduo, da fase de desenvolvimento dos cisticercos e da resposta imunológica do hospedeiro. As complicações podem levar a uma deficiência visual, distúrbios psiquiátricos, crises epiléticas e a um aumento da pressão intracraniana, sendo esta a principal responsável pela alta letalidade da doença (Del Brutto \& Sotelo, 1988; Barry \& Kaldjian, 1993; Pardini et al., 2001; Garcia et al., 2003).

Os cistos podem ser classificados em três categorias: cisto vesicular, onde o parasita encontra-se envolto por uma membrana preenchida com um fluido transparente e cuja presença causa poucas reações inflamatórias ao redor dos tecidos; cisto coloidal, estado no qual o parasita encontra-se em processo de degeneração, caracterizado pela presença de uma reação inflamatória, e cisto 
calcificado, quando o parasita está morto e o cisto se encontra mineralizado (Fleury et al., 2004).

Como dito anteriormente, os cistos podem ser encontrados em qualquer parte do corpo humano, mas o local mais freqüente e de importância clínica mais relevante da instalação de cisticercos é no sistema nervoso central (SNC), levando à neurocisticercose (García et al., 2003). Esta, atualmente, é considerada a principal responsável pelos freqüentes episódios de crises epilépticas de início tardio nos países em desenvolvimento.

\subsection{A distribuição da doença no Brasil e no mundo}

Estima-se que cerca de 4 milhões de pessoas no mundo apresentam a forma adulta do parasita e que aproximadamente 50 milhões de pessoas sejam portadoras de cisticercos (CDC, 1992; Tsang \& Wilson, 1995; Cantú \& Barinagarrementeria, 1996). Não obstante a essa estatística, mais de 50.000 pessoas morrem todos os anos devido a neurocisticercose (Lawrence, 2002; Ito \& Craig, 2003), enquanto um número muito maior de pacientes apresenta outros tipos de danos neurológicos. Em tempos de globalização, o aumento considerável dos fluxos migratórios e do turismo faz com que esta doença se alastre (Chapman et al., 1995; Carpio, 2002), deixando suas fronteiras anteriormente restritas a países de terceiro mundo e podendo atingir as mais diversas regiões do planeta.

Através de métodos diagnósticos imunológicos foi possível demonstrar que de 8 a 12\% das pessoas que vivem em áreas endêmicas possuem anticorpos contra T. solium, (Carpio, 2002), o que oferece uma medida indireta de sua alta prevalência.

Estudos recentes realizados no México mostraram que a neurocisticercose (NCC) é a terceira maior causa de internação em hospitais neurológicos, a causa mais comum de epilepsia de início tardio e o diagnóstico final em $10 \%$ de todas as autópsias realizadas em hospitais neurológicos; quando estas estatísticas de autópsias se referem a hospitais gerais, ficam em torno de 1-2\% (Fleury et al., 2004).

A NCC deixou de ser considerada como uma doença típica de países em desenvolvimento devido à sua alta e ampla incidência, podendo ser encontrada 
inclusive em países desenvolvidos. Nos Estados Unidos, mais de mil casos são registrados por ano, principalmente na região Sudeste, onde a imigração é bem significativa (Jamison et al., www. utmb.edu/pedi/Residency/Neurocyst.ppt). A distribuição geográfica do complexo teníase/cisticercose é ampla, e pode ser vista na Figura 3, a seguir:

Figura 3- Estimativa da distribuição geográfica do complexo teníase/cisticercose.

As áreas marcadas em vermelho representam regiões endêmicas, de alta prevalência. As áreas alaranjadas indicam prevalência moderada, enquanto que as representadas em bege indicam áreas onde os casos registrados foram relacionados à migração. Em branco estão representados os locais onde não se tem informação à respeito da incidência da doença. Os quadrados escuros indicam áreas endêmicas em território norte-americano.

Fonte: Carpio, 2002.

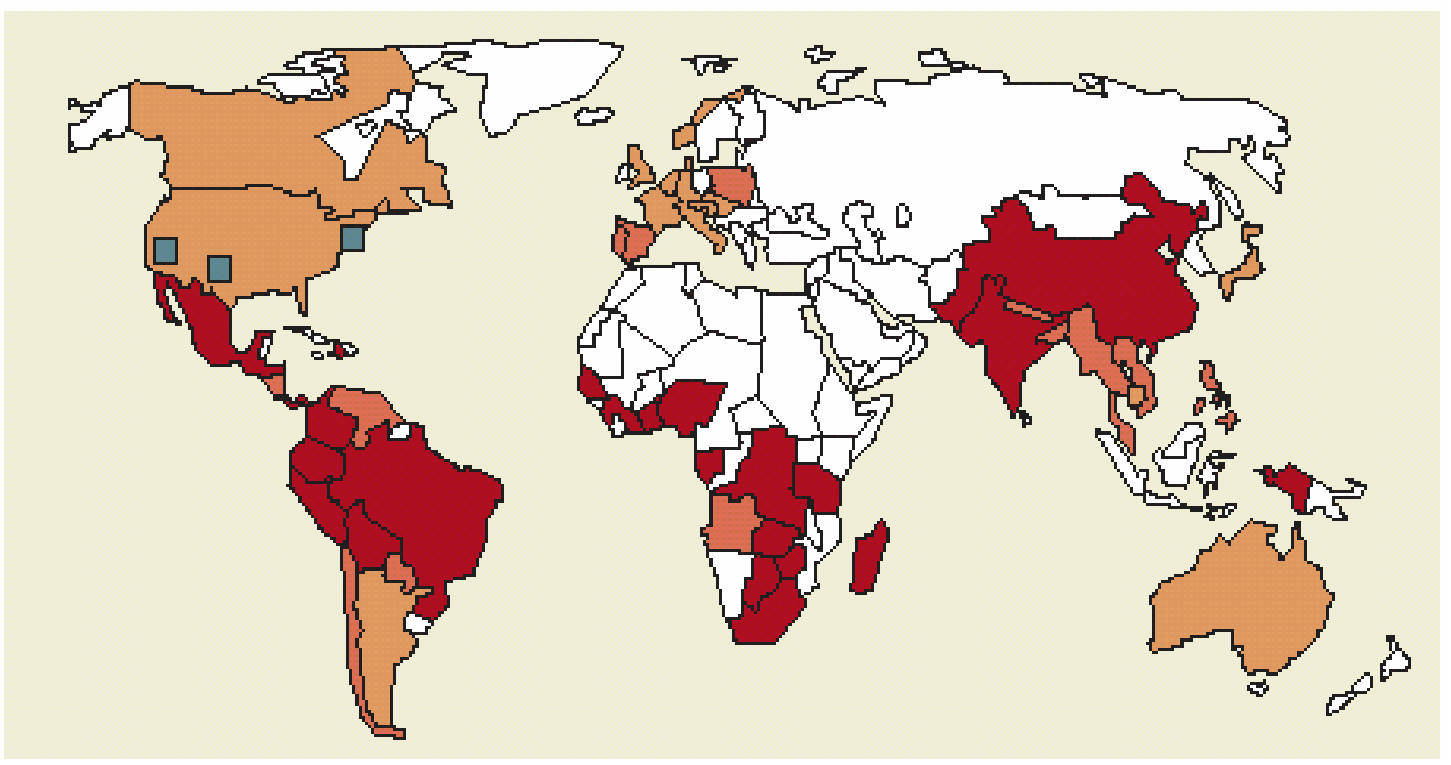

No Brasil, importantes áreas de criação suína se concentram no sul do país, abrangendo os Estados do Paraná, Santa Catarina e Rio Grande do Sul, onde se localizam algumas das maiores empresas produtoras e beneficiadoras de carne suína. A realização de tomografia computadorizada (TC) em diferentes 
regiões do Estado de Santa Catarina revelou uma prevalência global da NCC de $1,2 \%$ dentre mais de 143.000 exames realizados. Observou-se ainda uma clara distinção na prevalência da doença entre as regiões estudadas, sendo a maior prevalência (30\%) encontrada na região do planalto catarinense (SES-SC, 1995). Este nível de prevalência demonstra a seriedade do problema, porém, a NCC é altamente negligenciada e sua incidência é subestimada devido à falta de métodos confiáveis para detectar e/ou confirmar a NCC (Ito \& Craig, 2003).

\subsection{A neurocisticercose}

A manifestação clínica mais importante da cisticercose resulta da presença da larva no SNC causando a NCC. Tal doença tem sido mundialmente reconhecida como uma das principais causas de doenças neurológicas (ILAE, 1994; Tsang \& Wilson, 1995, Ito et al., 2003) e normalmente é classificada de acordo com o estágio em que se encontram os cistos alojados no cérebro. Diz-se que a infecção é ativa quando os cistos estão vivos, enquanto que a infecção inativa se refere à fase onde os cistos já estão calcificados. De acordo com a sua localização no cérebro, os cistos podem ser classificados como intraparenquimais e extraparenquimais.

Os cistos intraparenquimais geralmente têm um curso mais benigno, ao contrário dos cistos de localização extraparenquimal (subaracnóideo, ventricular, cisternal), que geralmente levam a um pior prognóstico. Esse pior prognóstico é ocasionado pelo processo de crescimento e infiltração do cisticerco, ocasionando uma hidrocefalia que acaba por levar a alterações no fluido cerebroespinhal, pleocitose e uma elevada concentração de proteínas (García et al., 2003).

\subsubsection{Os sintomas}

Os pacientes com NCC normalmente apresentam uma variedade de manifestações clínicas que, na sua maioria, são inespecíficas (Medina \& Christopher, 2002). Os sintomas podem incluir dores de cabeça, convulsões, perda de visão ou de capacidade motriz, ocasionando graves seqüelas cerebrais, que podem levar a crises epiléticas, hidrocefalia, demência, hipertensão intracraniana e até mesmo à morte. Esta multiplicidade de sintomas é um dos 
fatores que dificulta o diagnóstico preciso da doença. Sabe-se hoje que a presença de cistos vivos é o maior fator de risco para a presença de crises epiléticas (Lawrence, 2002), o que torna fundamental o diagnóstico da infecção ativa.

Os cisticercos causam essa variedade de sintomas devido ao seu efeito de massa ou devido ao bloqueio da circulação do fluido cerebroespinhal ou líquido cefalorraquiano (LCR), embora a maioria dos sintomas esteja diretamente associada ao processo inflamatório que acompanha a sua degeneração (Garcia et al., 2003).

O líquido cefalorraquiano juntamente com as membranas cerebroespinhais são os componentes do nosso sistema craniossacral. Este sistema, o qual tem a função de envolver e proteger o cérebro e a medula, se estende desde os ossos do crânio, face e boca até o sacro, e é de vital importância para o perfeito desenvolvimento e desempenho do cérebro e da medula. Um desequilíbrio ou restrição no sistema pode ocasionar vários problemas sensoriais, motores ou neurológicos. O LCR é produzido e absorvido constantemente (adultos saudáveis processam e repõem cerca de 600 mililitros de LCR por dia), e qualquer estrutura ou processo patológico que interfira no bom andamento deste processo pode levar a alterações da pressão intracraniana, que podem ter conseqüências desastrosas.

A interrupção da circulação do LCR é ocasionada por diversos fatores, entre eles está a simples presença do cisto, uma possível inflamação ependimal ou até mesmo uma fibrose residual. Além disso, eventualmente, os cistos podem sofrer um processo de crescimento exagerado, semelhante a um processo de proliferação tumoral, que pode levar à compressão adjacente de algumas estruturas cerebrais, com deficiências localizadas e até mesmo à hipertensão intracraniana. Em alguns casos, podem também ser evidenciadas algumas lesões motoras, que podem ser derivadas de um edema secundário resultante do processo de degeneração dos cistos ou de uma complicação da NCC (Garcia et al., 2003).

As crises epiléticas são as manifestações clínicas mais freqüentes na NCC, podendo ser observadas em cerca de $50 \%$ a $80 \%$ dos casos sintomáticos, 
particularmente em pacientes que apresentam um comprometimento do parênquima cerebral (Arseni \& Cristescu, 1972; López-Hernandez \& Garaizar, 1982; Sotelo et al., 1985; Del Brutto et al., 1992). Um dado preocupante é que a maioria destes pacientes apresenta exames neurológicos normais, o que dificulta muito o diagnóstico preciso e precoce desta doença.

Um estudo feito no sudeste da Índia mostrou uma forte associação entre NCC e crises epiléticas em $51 \%$ dos pacientes. Paralelamente, um outro estudo realizado em Honduras mostrou que, de todos os diagnósticos confirmados para NCC, as crises epiléticas estavam presentes como principal característica em $52 \%$ dos casos (WHO, 2002).

Em regiões onde a cisticercose é endêmica, a presença de crises epiléticas em pessoas maiores de 25 anos (epilepsia de início tardio) é altamente sugestiva de NCC (Del Brutto \& Noboa, 1991). A maioria desses pacientes apresenta um exame neurológico normal, apesar da presença das crises generalizadas (Del Brutto et al., 1992); por isso, estudos de neuroimagem são preconizados para todos os pacientes com epilepsia de início tardio, com o objetivo de descartar ou confirmar a suspeita clínica da NCC (Del Brutto, 1994).

Além de seus sintomas clínicos diretos, a NCC pode levar ao desenvolvimento de outras doenças, tendo, inclusive, já sido demonstrada uma associação desta doença com o surgimento de tumores no cérebro e alterações hematológicas malignas em alguns pacientes (Herrera et al., 2000). Esta importante associação foi feita em estudos do tipo caso-controle que mostraram uma relevante parcela de pacientes com NCC entre os pacientes que possuíam glioma (Del Brutto et al., 1997).

A inespecificidade da sintomatologia da NCC é decorrente das diferentes condições em que o cisticerco pode se apresentar no cérebro humano. Em alguns pacientes os cisticercos podem ser destruídos e/ou calcificados sem produzirem qualquer tipo de sintoma, enquanto que em outros casos, os cistos podem se degenerar, induzindo um processo inflamatório, ou ainda, podem permanecer vivos (vesiculares) e viáveis por muitos anos. 


\subsubsection{O tratamento}

Recentemente tem havido um avanço nas pesquisas voltadas ao tratamento da NCC, no entanto, algumas questões relevantes permanecem sem resposta. A maior delas se refere aos mecanismos que sublinham as heterogeneidades clínica, radiológica e inflamatória da doença. Fatores associados ao hospedeiro como gênero, idade e composição genética, bem como fatores sociais, nível de exposição ao parasita e até mesmo sua diversidade genética, são fatores que podem estar envolvidos na heterogeneidade da NCC (Fleury et al., 2003). No entanto, faz-se necessário um maior número de estudos para esclarecer o verdadeiro papel de cada uma destas variáveis. Em linhas gerais, acredita-se que os tratamentos hoje disponíveis são muito controversos e devam ser aplicados individualmente, de acordo com o histórico de cada paciente (Alvarez Rodriguez et al., 2004).

Neste contexto, Fleury et al. (2004) observaram que a grande variedade existente no número, estágio, localização e nível de inflamação das lesões causadas pelo parasita está fortemente associada à heterogeneidade dos sintomas da NCC. O aumento do número de vesículas dos cisticercos e uma diminuição no número de cisticercos que são degenerados conforme o indivíduo afetado vai envelhecendo, bem como a proeminência desta inflamação em mulheres adultas, sugerem que fatores imuno-endócrinos possam ter um papel fundamental na suscetibilidade e na patogenicidade da doença.

Desta forma, diante de seu pleomorfismo clínico, não é possível que um só tipo de abordagem seja útil em todos os casos (González et al., 1999). Para tanto, a caracterização precisa da enfermidade, bem como a localização das lesões é de fundamental importância para a aplicação de um tratamento adequado (Del Brutto, 1993).

Algumas drogas cestocidas como o praziquantel e o albendazol têm se mostrado eficaz na terapêutica etiológica da NCC. O praziquantel vem sendo utilizado no tratamento da NCC desde 1978. Até então, a única maneira viável de se tratar a doença era através de uma cirurgia para excisão dos cistos (nem sempre possível) ou administração de esteróides para diminuir o processo inflamatório (Garcia et al., 2003). 
Estudos indicaram o desaparecimento de $60 \%$ a $70 \%$ dos cisticercos parenquimatosos após 15 dias de tratamento (Sotelo et al., 1985). Já o albendazol foi capaz de destruir de $75 \%$ a $90 \%$ dos cisticercos parenquimatosos (Takayanagui \& Jardim, 1992). Apesar disso, ainda há questionamentos sobre a eficácia dessas drogas, pois quando a eliminação dos cisticercos é apenas parcial, seqüelas graves da NCC ainda podem permanecer.

Uma estratégia promissora para diminuir a incidência da cisticercose é a identificação e o tratamento dos indivíduos portadores do verme adulto (Chapman et al., 1995). É extremamente importante o reconhecimento dos fatores de risco, pois é preciso saber se o indivíduo morou ou esteve em contato com zonas endêmicas, com pessoas ou alimentos contaminados.

Dessa forma, levando-se em consideração as incertezas quanto aos benefícios, a alta falibilidade (alguns pacientes morreram durante o tratamento com as drogas), os riscos da terapêutica farmacológica e as altas taxas de reinfecção, a eficiente solução para a NCC está colocada primordialmente nas medidas de prevenção da infestação e em estudos que permitam o desenvolvimento de um outro método diagnóstico e/ou imunoterápico que seja ao mesmo tempo sensível, eficiente e, principalmente, acessível à população.

\subsection{O Diagnóstico}

A NCC é uma doença relativamente comum, mas seu diagnóstico clínico pode ser um desafio, pois ela pode ser confundida com outras doenças devido a inespecificidade dos seus sintomas.

Atualmente, a única ferramenta realmente confiável para o diagnóstico da NCC é a confirmação patológica através de biópsia ou autópsia, procedimentos que possuem limitações óbvias (Carpio, 2002).

Há ainda que se considerar que o alto custo dos exames de comprovação desta doença impede que a maioria da população afetada tenha acesso ao diagnóstico correto. Para se ter uma idéia, só os gastos anuais do sistema de saúde brasileiro decorrentes do atendimento médico-hospitalar a pacientes que apresentam NCC chegam à cerca de 85 milhões de dólares (Pal et al., 2000). 
Tendo em vista a dificuldade em se detectar o parasita e o quadro clínico apresentado pelos pacientes, que na maioria das vezes é pouco sugestivo, a doença tem instigado pesquisadores do mundo todo que buscam alternativas diagnósticas mais eficientes.

\subsubsection{Diagnóstico Imunológico}

O ELISA (Enzyme-linked Immunosorbent Assay) e o EITB (Enzyme-linked Immunoelectrotransfer Blot) são os testes imunológicos mais freqüentemente usados no diagnóstico da cisticercose humana. O ELISA é mais usado por ser um teste mais simples e barato, porém, pode apresentar resultados falso-positivos com grande freqüência e falso-negativos, com uma sensibilidade de $50 \%$ e uma especificidade de 65\% para NCC (Carpio, 2002; Garcia et al., 2003). Além disso, por vezes o teste ELISA é incapaz de distinguir entre as duas espécies mais importantes de Taenia, bem como distinguir ambas de outros helmintos aparentados (Allan et al., 1990; Machnicka, 1996). Mesmo assim, o teste ainda é muito usado e diversos grupos vêm buscando desenvolver antígenos que ofereçam maior sensibilidade e maior especificidade.

Antígenos anticisticercos têm sido freqüentemente usados para detectar anticorpos permitindo o imunodiagnóstico da NCC. Num caso específico, extrato de membrana de Cysticercus fasciolaris, estágio larval de Taenia taeniformis foi usado no teste ELISA, apresentando resultados relevantes; dentre eles, o encontro de anticorpos contra os cisticercos no soro de pacientes com NCC (anticorpos lgG e $\lg \mathrm{M}$ ). O teste demonstrou uma sensibilidade de $93.54 \%$ e uma especificidade de $84.2 \%$ (Husain et al., 2001).

Pardini et al. (2002), utilizaram extratos antigênicos de T. crassiceps para detecção de anticorpos anticisticercos de $T$. solium por ELISA, exibindo sensibilidade e especificidade iguais a $100 \%$. Os extratos antigênicos foram obtidos do fluido vesicular de cisticercos de $T$. crassiceps e de frações purificadas por cromatografia de afinidade com lectina concanavalina $A$.

O EITB (Enzyme-linked Immunoelectrotransfer Blot) é considerado por alguns autores como o melhor teste imuno-diagnóstico disponível atualmente (Carpio, 2002) e, ainda assim, apresenta algumas limitações importantes. Essa 
ferramenta diagnóstica é muito pouco eficiente em detectar a infecção em pacientes que apresentam poucos ou apenas um único cisto no cérebro. Além disso, o teste pode apresentar um resultado positivo para NCC quando na verdade o paciente possui apenas uma teníase (Garcia et al., 1995; Carpio, 2002). Diante disso, a análise dos resultados deve ser cautelosa, pois um resultado negativo não exclui o diagnóstico da NCC, bem como um resultado positivo não representa a presença de cistos no cérebro [dois terços dos indivíduos soro-positivos não apresentaram lesões identificáveis quando submetidos à TC (Carpio, 2002)]. Essas limitações, comuns em testes baseados na detecção de anticorpos, podem indicar que o paciente tenha tido uma exposição prévia ao parasita ou a seus antígenos e não necessariamente que o indivíduo tenha a infecção ativa, pois é comum encontrarmos anticorpos no organismo do paciente mesmo após o controle da infecção. Além disso, o EITB apresenta alto custo, o que reduz a sua disponibilidade.

Segundo estudos realizados por Sanchez et al. (1999), o EITB apresentou $50 \%$ de sensibilidade no soro e $63 \%$ no LCR. Além disto, um estudo numa população rural em Honduras mostrou que uma parcela significante de pessoas assintomáticas que tinham um resultado positivo para o EITB tinham tomografia computadorizada (TC) normais e não estavam infectadas por Taenia (Sanchez et al., 1999).

Um número significativo de outros testes imunológicos vem sendo avaliado no diagnóstico da cisticercose, incluindo fixação do complemento, método de hemaglutinação indireto e imunoeletroforese. No entanto, os dados ainda são muito escassos e a eficiência ainda é muito questionável, deixando o diagnóstico vulnerável a uma análise subjetiva de um experiente especialista (Quintana et al., 2001).

\subsubsection{Diagnóstico por imagem}

Uma outra forma de se diagnosticar a NCC é através de dados de neuroimagem (RM - Ressonância Magnética - e TC - Tomografia Computadorizada), pois dessa forma é possível determinar o número, estágio, localização e tamanho dos parasitas, bem como a resposta inflamatória do 
hospedeiro. Atualmente, o diagnóstico por imagem é tido como "gold standard" (Carpio, 2002), mas mesmo assim, apresenta limitações consideráveis.

A RM é mais eficiente em evidenciar cistos intraventriculares e subaracnóideos, enquanto que a TC é mais eficaz na identificação de lesões inativas ou calcificadas. A TC é mais acessível e mais barata do que a RM, mas não é capaz de evidenciar todas as lesões, apresentando falhas em mais de $60 \%$ dos casos (Garcia et al., 2003), embora seja mais eficiente em detectar cistos já calcificados (Carpio, 2002). A RM é bastante eficaz em identificar o número, a localização e o estágio de evolução do parasita, mas por outro lado, possui um altíssimo custo e por esse motivo é menos acessível e/ou disponível (Garcia et al., 2003).

Embora consideradas como as mais eficientes maneiras de se diagnosticar a presença de cistos, técnicas de neuroimagem são baseadas em "cortes" virtuais do cérebro, o que justifica alguns casos (ainda que poucos) não confirmados por estes métodos, pois pode acontecer do cisto estar localizado numa região que não foi avaliada pela neuroimagem, sugerindo a ausência de cistos e comprometendo o correto diagnóstico.

A seguir podem ser vistas três imagens, que evidenciam diferentes estágios em que o cisticerco pode ser encontrado no cérebro humano.

Figura 4 - Diagnóstico por imagem. Em A, diagnóstico obtido por RM do lobo temporal direito. Em B, diagnóstico obtido por TC da mesma região cerebral. Em $\mathbf{A}$ e $\mathbf{B}$, os círculos em destaque evidenciam um cisto ativo. Em $\mathbf{C}$, a seta evidencia um cisto calcificado.

Fonte: www.utmb.edu/pedi/Residency/Neurocyst.ppt 

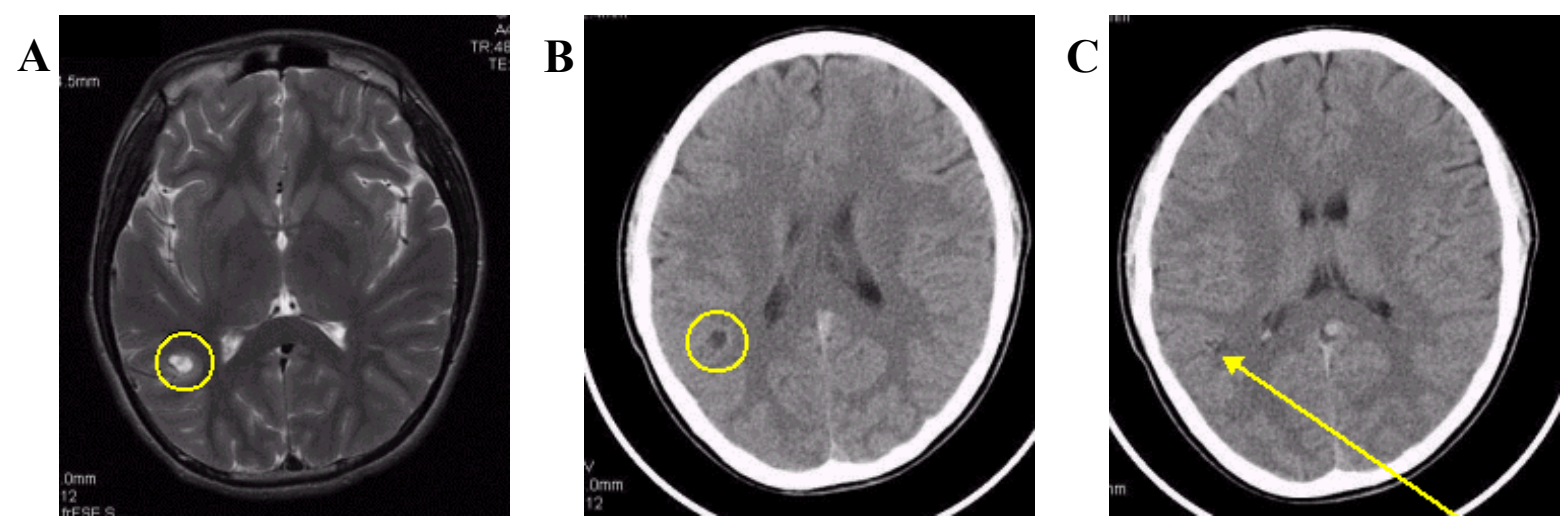

\subsubsection{Diagnóstico molecular por detecção de DNA}

A gravidade da NCC está diretamente relacionada à localização do parasita nos ventrículos cerebrais ou cisternas basais, bloqueando a circulação do LCR, o que pode ser causado pela simples presença do parasita, por uma inflamação ependimal ou por uma fibrose tecidual. Ocasionalmente os cistos podem crescer tanto que chegam a se assemelhar a uma massa tumoral, causando compressão às estruturas cerebrais (Garcia et al., 2003). Todos estes fatores facilitam a liberação de moléculas do parasita na corrente sangüínea e em fluidos dos pacientes, como por exemplo, na circulação sanguínea e no LCR. Prova disso é a variedade de métodos imunológicos capazes de encontrar antígenos presentes no LCR de pacientes acometidos por NCC, enfatizando a probabilidade de se detectar componentes genéticos e até mesmo celulares nos fluidos de pessoas infectadas (Pardini et al., 2001; Bueno et al., 2000). Do mesmo modo que os antígenos são liberados, é possível que células do parasita venham a se romper, liberando seu conteúdo, inclusive seu DNA.

A evolução de testes de DNA para o diagnóstico de doenças infectocontagiosas tem sido acelerada. Atualmente, encontramos mais de 80 mil artigos relacionando uma técnica de amplificação de DNA (PCR - Polymerase Chain Reaction) e a palavra "diagnosis" (PubMed, 07 de Abril de 2005). No entanto, diferentemente do que ocorre para centenas de outras situações patológicas, ainda existem poucos trabalhos que fazem menção ao diagnóstico de infecção por Taenia utilizando técnicas de amplificação de DNA. Nenhum destes artigos 
demonstrou o diagnóstico da NCC pela detecção de DNA do parasita, nem sequer demonstrou a presença de DNA do parasita em fluidos biológicos.

\subsection{A PCR como ferramenta diagnóstica}

A técnica de PCR (Polymerase Chain Reaction) revolucionou a biologia molecular, por permitir a amplificação e a detecção do DNA com extrema facilidade, rapidez e baixo custo. A PCR foi desenvolvida por Kary B. Mullis em 1989; sua descoberta representou um avanço científico tão considerável que rendeu ao seu inventor o Prêmio Nobel de Química poucos anos depois, em 1993.

Esta técnica consiste basicamente em três etapas: 1) Desnaturação do DNA: a temperatura dos tubos de reação é elevada para $94^{\circ}-96^{\circ} \mathrm{C}$ para que a fita dupla da molécula de DNA seja separada em duas fitas simples; 2) Anelamento dos iniciadores: a temperatura é reduzida (para algo entre $37^{\circ}-72^{\circ} \mathrm{C}$ ) para que os iniciadores (oligonucleotídeos sintéticos de seqüência conhecida) se liguem às regiões complementares do DNA alvo, marcando o ponto de partida de amplificação de cada nova fita a ser sintetizada; 3) Extensão dos iniciadores: a temperatura é elevada novamente para cerca de $72^{\circ} \mathrm{C}$ para que uma DNA polimerase termoestável possa sintetizar as novas fitas, reconhecendo a extremidade 3' dos iniciadores, ligada ao DNA molde e adicionando os nucleotídeos de modo a complementar à fita molde, produzindo uma nova fita de DNA. Este ciclo é repetido cerca de 30 a 50 vezes, produzindo novas cópias de forma exponencial. Ao final de 35 ciclos são geradas aproximadamente 68 bilhões de cópias do fragmento de estudo, a partir de uma única cópia inicial (Figura 5).

Os números indicam a sensibilidade desta técnica, fazendo com que ela venha sendo usada no diagnóstico de várias doenças infecto-contagiosas com grande sucesso. Além disto, em vista dos métodos hoje disponíveis para o diagnóstico da NCC, a PCR apresenta algumas vantagens por ser uma técnica rápida (os resultados podem ser liberados em apenas 6 horas), econômica (cerca de $\mathrm{R} \$ 0,50$ por reação) e extremamente sensível. O maior investimento para implementação desta metodologia estaria na obtenção dos termocicladores $(\mathrm{R} \$ 15000,00$ - $R \$ 20000,00)$, mas que ainda assim, diante de tamanha 
sensibilidade, se mostraria mais econômica do que a implementação de um centro de imagem para diagnóstico da doença. No entanto, nenhum trabalho na literatura faz menção ao uso de PCR para se diagnosticar a NCC, o que indicou a possibilidade de desenvolvermos uma nova abordagem para se detectar tal infecção que viesse a se somar com as outras técnicas já disponíveis, buscando um diagnóstico mais rápido, barato e eficiente.

Figura 5 - Ciclo resumido de uma PCR. Ao final de 35 ciclos foram geradas, exponencialmente, cerca de 68 bilhões de cópias de um fragmento específico presente no DNA de um determinado organismo.

Fonte: http://allserv.rug.ac.be/ avierstr/pdf/PCR.pdf

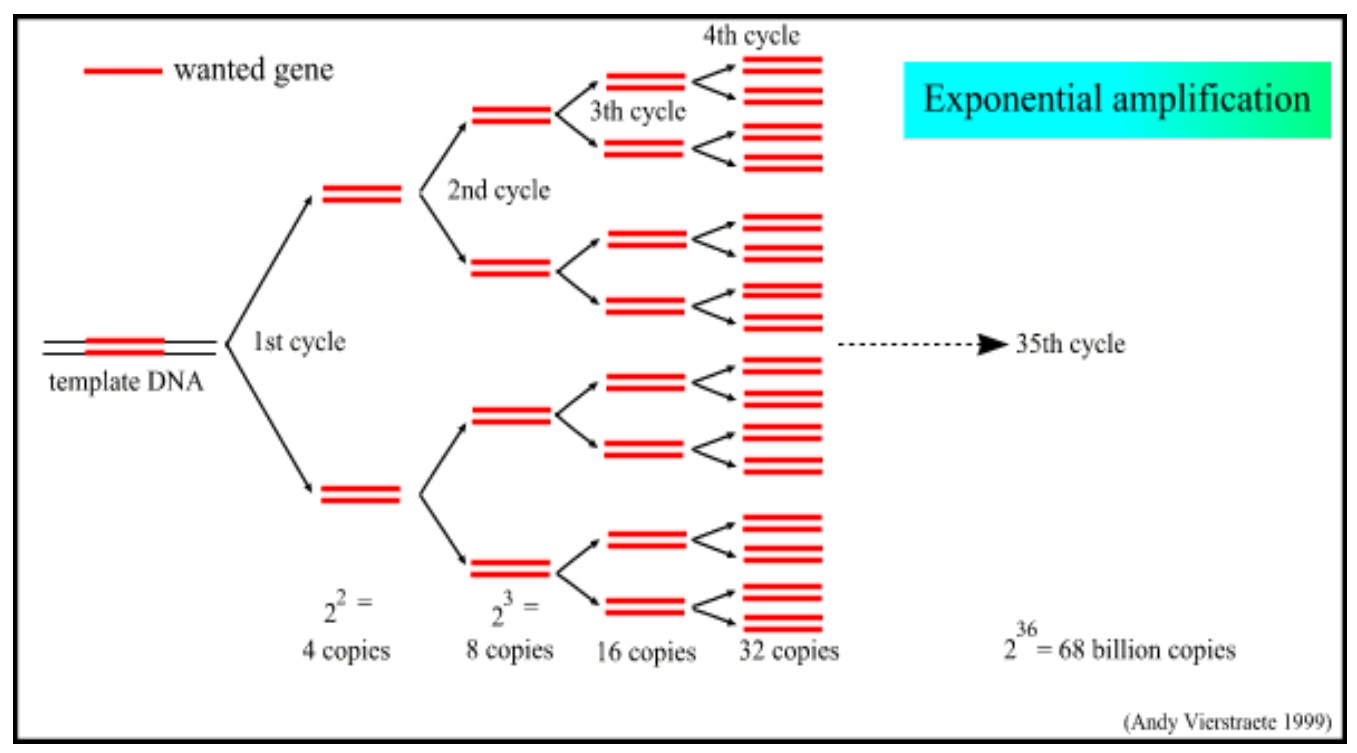

\subsubsection{O uso da PCR no estudo da Taenia e da teníase}

Os estudos que utilizaram técnicas de genética molecular em $T$. solium são poucos. Gonzaléz et al. (2002) utilizaram PCR como ferramenta para diferenciar proglotes e cistos de Taenia spp de diferentes regiões geográficas, coletadas de 22 pacientes nativos da Espanha, Colômbia e México. Este mesmo grupo desenvolveu, poucos anos antes, um diagnóstico diferencial de $T$. solium e $T$. saginata através de PCR utilizando sondas de DNA alcançando uma sensibilidade de detecção de 10pg (Gonzaléz et al., 2000). Yamasaki et al. (2004) 
desenvolveram um estudo baseado em copro-PCR (metodologia para identificação de $T$. solium e $T$. saginata em amostras fecais de pacientes) utilizando como gene alvo o citocromo c oxidase subunidade 1. Além disso, Nunes et al. (2003) utilizaram PCR para diagnosticar teníase em amostras fecais humanas, demonstrando que esta metodologia, com algumas modificações sugeridas a partir do trabalho de González et al. (2000), é capaz de amplificar dois fragmentos distintos; um de 600 pares de bases (pb) específico para identificação de portadores de $T$. saginata e um de 170 pb, que acusa a presença tanto de $T$. solium quanto de $T$. saginata. Assumindo que a quantidade de DNA presente em cada ovo destes parasitas é de 8 pg, o limite de detecção em amostras fecais encontrado por este grupo foi de 4375 ovos ou $35 \mathrm{ng}$ para evidenciar a presença de $T$. saginata, enquanto que a quantidade necessária para identificar apenas Taenia ssp. é de 137 ovos ou 1,096 ng. No entanto, todos estes trabalhos se concentraram na diferenciação entre as duas espécies fazendo um diagnóstico diferencial a partir de amostras fecais com o uso de genes mitocondriais, elementos de pequena repetitividade nas células do parasita.

A deficiência de estudos nesta área deve-se, em parte, à escassez de seqüências de DNA derivadas destes organismos, disponíveis nos bancos de dados públicos. Atualmente (11 de Março de 2005); no GenBank (www.ncbi.nlm.nih.gov), existem apenas 245 seqüências derivadas deste importante parasita. A grande maioria destas foi gerada durante a realização de estudos evolutivos e de filogenia do organismo, não tendo aplicação diagnóstica/imunológica imediata. No dbEST (www.ncbi.nlm.nih.gov/dbEST), uma divisão do GenBank que abriga seqüências parciais de cDNAs (DNA complementar), as ESTs (Expressed Sequence Tags), não existe nenhuma seqüência derivada de nenhuma espécie de Taenia.

\subsection{Estratégias de diagnóstico}

Dados atuais sugerem que a melhor maneira para se diagnosticar a NCC seja a somatória das interpretações obtidas das imagens cerebrais em conjunto com as avaliações neurológicas e imunológicas, além de dados clínicoepidemiológicos dos pacientes. Prova disso é que a sensibilidade da TC isolada é 
inferior ao método EITB; além disso, este último detecta anticorpos que podem indicar a forma ativa dos cistos e permite a localização de cisticercos tanto fora do SNC quanto em outras regiões.

Apesar de sua eficiência, o emprego conjunto de tais metodologias apresenta um custo muito alto, e por este mesmo motivo, não permite um fácil acesso por parte da população carente, a mais atingida por este tipo de parasitose.

Por esta série de motivos, faz-se necessário o desenvolvimento de novas alternativas diagnósticas que permitam a obtenção de resultados mais precisos, rápidos e de menor custo, além de poderem ser usadas como informações adicionais para reforças hipóteses diagnósticas baseadas em outros métodos. Deste modo, buscamos desenvolver neste trabalho, o primeiro diagnóstico molecular da neurocisticercose humana.

\subsection{Estratégias de prevenção}

Para reduzir o número de indivíduos infectados é necessário aplicar medidas capazes de interromper o ciclo biológico do parasita e conseqüentemente, a sua transmissão ao homem. Neste aspecto, seria extremamente desejável o desenvolvimento de estratégias de imunoterapia preventiva, capazes de prevenir o desenvolvimento e a implantação dos vermes adultos e das larvas em hospedeiros, humanos ou não.

\subsubsection{Desenvolvimento de vacinas contra a neurocisticercose}

Devido às diversas dificuldades encontradas no diagnóstico da NCC, algumas alternativas vêm sendo consideradas no combate à doença. Uma das opções mais importantes é o desenvolvimento de uma vacina capaz de prevenir a infecção nos hospedeiros.

Testes vacinais realizados na Austrália (Plancarte et al., 1999) demonstraram resultados promissores. O uso combinado de três diferentes antígenos atingiu uma proteção de 93\% (nível de redução de cisticercos viáveis em porcos experimentalmente infectados). 
Um outro estudo desenvolvido em uma comunidade rural mexicana mostrou que uma nova vacina sintética chamada SPvac, também baseada em três peptídeos sintéticos (18, 12 e 8 aminoácidos) compartilhados por $T$. solium e T. crassiceps reduziu em $52,6 \%$ a prevalência de cisticercose em porcos adquirida naturalmente, e mesmo aqueles que foram infectados tiveram a viabilidade de seus cistos diminuída em 98,7\% (Huerta et al., 2001). Uma desvantagem desta metodologia, no entanto, é o alto custo da síntese dos peptídeos sintéticos (Sciutto et al., 2002), o que torna este método preventivo economicamente inviável se levarmos em consideração a situação econômica das regiões mais infectadas.

Uma outra forma de se produzir vacinas é a clonagem de genes que codifiquem para antígenos imuno-protetores. Uma das abordagens usadas foi a clonagem do gene de $T$. solium similar ao antígeno 45W da Taenia ovis (genes TSO45), gerando proteínas recombinantes. Como esse antígeno recombinante (45W) foi capaz de conferir certa proteção ao hospedeiro, as proteínas geradas teriam o potencial de serem usadas na produção de uma vacina (Lightowlers \& Gauci, 2001).

Experimentos com extratos antigênicos de $T$. crassiceps vêm sendo desenvolvidos e tem demonstrado resultados promissores. Nos estudos mais recentes, antígenos de $T$. crassiceps foram capazes de proteger porcos experimentalmente infectados com ovos de $T$. solium (Sciutto et al., 1995). Este outro cestódeo vêm sendo muito usado, auxiliando no desenvolvimento de uma vacina para impedir o desenvolvimento da cisticercose em suínos devido algumas facilidades, tais como, a similaridade com o ciclo de vida de $T$. solium, a possibilidade de obtenção em modelos animais (BALB/c fêmeas adultas [8-12 semanas]) e por possuir uma rápida proliferação (brotamento).

Recentemente, Guo et al. (2004), concluíram que o antígeno cC1, derivado de $T$. crassiceps é um forte candidato ao desenvolvimento de uma vacina comercialmente viável contra a cisticercose causada pela $T$. solium, podendo também ser usado combinado com outros antígenos, pois é capaz de induzir uma resposta imunológica a qual está diretamente associada à duração da proteção dos hospedeiros (porcos). 
Apesar dos avanços até agora obtidos, com resultados indicando a viabilidade do desenvolvimento de uma vacina, é preciso concentrar esforços em se conhecer outros genes e proteínas do parasita, a fim de expandir o potencial de antígenos a serem testados. Além de sua possível utilização como antígenos vacinais, estes também teriam imediata aplicação na melhoria dos testes imunológicos atualmente disponíveis. Uma conseqüência importante deste incremento seria um estudo mais avançado sobre a variabilidade genética dos parasitas ao redor do mundo, com conseqüências óbvias sobre a efetividade de vacinas e antígenos em parasitas das mais diversas origens geográficas. Este tópico deve ser relevante, pois estudos sugerem que a $T$. solium tenha sido introduzida na América Latina e na África durante o período colonial e que provavelmente as espécies presentes em diversas regiões européias são diferentes das espécies encontradas na Ásia (Nakao et al., 2002), o que indica, por exemplo, que um isolado australiano pode diferir do brasileiro. Além disso, análises sorológicas revelaram que o fluido presente nos cistos de $T$. solium obtidos na China e na Indonésia e em Moçambique e no Equador indicaram diferenças marcantes nos padrões de bandeamento protéico obtidos (Ito et al., 2003). Portanto, ainda não se pode adotar no Brasil as mesmas estratégias tomadas na Austrália (por ter desenvolvido uma vacina aparentemente eficiente na proteção dos hospedeiros), pois há a necessidade de se conhecer genomicamente os isolados desse país, antes de se tomar medidas preventivas semelhantes.

As tentativas descritas acima têm o objetivo comum de produzir dados capazes de auxiliar no desenvolvimento de uma vacina. Uma possível proteção contra a manifestação da cisticercose em porcos (uma das fontes de transmissão da doença para os humanos) controlaria a transmissão da doença. Os antígenos recombinantes considerados aumentam as possibilidades de desenvolvimento de vacinas para assistir no controle da transmissão dessa parasitose. Uma diminuição ou a remoção da infecção nos porcos possivelmente controlaria a fonte de infecção nos humanos (Plancarte et al., 1999). Por esse motivo, essas novas tecnologias merecem total atenção e incentivos. 
Levando-se em consideração as dificuldades em se tratar e/ou prevenir a doença, os problemas em se conciliar todos os métodos diagnósticos para que a detecção do parasita seja precisa e eficiente, e a escassez de dados disponíveis sobre as informações genéticas de $T$. solium, torna-se necessário o desenvolvimento de estudos que possam caracterizar os genes desse parasita e associá-los a uma forma diagnóstica que venha a se somar com as já disponíveis, tornando-a cada vez mais eficiente. 


\section{OBJETIVOS}

\section{Objetivos Gerais:}

Avaliar o uso de amplificação de DNA no diagnóstico da neurocisticercose;

- Buscar maior conhecimento genômico do parasita pela geração de etiquetas de seqüências expressas (ESTs) durante o seu estágio larval.

\section{Objetivos Específicos:}

Buscar regiões repetitivas no DNA genômico de $T$. solium visando utilizá-las como alvo para testes diagnósticos;

$\checkmark$ Avaliar a sensibilidade e a especificidade de um método diagnóstico, baseado em amplificação de elementos repetitivos, em amostras biológicas humanas;

$\checkmark$ Gerar mil etiquetas de seqüências expressas em neurocisticercos, de modo a contribuir com o conhecimento genômico do parasita. 
Em vista dos objetivos propostos neste trabalho, esta tese foi dividida em dois blocos principais:

Bloco I: Diagnóstico - onde apresentamos e discutimos toda a metodologia empregada, bem como os resultados obtidos na busca pelo desenvolvimento de uma nova ferramenta diagnóstica para o diagnóstico da NCC.

Bloco II: Explorando o transcriptoma do cisticerco de Taenia solium - onde apresentamos e discutimos toda a metodologia empregada, bem como os resultados obtidos nas primeiras análises feitas no transcriptoma de $T$. solium. 
BLOCO I:

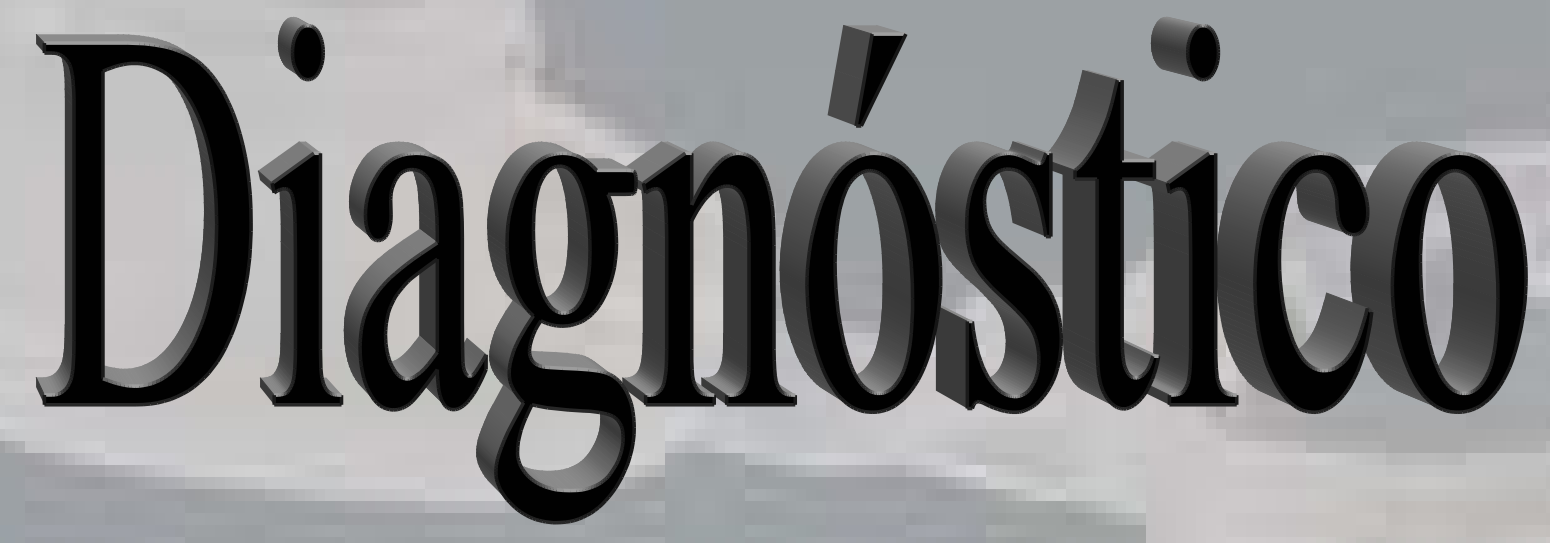




\section{MATERIAL E MÉTODOS}

\section{Material Biológico Utilizado}

\section{Parasitas}

Amostras de DNA de diversos parasitas (helmintos relacionados) foram utilizadas para padronizar e posteriormente verificar a especificidade do teste diagnóstico. Além do DNA de T. solium, utilizamos DNA de Schistosoma mansoni, $T$. crassiceps e $T$. saginata. Os cisticercos de $T$. solium foram obtidos de suínos infectados na região de Dourado (MS), enquanto que os cisticercos de $T$. crassiceps foram obtidos da cavidade abdominal de ratos experimentalmente infectados no laboratório da Profa. Dra Adelaide Vaz, da Faculdade de Ciências Farmacêuticas da USP, São Paulo, SP.

\section{Material Clínico}

Amostras de soro e de LCR de pacientes sabidamente saudáveis e/ou infectados foram também utilizadas. Tais amostras foram cedidas pela Profa. Dra. Adelaide José Vaz, da Faculdade de Ciências Farmacêuticas da USP; pelo Dr. Luis dos Ramos Machado, do Centro de Investigações Neurológicas da Faculdade de Medicina da USP e pelo Dr. Osvaldo Takayanagui, do Departamento de Neurologia da Faculdade de Medicina de Ribeirão Preto, Universidade de São Paulo. Foram utilizadas amostras de 10 pacientes sabidamente negativos e 30 pacientes sabidamente positivos para neurocisticercose. Este projeto de pesquisa foi aprovado pela Comissão de Ética para Análise de Projetos de Pesquisa, da Diretoria Clínica do Hospital das Clínicas da Faculdade de Medicina da USP, sob o protocolo de número 303/04.

\section{1 - Extração de DNA}

Para as extrações de DNA, os parasitas foram incubados com $500 \mu \mathrm{l}$ TES

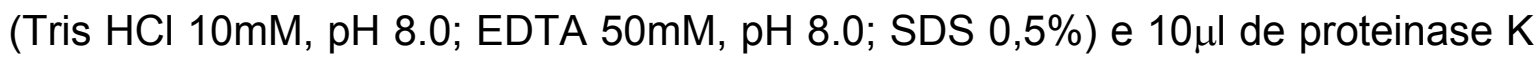
$(20 \mathrm{mg} / \mathrm{ml})$, em uma temperatura de $37^{\circ} \mathrm{C}$ durante três horas, um volume igual de fenol foi adicionado ao tubo. Este foi agitado por 30 seg e centrifugado a 11.000 
Xg por $10 \mathrm{mim}$. O sobrenadante foi transferido para um microtubo novo e o mesmo volume de fenol:clorofórmio:álcool isoamílico (25:24:1) foi adicionado. O tubo foi agitado por inversão durante $30 \mathrm{seg}$ e centrifugado a $11.000 \mathrm{Xg}$ por $10 \mathrm{~min}$ em temperatura ambiente. $\mathrm{O}$ sobrenadante foi transferido para um microtubo novo e o mesmo volume de clorofórmio foi adicionado ao tubo, o qual foi invertido algumas vezes, a fim de que a mistura fosse completamente homogeneizada, sendo, logo em seguida, submetido à centrifugação sob as mesmas condições. Ao sobrenadante foram adicionados $1 / 10$ do volume de acetato de sódio $3 \mathrm{M}$ e o dobro do volume final de etanol absoluto ou isopropanol. O produto final da extração foi incubado a $-80^{\circ} \mathrm{C}$ por $30 \mathrm{mim}$ e posteriormente centrifugado a 11.000 Xg por 15 min a $4^{\circ} \mathrm{C}$.

Após este procedimento, o sobrenadante foi descartado e o pellet foi secado a $37^{\circ} \mathrm{C}$ por $15 \mathrm{~min}$, sendo então ressuspendido em $50 \mu \mathrm{l}$ de TE $(10 \mathrm{mM}$ Tris, pH 8.0; $1 \mathrm{mM}$ EDTA, pH 8.0). O DNA extraído foi quantificado e avaliado em espectrofotômetro U-3010 Hitachi (Tokyo, Japan), com leituras feitas em 260nm e $280 \mathrm{~nm}$. Posteriormente, todas as amostras de DNA foram estocadas a $-20^{\circ} \mathrm{C}$.

\subsection{Busca de elementos repetitivos no genoma de Taenia} solium

Para iniciarmos os testes diagnósticos baseados em detecção de DNA, buscamos por elementos de DNA repetitivo nos bancos de dados públicos. Dentre as poucas seqüências disponíveis no início deste projeto, apenas uma estava descrita como sendo derivada de um elemento repetitivo. Tal seqüência havia sido descrita por Chapman et al., 1995.

Fizemos ainda a busca de outros elementos repetitivos no DNA do parasita, utilizando digestão total com enzimas de restrição. Para isto, usamos 15 enzimas de restrição (Tabela 1) realizando as digestões conforme instruções do fabricante. Após 3 horas de digestão, amostras equivalentes a $1 \mu \mathrm{g}$ de DNA digerido foram aplicadas em géis $1 \%$ de agarose, corados com Brometo de Etídio. A presença de um rastro indicava a digestão do DNA, enquanto que o surgimento de bandas definidas sugeriria fortemente a presença de elementos repetitivos contendo em sua seqüência o sítio de digestão da enzima utilizada. Após 
encontrarmos tais elementos, estes seriam excisados do gel, clonados e seqüenciados, evidenciando eventuais seqüências repetitivas.

Tabela 1 - Enzimas de restrição utilizadas na busca de elementos repetitivos no genoma de $T$. solium

\begin{tabular}{|c|c|c|}
\hline Enzima & $\mathrm{T}\left({ }^{\circ} \mathrm{C}\right)$ & Sítio de clivagem \\
\hline Alu I & 37 & AGICT \\
\hline Hae III & 37 & GGICC \\
\hline Hha I & 37 & GCGIC \\
\hline Hра II & 37 & C\CGG \\
\hline HpyCH4IV & 37 & A\CGT \\
\hline Mbo I & 37 & IGATC \\
\hline Mse I & 37 & TITAA \\
\hline Msp I & 37 & ClCGG \\
\hline Nla III & 37 & CATG \\
\hline Pal I & 37 & GGICC \\
\hline Rsa I & 37 & GT\AC \\
\hline Taq I & 37 & TICGA \\
\hline Fok I & 37 & GGATG \\
\hline $\mathrm{Bcl} /$ & 50 & T】GATCA \\
\hline Xho I & 37 & ClTCGAG \\
\hline
\end{tabular}

\section{3 - Amplificação do material genético do parasita}

Para amplificar o material genético de $T$. solium, utilizamos a técnica de PCR. Para tanto, oligonucleotídeos complementares à seqüência descrita por Chapman et al., 1995, foram desenhados, sintetizados (Invitrogene, São Paulo, Brasil) e usados para amplificar a unidade de repetição da nossa seqüência de estudo. 
A seqüência dos oligos utilizados foi:

5'- CAGGGTGTGACGTCATGG - TSRF1 3'(Forward - 18mer)

5'- GGAGGCCAGTTGCCTAGC - TSRR1 3'(Backward - 18mer)

Para a padronização inicial da amplificação, utilizamos 20ng de DNA de $T$. solium como molde. A reação foi conduzida em um termociclador MJ Research PTC-100 Thermal cycler (Watertown, MA) em um volume final de $10 \mu \mathrm{l}$ contendo $30 \mathrm{mM}$ Tris- $\mathrm{HCl}$ (pH 8.8); $15 \mathrm{mM} \mathrm{KCl} ; 3 \mathrm{mM} \mathrm{MgCl}_{2} ; 2$ pmol de cada oligonucleotídeo iniciador; 1,88 pmol de cada dNTP (Invitrogene, Califórnia, USA) e 1U de Taq DNA polymerase (New England, Biolabs; Beverly, MA). A amostra foi desnaturada inicialmente a $95^{\circ}$ durante $3 \mathrm{~min}$, seguida de desnaturação a $95^{\circ} \mathrm{C}$ por $45 \mathrm{seg}$, anelamento dos iniciadores a $56^{\circ} \mathrm{C}$ durante $1 \mathrm{~min}$. Optamos por utilizar um protocolo de Two Step PCR (sem extensão) para favorecer a amplificação de apenas uma unidade de repetição, tornando a reação mais sensível. A ciclagem total utilizada nesta reação foi de 38 ciclos.

Os produtos de PCR foram avaliados através de eletroforese em gel de poliacrilamida a $6 \%$ e corados com sais de prata (Sanguinetti et al., 1994).

\section{4 - Ensaios de especificidade}

Avaliamos a especificidade da PCR como método diagnóstico verificando os resultados obtidos quando DNA de outros parasitas relacionados, além de DNA humano, eram usados como molde de amplificação. Para tal, utilizamos DNA de $T$. saginata, $T$. crassiceps, S. mansoni e DNA humano com o mesmo par de iniciadores específicos para $T$. solium.

\section{5 - Ensaios de sensibilidade}

Para avaliar a sensibilidade do teste, utilizamos diluições seriadas sucessivas, partindo de $20 \mathrm{ng}$ até $0,01 \mathrm{fg}$ de DNA. A reação de amplificação e a avaliação dos resultados foram feitas conforme descrito para o bloco anterior. 


\section{6 - Ensaios de detecção de DNA de Taenia em amostras clínicas humanas}

Após avaliarmos a especificidade e a sensibilidade da PCR na detecção do DNA do parasita, iniciamos as análises utilizando amostras clínicas humanas de pacientes pré-diagnosticados.

\subsection{1 - Líquido Cefalorraquiano (LCR)}

Um total de 40 diferentes amostras de LCR, colhidas para diagnóstico imunológico de pacientes com suspeita de NCC, foram usadas em nossos ensaios.

Trinta destas amostras eram derivadas de pacientes com diagnóstico por imagem compatível com NCC. As demais se mostraram derivadas de pacientes com patologias não relacionadas à $T$. solium. Inicialmente, avaliamos a eficiência do teste em amostras brutas, isto é, usadas diretamente no tubo de amplificação, sem qualquer purificação prévia. Neste caso, os volumes de LCR utilizados diretamente na reação foram de 1, 3 e $5 \mu \mathrm{l}$. Em seguida, com o intuito de aumentar o poder diagnóstico do teste, purificamos e concentramos estas amostras, extraindo o DNA a partir de um volume de $100 \mu$ l de LCR. Para isso, utilizamos o kit Perfect gDNA Blood, (Eppendorf Scientific, Westbuty, New York, USA), seguindo as instruções do fabricante.

\subsection{2 - Soro}

Nestes ensaios, utilizamos 30 diferentes amostras de soro retiradas de pacientes sabidamente positivos para NCC, as quais foram devidamente purificadas e concentradas através da extração de DNA a partir de um volume de $100 \mu \mathrm{l}$ de soro utilizando o kit Perfect gDNA Blood, (Eppendorf Scientific, Westbuty, New York, USA), seguindo as instruções do fabricante. 


\section{RESULTADOS}

\section{Padronização da reação}

Utilizando as condições descritas em Material e Métodos, fomos capazes de padronizar a reação, amplificando os fragmentos de DNA esperados (Figura 6). Após a revelação dos resultados, identificamos um perfil composto por três bandas distintas, cada uma representando unidades múltiplas do elemento repetitivo presente no DNA deste parasita. A banda menor e mais intensa, observada para a amplificação de $T$. solium, possui 120 nt e representa a amplificação de uma única unidade de repetição. Como essa seqüência se repete em tandem no genoma, de modo quase perfeito (por seqüenciamento de DNA observamos um polimorfismo de G/A no terceiro nucleotídeo, além da perda de uma guanina na posição ocupada pelo décimo nt) é possível identificarmos a presença de mais duas bandas, uma de 278 pb e outra de 436 pb, compatíveis com a amplificação de, respectivamente, duas e três unidades de repetição contínuas.

Figura 6 - Gel de poliacrilamida $6 \%$ corado com prata, mostrando a amplificação do DNA de $T$. solium utilizando iniciadores dirigidos ao elemento repetitivo. A primeira canaleta contém o padrão de peso molecular utilizado (100pb). A segunda canaleta apresenta o resultado da amplificação utilizando DNA derivado de $T$. solium, bem como as três unidades de repetição presentes neste fragmento. 


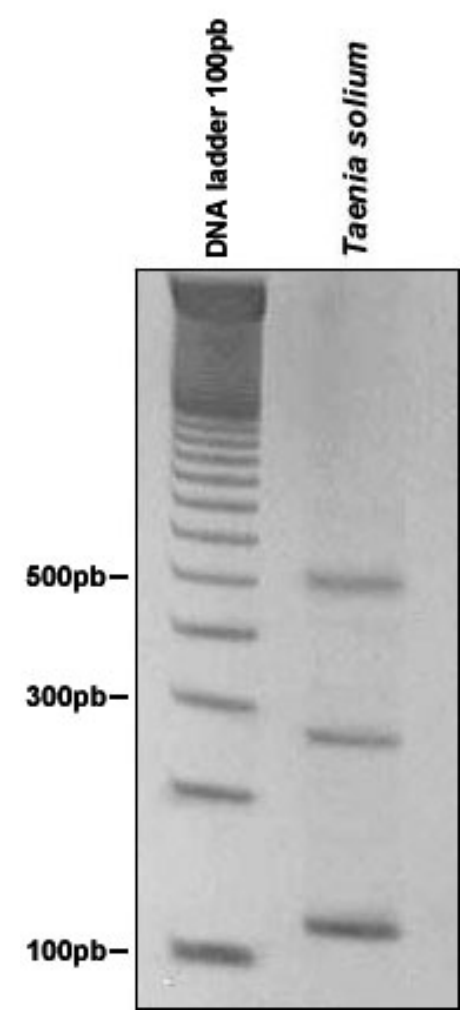

\section{Testes de especificidade}

A especificidade da amplificação foi avaliada utilizando-se como molde da PCR amostras de DNA derivadas de parasitas relacionados ( $T$. saginata, $T$. crassiceps, S. mansoni), além de amostras de DNA humano, assim como controles positivos ( $T$. solium) e negativos (sem DNA molde).

Os resultados, mostrados na Figura 7, confirmam a especificidade deste teste. O padrão característico da amplificação do elemento repetitivo foi observado apenas em amostras de $T$. solium. Além disto, demonstram amplificação de alguns fragmentos genômicos de $T$. crassiceps, com padrão de bandeamento distinto daquele observado para $T$. solium. 
Figura 7 - Avaliação da especificidade da PCR. Cada uma das canaletas mostra o perfil de amplificação obtido para as diferentes amostras. A primeira canaleta contém o padrão de peso molecular (100pb). As seguintes canaletas mostram o perfil obtido para DNA derivado de: T. solium, T. saginata, $T$. crassiceps, S. mansoni e Homo sapiens. Todas as amostras foram avaliadas em gel de poliacrilamida $6 \%$ corado com sais de prata.

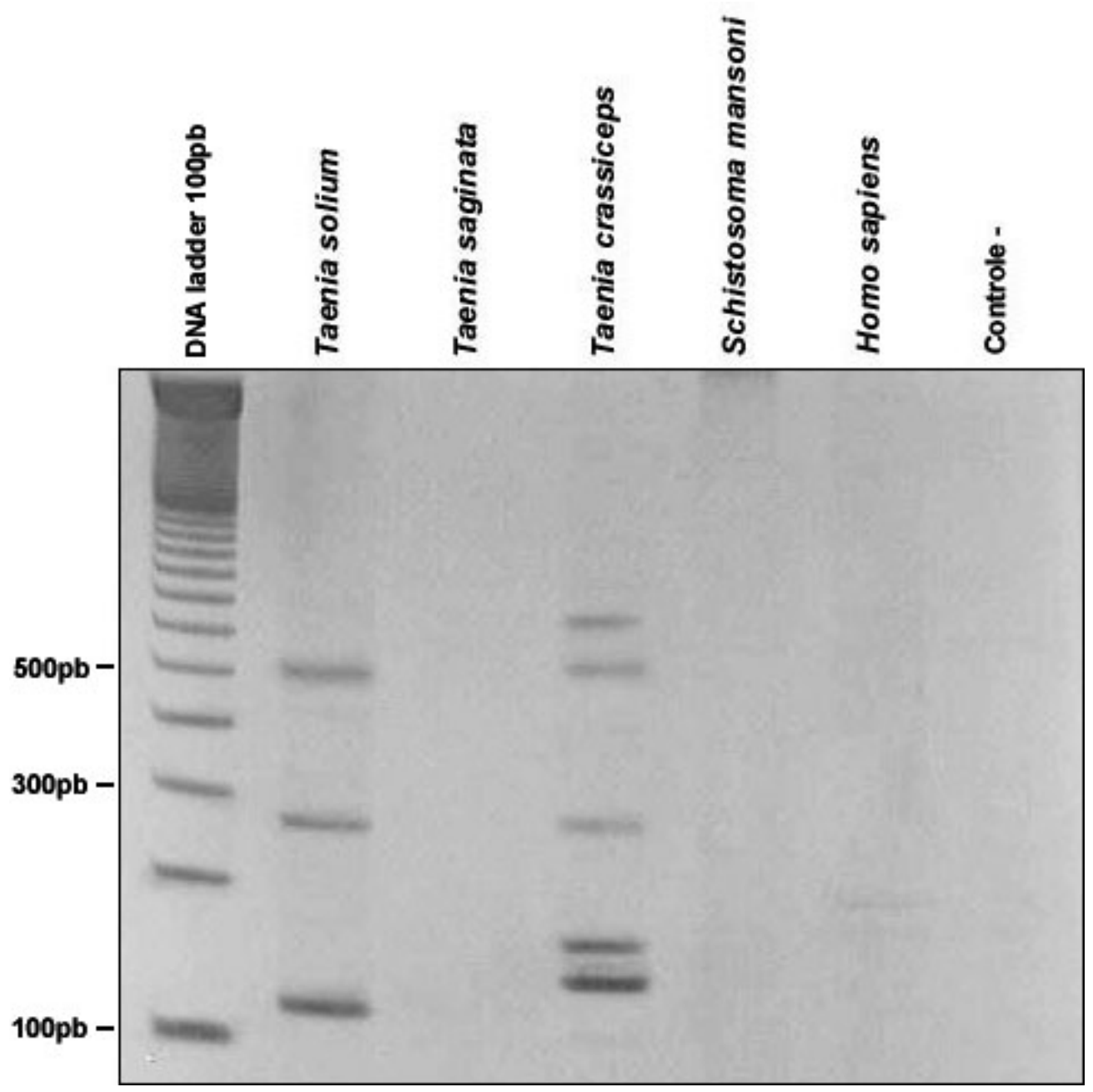

\section{Testes de sensibilidade in vitro}

Testes realizados com diluições seriadas propostas foram realizados e indicaram um limite de sensibilidade próximo a $10 \mathrm{fg}$ de DNA, conforme demonstrado na Figura 8. 
Figura 8 - Sensibilidade da PCR avaliada em diluições seriadas de DNA de T. solium. A primeira canaleta mostra o padrão de peso molecular (100pb). As outras canaletas (2-7) mostram as quantidades de DNA utilizadas na amplificação; respectivamente, 10pg, 1pg, 100fg, 10fg, $1 \mathrm{fg}$ e 0,1fg. Como pode ser visualizado logo abaixo, a PCR apresentou resultado positivo até $10 \mathrm{fg}$ de DNA de $T$. solium. Cinco microlitros de produtos de PCR foram avaliados em gel de poliacrilamida $6 \%$ corado com sais de prata.

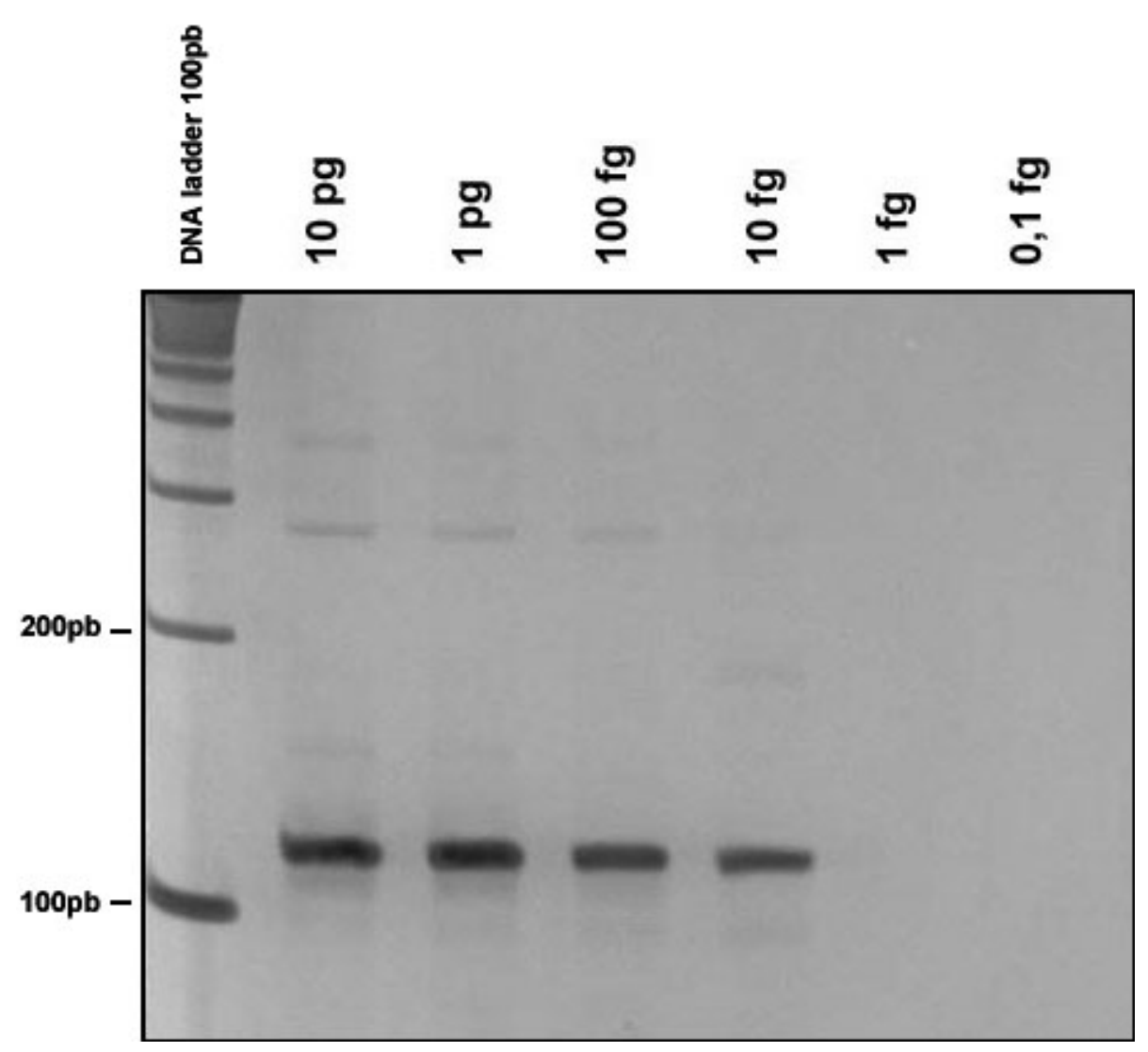

\section{Busca de DNA do parasita em amostras clínicas}

Inicialmente utilizamos um set de 20 amostras, tanto de LCR quanto de soro, de pacientes com diagnóstico de neurocisticercose confirmado por exames de neuroimagem. Todos os ensaios foram feitos utilizando três volumes diferentes de DNA molde, cada um destes em triplicata. Deste modo, para cada amostra de 
LCR, realizamos 9 amplificações de amostras brutas (sem extração) e mais 9 amplificações após a extração (como descrito a seguir). As amostras de soro foram avaliadas apenas após a extração do DNA.

\section{A - Amostras de LCR brutas}

Neste ensaio, utilizamos LCR diretamente nos tubos de reação.

As reações de amplificação foram devidamente preparadas sendo a elas adicionado, como molde, diferentes volumes de $\operatorname{LCR}(1,3$ e $5 \mu \mathrm{l})$ dos pacientes infectados. Este resultado está representado na Figura 9.

Figura 9 - Análise por PCR de 5 amostras de LCR de pacientes sabidamente positivos para neurocisticercose. O LCR dos pacientes foi diretamente adicionado ao mix de reação em diferentes volumes $(1,3$ e $5 \mu \mathrm{l})$. $\mathrm{O}$ padrão de peso molecular de 100 pb é mostrado na primeira canaleta e as duas últimas canaletas do segundo gel contém, respectivamente, os controles positivo (2ng de DNA de T. solium) e negativo (amostra sem LCR) da reação. As amostras foram avaliadas em géis de poliacrilamida a $6 \%$ corados com sais de prata.

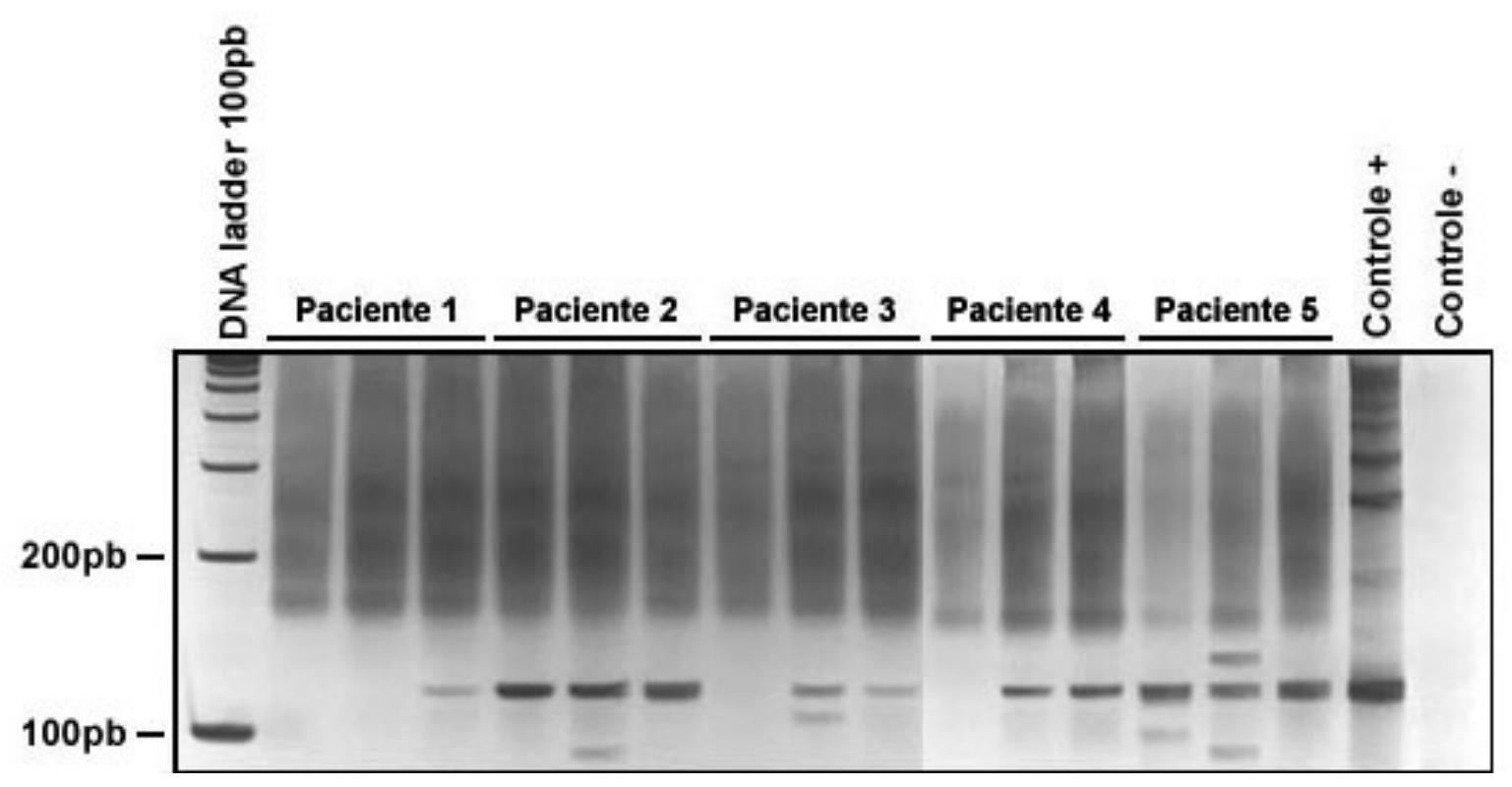




\section{B - Amostras de LCR purificadas}

As amostras de LCR também foram avaliadas após extração utilizando o kit Perfect gDNA Blood (Eppendorf Scientific, Westbuty, New York, USA). Um total de 30 amostras de pacientes positivos para NCC foi avaliado desta maneira. Como resultado final deste ensaio, fomos capazes de detectar o DNA do parasita em 29 dos 30 casos avaliados após a purificação de todas as amostras, o que aumentou sensivelmente a sensibilidade deste teste diagnóstico para $96,66 \%$.

A Figura 10 mostra resultados típicos obtidos de amostras brutas e após extração. Para permitir comparação dos resultados, apresentamos nesta figura resultados derivados das mesmas amostras de dois pacientes, antes e após a extração.

Figura 10 - Gel de poliacrilamida $6 \%$ corado com prata. Em A, observamos duas amostras de pacientes sabidamente positivos, cujo LCR foi utilizado diretamente na reação. Neste caso, observamos que o paciente 1 apresentou um perfil de amplificação muito sutil a partir de $3 \mu l$, enquanto que as amostras representadas pelo paciente 2 não amplificaram em nenhum dos volumes testados $(1 \mu, 3 \mu \mathrm{l}$ e $5 \mu \mathrm{l})$. Em B, vemos o perfil das mesmas amostras pós-purificação. Podemos observar que em ambos os casos há amplificação confirmando o diagnóstico pré-determinado.

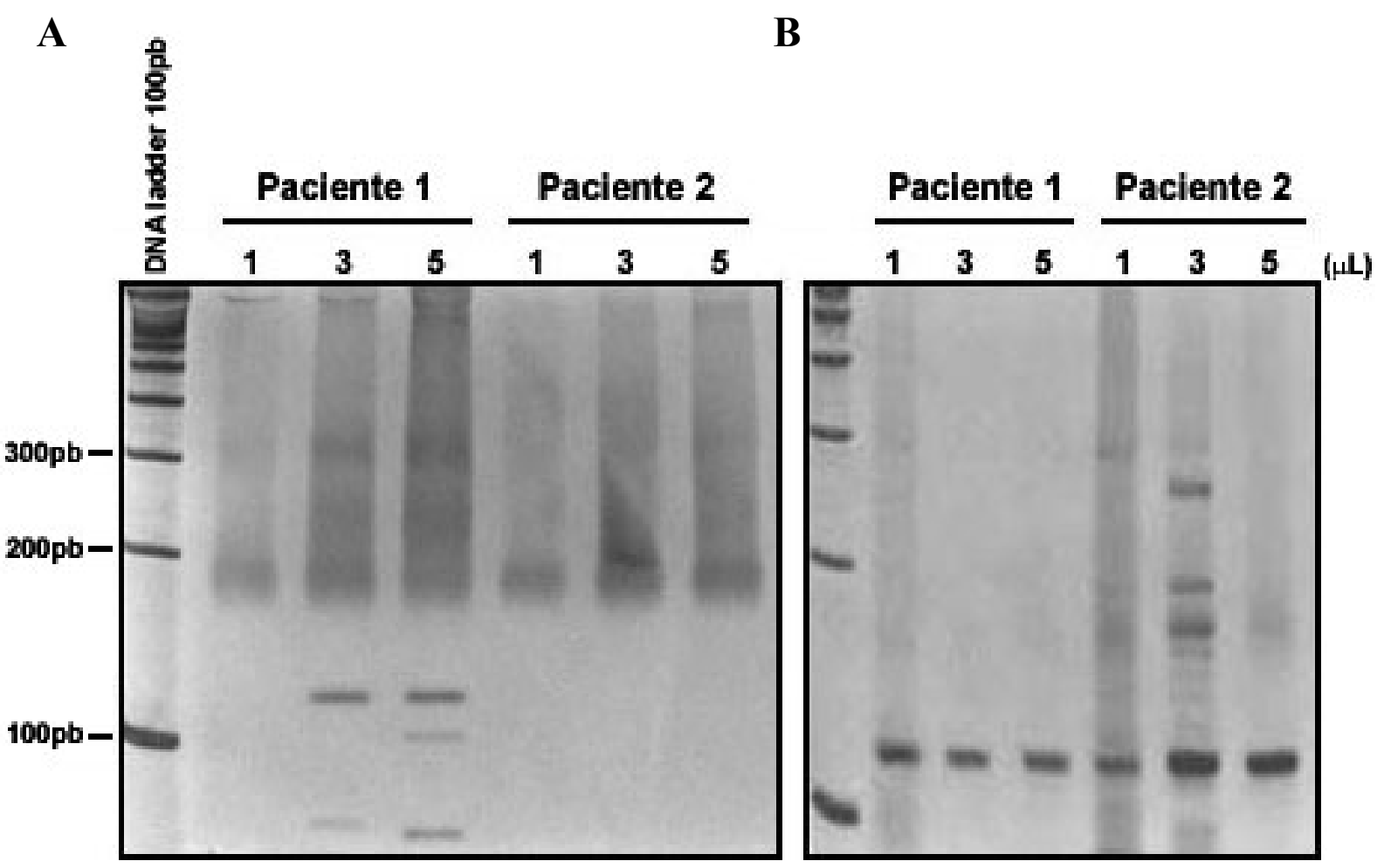


Os resultados finais obtidos para cada um dos pacientes são apresentados na tabela 2, a seguir:

Tabela 2 - Avaliação da PCR como método diagnóstico para neurocisticercose. Os sinais positivos são indicativos da presença de banda no gel, o que significa que houve amplificação; os sinais negativos indicam a ausência de amplificação nas amostras correspondentes.

\begin{tabular}{|c|c|c|c|}
\hline AMOSTRAS & $\begin{array}{l}\text { LOCALIZAÇÃO } \\
\text { DO CISTICERCO }\end{array}$ & $\begin{array}{l}\text { PCR COM LCR } \\
\text { "BRUTO" }\end{array}$ & $\begin{array}{l}\text { PCR COM LCR } \\
\text { PURIFICADO }\end{array}$ \\
\hline 1 & parênquima & + & + \\
\hline 2 & parênquima - LCR negativo para NCC & + & + \\
\hline 3 & parênquima & + & + \\
\hline 4 & parênquima & + & + \\
\hline $5^{*}$ & cisternal & - & + \\
\hline 6 & parênquima & + & + \\
\hline 7 & cisternal & + & + \\
\hline 8 & parênquima & + & + \\
\hline 9 & parênquima & + & + \\
\hline 10 & parênquima & + & + \\
\hline 11 & parênquima -LCR negativo para NCC & + & + \\
\hline $12^{*}$ & parênquima & - & + \\
\hline 13 & parênquima & + & + \\
\hline 14 & parênquima & + & + \\
\hline 15 & cisternal & + & + \\
\hline $16^{*}$ & parênquima & - & + \\
\hline 17 & ventrículo & + & + \\
\hline 18 & parênquima & + & + \\
\hline 19 & parênquima & + & + \\
\hline 20 & cisternal & + & + \\
\hline 21 & parênquima & - & + \\
\hline 22 & parênquima & - & + \\
\hline 23 & parênquima + meninges & - & + \\
\hline 24 & parênquima & - & + \\
\hline 25 & parênquima & - & - \\
\hline 26 & parênquima & + & + \\
\hline 27 & parênquima & - & + \\
\hline 28 & parênquima & - & + \\
\hline 29 & parênquima & + & + \\
\hline 30 & parênquima & + & + \\
\hline $31^{\#}$ & C.meníngea & - & - \\
\hline $32^{\#}$ & C. meníngea & - & - \\
\hline $33^{\#}$ & Intoxicação medicamentosa & - & - \\
\hline $34^{\#}$ & Tumor intramedular & - & - \\
\hline $35^{\#}$ & Cefaléia vascular & - & - \\
\hline
\end{tabular}


As linhas destacadas com um asterisco $\left({ }^{*}\right)$ indicam as amostras que apresentaram amplificação apenas após a extração/purificação das amostras de LCR; a linha destacada em negrito mostra o único caso em que uma amostra sabidamente positiva para NCC, diagnosticada por outras técnicas, não obteve um perfil de amplificação que confirmasse o seu diagnóstico; e as linhas destacadas com o símbolo $\left(^{\#}\right)$ indicam as amostras negativas utilizadas neste ensaio.

Desta forma, é possível observar que utilizando amostras brutas na reação a sensibilidade alcançada foi de $66.7 \%$ (20 das 30 amostras tiveram seu diagnóstico confirmado), porém, utilizando amostras purificadas a sensibilidade aumentou para 96.7\% (29 das 30 amostras apresentaram-se positivas para a presença de NCC).

\section{C - Amostras de soro purificadas}

Um total de 30 amostras de soro de pacientes positivos para NCC foram avaliadas após extração utilizando o kit Perfect gDNA Blood (Eppendorf Scientific, Westbuty, New York, USA). Como resultado final deste ensaio, embora tenha sido evidenciado sinal de amplificação, o perfil obtido não foi reprodutivo, impossibilitando a padronização da reação para estas amostras. A Figura 11 mostra um dos resultados obtidos na amplificação de amostras de soro após extração.

Figura 11 - Gel de poliacrilamida 6\% corado com sais de prata evidenciando o perfil de amplificação das amostras de soro de pacientes infectados com NCC. A primeira canaleta evidencia o padrão de peso molecular (100pb). As canaletas 2-5 mostram o perfil de amplificação obtido para duas amostras de soro de dois pacientes, cada um em dois volumes diferentes $(3 \mu \mathrm{l} e$ $5 \mu \mathrm{l})$. As canaletas 6 e 7 mostram os controles, respectivamente, negativo e positivo da reação. 


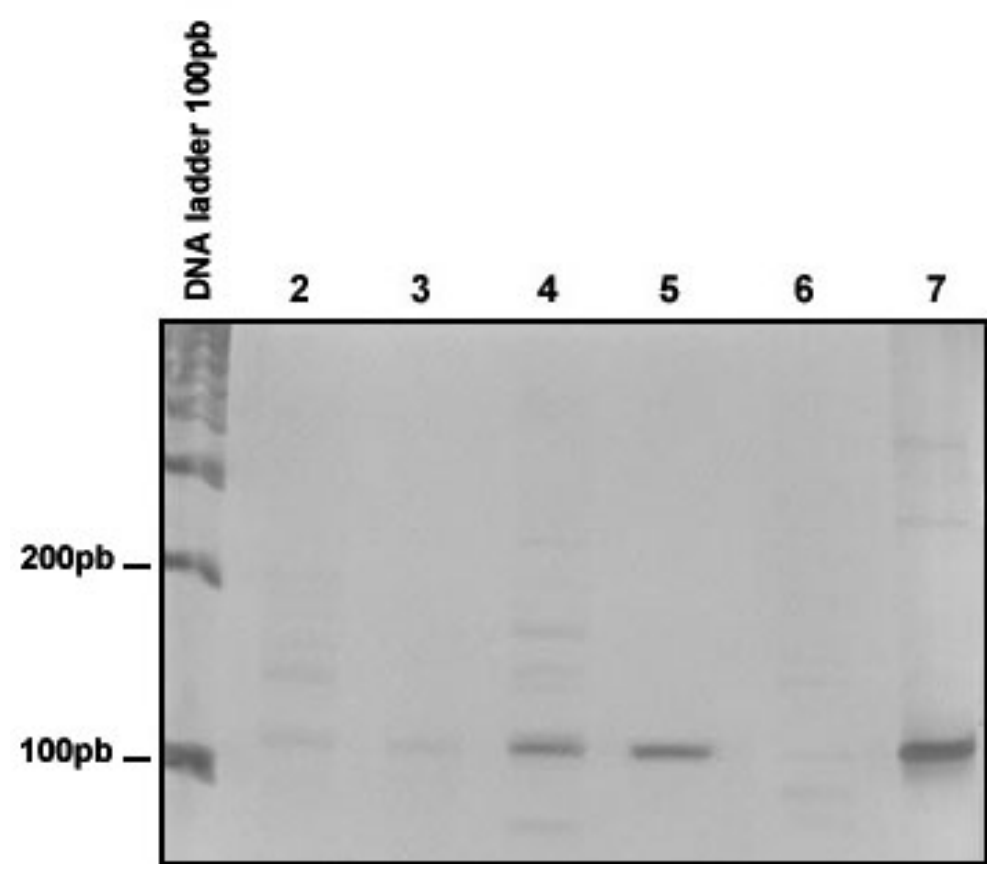

\section{Busca de novos elementos de DNA repetitivo por ensaios com} enzimas de restrição

Avaliamos também a possível existência de outros elementos repetitivos no genoma de $T$. solium que pudessem ter valor para diagnóstico molecular. Para isso, fizemos ensaios de digestão com 15 diferentes enzimas de restrição, selecionadas de acordo com a disponibilidade em nosso laboratório, tendo como único critério de seleção o número de nucleotídeos (4 a 6) do sítio de restrição, privilegiando os sítios mais curtos, que teriam maior probabilidade de digerir eventuais elementos repetitivos.

A figura 12 traz os resultados obtidos com algumas das enzimas utilizadas neste experimento.

Figura 12 - Gel de agarose 1\% corado com brometo de etídeo mostrando o perfil de digestão de $0,8 \mu \mathrm{g}$ de DNA genômico de $T$. solium obtido com algumas das enzimas de restrição utilizadas. A primeira canaleta mostra o padrão de peso molecular usado na reação (100pb); as canaletas 1-6 correspondem, respectivamente, as enzimas: Pal I, Rsa I, Msp I, Mbo I, Taq I e Alu I. 


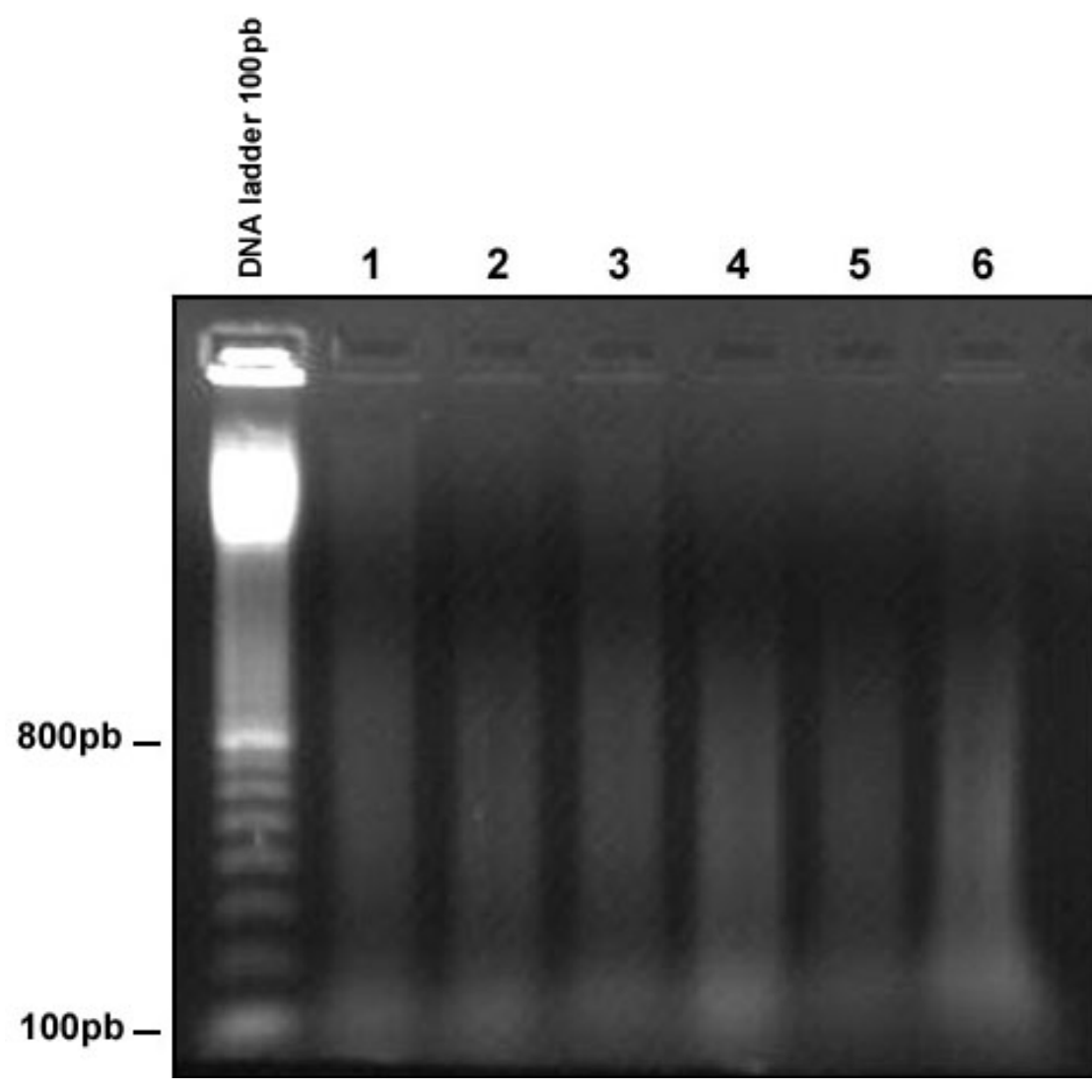

O arraste homogêneo indicando que houve digestão do DNA comprova a atividade das enzimas. No entanto, nenhuma das enzimas utilizadas foi capaz de sugerir a presença de novos elementos repetitivos, o que seria caracterizado pela presença de bandas definidas, evidenciadas em meio ao arraste de DNA genômico digerido. 


\section{DISCUSSÃO}

\section{Busca de elementos repetitivos no genoma de Taenia solium}

A busca de elementos repetitivos no genoma de $T$. solium foi iniciada com uma minuciosa busca nos bancos de dados públicos (Genbank). No entanto, análises neste banco demonstraram a ocorrência de apenas 390 seqüências nucleotídicas para o gênero Taenia, sendo que dessas, apenas 245 eram derivadas de $T$. solium (dados oriundos do banco de dados: Genbank http://www.ncbi.n/m.nih.gov/Taxonomy/Browser/wwwtax.cgi?mode=Info\&id=6204 $\&|v|=3 \& p=$ mapview $\& p=h a s$ linkout $\& p=b l a s t \quad u r l \& p=$ genome blast $\&$ lin $=f \& k e e p=1 \&$ srchmode=1\&unlock - de 11/03/2005). Cabe ainda notar que o banco de ESTs não contém nenhuma seqüência deste importante parasita. Deste modo, as fontes para buscas in silico de elementos repetitivos são extremamente reduzidas. No entanto, tivemos a sorte de encontrar no banco NR (non-redundant) do Genbank, a presença de uma única seqüência (U45987) de 538 nucleotídeos, incluindo 3 cópias completas de um elemento repetitivo de 158 pb (Figura 13). Tal seqüência foi descrita por Chapman et al. (1995) em trabalho onde o grupo preparou bibliotecas genômicas dos dois cestódeos ( $T$. solium e $T$. saginata). Metade dos clones obtidos hibridizavam igualmente com o DNA genômico de ambas espécies, os quais foram então eliminados. Os clones restantes da biblioteca de $T$. solium (30\%) hibridizavam predominantemente com o DNA deste parasita, os quais foram então separados. Posteriormente, através de análises de Southern blotting, muitos destes clones hibridizaram com a mesma banda de DNA de $T$. solium gerada após a digestão com a enzima Hae III, sugerindo que estes clones continham uma seqüência de DNA repetitiva em comum. Esta seqüência foi inicialmente isolada com o objetivo de diferenciar os ovos das duas espécies de helmintos mais importantes: $T$. solium e $T$. saginata, usando sondas de DNA que não haviam sido usadas para amplificação de DNA por PCR. Diante do caráter repetitivo deste elemento de DNA, conforme descrito no trabalho original, vislumbramos em nosso trabalho a sua utilização como base de um teste diagnóstico que detectasse a sua presença em amostras biológicas, permitindo investigar a presença de DNA do parasita em amostras clínicas dos pacientes. 
Os elementos repetitivos permitem o diagnóstico de frações sub-celulares oferecendo uma maior sensibilidade de detecção, principalmente quando pequenas quantidades de amostras estão disponíveis.

Figura 13 - Seqüência genômica repetitiva derivada do DNA de T. solium, descrita por Chapman et al., 1995. A figura evidencia as unidades de repetição usadas como alvo dos iniciadores usados em nosso trabalho, para a sua amplificação. As seqüências nucleotídicas destacadas em negrito indicam o início de cada uma das unidades de repetição presentes neste fragmento (sendo três unidades completas e uma parcial). As seqüências sublinhadas indicam os possíveis locais de anelamento dos iniciadores, que podem se ligar igualmente em qualquer uma das unidades de repetição. A principal banda de DNA esperada durante a amplificação é a de 120 pb.

Análises da seqüência U45987 contra todas as bases de dados públicas não demonstraram nenhuma similaridade significativa com qualquer seqüência descrita. Devemos notar que este banco, apesar de vasto, ainda é limitado, em geral se restringindo a organismos de maior interesse científico que já tenham sido analisados por seqüenciamento de DNA.

A pequena quantidade de seqüências conhecidas referentes a $T$. solium nos estimulou a contribuir para o conhecimento do conjunto de transcritos deste importante parasita (o que é apresentado no módulo 2 deste trabalho). O nosso trabalho de seqüenciamento permitiria avançar no conhecimento dos genes ativos 
do parasita e eventualmente poderia revelar algum outro elemento repetitivo útil para a realização de testes moleculares de diagnóstico.

No entanto, mesmo com as limitações inerentes a um pequeno número de seqüências inicial, as análises apontavam para um elemento repetitivo aparentemente específico para o genoma deste parasita. Deste modo, foi possível avançar na investigação da viabilidade de um teste diagnóstico molecular para a detecção do parasita.

Vale ressaltar que os elementos repetitivos constituem as ferramentas mais importantes para o diagnóstico molecular de importantes doenças. Em sua maioria, estes elementos são fragmentos genômicos não comprometidos diretamente com atividades funcionais de genes ou proteínas. Deste modo eles se encontram sob menor pressão seletiva, o que permite sua maior divergência nucleotídica. Isto os torna, em geral, espécie-específicos permitindo diagnóstico dirigido aos organismos de interesse. Tais elementos vêm sendo usados com sucesso no diagnóstico de algumas parasitoses causadas por organismos, tais como Trypanosoma cruzi, Leishmania, Plasmodium falciparum, Entamoeba histolytica, S. mansoni, Onchocerca volvulus, entre outros.

\section{Validação da PCR como método diagnóstico para neurocisticercose}

Uma das propostas deste trabalho foi o desenvolvimento de um método de diagnóstico molecular capaz de detectar fragmentos de DNA do parasita de modo sensível e específico em amostras clínicas derivadas de pacientes com NCC, visando fornecer um teste útil para complementar o diagnóstico da doença. Deste modo, a nossa pretensão foi oferecer uma ferramenta a mais, sem o intuito de substituir os testes atuais, pois acreditamos que só a integração de diversos métodos seria suficientemente capaz de diagnosticar de modo acurado a NCC diante de sua grande diversidade.

Em função da potencial agressividade do parasita $T$. solium e dos números alarmantes que acompanham tal infecção, associados à heterogeneidade clínica e à ausência de sintomas precoces e específicos (Fleury et al., 2004) que dificulta o diagnóstico preciso da doença, ainda há muito que fazer para melhorar os 
índices de infecção da doença, embora avanços importantes tenham surgido nas duas últimas décadas em relação à terapia e patologia desta infecção (Sciutto et al., 2000).

Com isso, as tentativas para se aperfeiçoar os métodos diagnósticos já existentes foram ampliadas ao mesmo tempo em que a busca por novas formas de identificar a infecção de uma maneira mais rápida e eficiente passou a ser um objetivo definido.

Embora a PCR venha sendo amplamente utilizada para diagnosticar doenças infecto-contagiosas (Pontes et al., 2002), nenhum estudo foi publicado no que se refere ao diagnóstico da NCC por este método.

Atualmente, a doença é mais bem compreendida do que há poucos anos (Garcia et al., 2003), porém, poucos avanços foram feitos na parte diagnóstica. $O$ método mais confiável continua sendo o baseado em imagem (Carpio, 2002), em alguns casos, extremamente inviável considerando as condições sócioeconômicas da maioria da população afetada por esta doença.

Em nossas primeiras análises vimos que o elemento repetitivo presente no genoma de $T$. solium descrito por Chapman et al. (1995) não havia sido avaliado como alvo para o diagnóstico da infecção, e que este poderia ser um alvo alternativo para auxiliar na identificação e controle da doença.

A amplificação deste elemento repetitivo resulta em um padrão simples e claro de amplificação. Embora cada um dos elementos de repetição seja composto por 158 nucleotídeos, as bandas esperadas no gel devem apresentar 120, $278(120+158)$ e $436(120+158+158)$ pares de base. Esses números representam a unidade de repetição de acordo com a posição de anelamento dos iniciadores no interior do fragmento. O primeiro fragmento amplificado contém 120 nucleotídeos, se considerarmos da primeira até a última base na qual os iniciadores se anelam; o segundo fragmento contém 278 , pois contém uma unidade de repetição completa além do fragmento de 120 nucleotídeos; a terceira banda observada apresenta 436 pares de bases, é idêntico ao segundo, apenas acrescido de mais uma unidade de repetição.

Nos géis podemos notar que as bandas de menor tamanho são mais facilmente amplificadas que as bandas de maior tamanho. Isso acontece porque a 
probabilidade de se amplificar o menor fragmento é sempre maior do que a de amplificar fragmentos maiores, pois sempre que ocorre a amplificação de um dos fragmentos longos, um ou mais dos sítios de ligação dos iniciadores não é utilizado. Além disto, empregamos em nossa reação um programa de amplificação dirigido para a amplificação de uma única unidade de repetição, buscando desfavorecer ainda mais as bandas maiores.

Diante dos resultados iniciais que indicavam a padronização da amplificação, avaliamos duas importantes variáveis, a saber: a sensibilidade e a especificidade do teste.

\section{Especificidade do teste diagnóstico}

Para avaliar a especificidade da PCR como método diagnóstico para NCC, vários testes foram feitos utilizando amostras de diferentes organismos. O objetivo era verificar se, com este par de iniciadores, haveria amplificação do DNA de outras espécies, com maior ênfase em organismos filogeneticamente relacionados à $T$. solium, ou em amostras de DNA com alta probabilidade de se encontrarem presentes em testes diagnósticos utilizando amostras clínicas (DNA humano e DNA de outros parasitas freqüentemente encontrados em indivíduos parasitados pela $T$. solium). A amplificação de fragmento de tamanho igual ou próximo ao observado para $T$. solium deveria indicar a inviabilidade do teste em seu presente formato.

Assim, tornou-se imprescindível assegurar que durante os experimentos apenas o material genético de $T$. solium permitisse gerar o perfil de amplificação esperado. Para que o teste fosse específico, seria necessário avaliar se outras infecções relacionadas não apresentariam um perfil de amplificação compatível com aquele obtido para o DNA de T. solium. Para verificar a especificidade da PCR fizemos ensaios utilizando outros DNAs como molde. Como apresentado na Figura 7, o perfil obtido com a amplificação do DNA deste parasita se mostrou diferente dos demais. A única espécie que foi amplificada além de $T$. solium foi a de $T$. crassiceps, e mesmo assim com um perfil totalmente distinto, sem características de bandeamento compatíveis com um elemento de repetição em tandem. Estas bandas obtidas do DNA de T. crassiceps podem indicar a presença 
de um elemento repetitivo homólogo, degenerado neste segundo parasita. Sendo a $T$. crassiceps um excelente modelo laboratorial para a $T$. solium, acreditamos que estas bandas possam ser exploradas no contexto de permitir acompanhar a evolução de tratamento e diagnóstico de infecção em modelos animais.

\section{Sensibilidade do teste diagnóstico}

Ao lado da especificidade, a sensibilidade é outro fator igualmente fundamental em um teste diagnóstico. Se o novo teste aqui proposto apresentasse alta especificidade somado a alta sensibilidade, poderíamos vislumbrar a possibilidade de oferecê-lo para ampliar o leque de opções diagnósticas disponíveis para esta doença.

Partimos então para a determinação da sensibilidade deste teste. A princípio, avaliamos a capacidade mínima de DNA do parasita capaz de gerar sinal de amplificação detectável. Como pode ser visto na Figura 8, a PCR permitiu detectar quantidades mínimas de material genético do parasita. Na figura, são apresentados os resultados derivados de PCR a partir de 10pg indo até $0,1 \mathrm{fg}$ de DNA. Neste ensaio determinamos a quantidade mínima de DNA capaz de gerar sinal de amplificação visível em nosso sistema de detecção. Tal ponto, consistentemente obtido em diferentes experimentos, foi determinado como sendo de $10 \mathrm{fg}$. Supondo que a quantidade de DNA de Taenia contido em uma única célula diplóide do parasita esteja ao redor de $314 \mathrm{fg}$, isto indica que nosso teste é capaz de apontar para uma quantidade de DNA correspondente a $3 \%$ do DNA contido em uma única célula. Estes resultados sugeriram um bom potencial da PCR como método diagnóstico, o que nos estimulou a investigar a presença de DNA em amostras clínicas de pacientes.

\section{Busca de DNA do parasita em amostras clínicas}

Com o apoio de colaboradores da Faculdade de Ciências Farmacêuticas da USP, do Depto de Neurologia do HCFMUSP e do Depto de Neurologia da Faculdade de Medicina de Ribeirão Preto (USP), amostras de LCR e soro de pacientes portadores de NCC foram utilizadas nos experimentos seguintes. 
A idéia de utilizarmos inicialmente o LCR como alvo para busca do DNA surgiu pelo fato deste fluido ser bastante límpido, com pequena quantidade de outros componentes que eventualmente poderiam inibir a atividade enzimática necessária para a amplificação do DNA em um teste diagnóstico baseado na PCR. Aliado a isto estava a disponibilidade de material previamente adquirido por nossos colaboradores, que rotineiramente coletavam LCR dos pacientes suspeitos a fim de realizar testes imunológicos já consagrados.

A obtenção de soro, por outro lado, é extremamente simples e rápida, além de não ser um procedimento invasivo e doloroso. Uma simples coleta de sangue seria suficiente para disponibilizar tais amostras. No entanto, por ser um fluido muito heterogêneo em sua composição (proteínas, sais inorgânicos, aminoácidos, vitaminas, hormônios, lipídios, leucócitos) (Junqueira \& Carneiro, 1985), sua purificação seria necessária considerando que tais componentes interferem e podem inibir a reação de amplificação (Bueno et al., 2000).

\section{Ensaios com Líquido Cefalorraquiano (LCR)}

\section{1 - Amostras de LCR brutas}

Os ensaios iniciais foram preparados utilizando as amostras de LCR diretamente na reação, processo esse que, caso apresentasse resultados satisfatórios, seria muito mais eficiente por representar uma sensível agilidade na validação dos diagnósticos, ao mesmo tempo em que reduziria os custos da reação.

O primeiro set de amostras estudadas continha 20 amostras de LCR de pacientes pré-diagnosticados para NCC e com diagnóstico positivo. Foram também utilizadas 10 amostras de pacientes comprovadamente negativos como controles de reação. Todos os ensaios foram realizados em triplicata e com três volumes diferentes $(1 \mu \mathrm{l}, 3 \mu$ e $5 \mu \mathrm{l})$. O número, a localização e principalmente o estágio de evolução dos cisticercos estão diretamente relacionados com a intensidade de amplificação do DNA. Em alguns casos, um único cisto muito ativo é capaz de gerar um perfil bastante claro de infecção, com bandas fortes e bem definidas; por outro lado, há casos em que o cérebro pode conter inúmeros cistos, 
alguns em processo de degeneração, outros em regiões menos propícias à detecção, de modo que o perfil de amplificação não é tão evidente quanto o esperado. Esta foi a razão pela qual os ensaios foram repetidos três vezes, buscando uma maior acurácia das informações.

Como resultado, 16 das 20 amostras foram amplificadas, atingindo uma sensibilidade de $80 \%$.

Estes dados estão apresentados na Figura 9, onde observamos que para algumas amostras, $1 \mu \mathrm{l}$ de material não foi suficiente para gerar sinal de amplificação (o que pode ser visto para os pacientes 1, 3 e 4); por outro lado, quando $5 \mu \mathrm{l}$ de amostra foram utilizados como molde é possível que tenha ocorrido uma inibição da reação por componentes presentes no LCR (resultado representado pelo paciente 3 , onde ao utilizarmos $3 \mu \mathrm{l}$ de LCR evidenciamos uma banda mais forte do que a apresentada quando $5 \mu$ foram usados). Os pacientes 2, 4 e 5 apresentaram um perfil onde a intensidade das bandas vai crescendo à medida que o volume de LCR utilizado na reação vai aumentando. Em última análise, o paciente 1 apresenta um perfil onde a banda só aparece com $5 \mu$, indicando que, em pequenas quantidades de LCR (como por exemplo $1 \mu$ ), pequena quantidade de material genético do parasita poderia estar disponível dificultando uma amplificação mais robusta. Em nossa rotina, empregamos 3 volumes diferentes de LCR na reação. Em se tratando de padronização de um novo método, adotamos este procedimento em nossa investigação. Acreditamos que este procedimento era necessário pelo fato do surgimento das bandas de amplificação estar limitado a fatores intrínsecos ao teste. Se por um lado o uso de grandes quantidades de LCR forneceria maior quantidade de DNA molde e maior probabilidade de amplificação, esta grande quantidade de material biológico poderia trazer consigo outros elementos que ocasionariam uma inibição da PCR. Do mesmo modo, se utilizamos quantidades menores de amostra, visando à redução dos elementos inibidores, esta redução também se daria no DNA molde necessário para a visualização dos produtos de amplificação. Ambos os extremos poderiam resultar em um aumento dos falso-negativos. Uma reação bem padronizada deve lidar com estas questões, buscando o equilíbrio entre uma 
quantidade tolerável de inibidores e o máximo possível, dentro deste limite, de DNA amplificável.

Posteriormente, tivemos acesso a um segundo set de amostras composto por 10 pacientes com diagnóstico positivo para NCC. Os ensaios foram conduzidos da mesma maneira discutida acima, indicando uma sensibilidade final para as 30 amostras de $66,7 \%$, quando utilizamos LCR diretamente aos tubos de PCR.

\section{2 - Amostras de LCR purificadas}

$\mathrm{Na}$ tentativa de aperfeiçoar o teste e aumentar a sua sensibilidade, utilizamos estas mesmas amostras em sua forma purificada. Esta alternativa foi utilizada a fim de eliminar eventuais impurezas que poderiam estar reduzindo a capacidade de amplificação, além de concentrar o DNA eventualmente presente nas amostras clínicas. Para isso, utilizamos o kit Perfect gDNA Blood (Eppendorf Scientific, Westbuty, New York, USA) seguindo as instruções do fabricante. O volume de $100 \mu$ l de LCR foi utilizado no protocolo de extração, sendo que o DNA foi posteriormente eluído e concentrado em $25 \mu$ l de água.

A Figura 10 exemplifica alguns dos resultados obtidos. Em $\mathbf{A}$, temos resultados derivados de dois pacientes cujo LCR foi utilizado diretamente como fonte de DNA molde. O paciente 1 apresentou uma discreta amplificação com $3 \mu \mathrm{l}$ ou $5 \mu l$ de LCR, já o paciente 2 não apresentou qualquer indício de amplificação em nenhum dos volumes testados nestas condições. Porém, após a purificação, como mostrado em B, a intensidade das bandas visualizadas anteriormente no paciente 1 foi aumentada, além de ter sido possível evidenciar sinais de amplificação mesmo quando $1 \mu$ do eluato de LCR era utilizado. Ainda mais evidente é o perfil apresentado pelo paciente 2; antes da extração, nenhum sinal de amplificação era visto, no entanto, após a purificação da amostra houve clara amplificação em todos os volumes de LCR utilizados.

Estes resultados comprovam a hipótese de que, por mais puro que seja o LCR, outros componentes e/ou impurezas (proteínas, peptídeos, neuropeptídeos, hormônios, açúcares, enzimas, etc.) presentes estariam, de alguma forma, interferindo na amplificação do material genético de $T$. solium, dificultando um 
diagnóstico correto. Assim, após a utilização de nosso protocolo de purificação, 29 das 30 amostras avaliadas apresentaram um perfil compatível com seu prédiagnóstico, elevando nossa sensibilidade para $96,7 \%$.

Análises de dados clínicos fornecidos por nossos colaboradores permitiram investigar mais cuidadosamente o único paciente que não fomos capazes de diagnosticar com nosso teste. Este paciente apresentava a forma epiléptica e meningítica da doença; com poucas lesões císticas com escólex (apenas três) e múltiplas calcificações, comprovadas por RM. Tais cistos foram identificados como sendo de forma racemosa.

Este caso de falso-negativo pode ter surgido por degradação do DNA molde durante a coleta, estoque, extração ou manipulação do LCR, ou talvez a quantidade de DNA disponível no LCR estivesse aquém do nosso limite de detecção. No entanto, não deixa de ser curioso o fato de este ter sido o único dos 30 casos onde o paciente apresentava a inusitada forma racemosa.

Por outro lado, devemos ressaltar que duas das amostras (amostra 2 e 11) apresentaram-se negativas quando avaliadas através dos testes imunológicos, porém, quando avaliadas por PCR mostraram-se positivas. A Tabela 2 mostra todos os resultados da PCR obtidos para cada uma das amostras de LCR nas condições em que foram testadas, além de mostrar o número de cistos presentes no cérebro dos pacientes correspondentes.

\section{3 - Amostras de soro purificadas}

O aparecimento de bandas na amplificação das amostras de soro foi inconsistente durante todo o período, apesar de diversas tentativas de otimização da amplificação. Tais resultados são característicos de amostras contendo quantidades mínimas de DNA molde, com uma ou menos moléculas amplificáveis na reação. A Figura 11 mostra o perfil de amplificação típico obtido com soro. Esta figura retrata nosso melhor resultado para amostras de soro, sendo que tais resultados não foram reprodutíveis, impossibilitando sua utilização para análises diagnósticas. Na tentativa de melhorar a padronização da reação para aperfeiçoar os perfis de amplificação, novas bandas inespecíficas surgiram em conseqüência do aumento da quantidade dos reagentes e do tempo de reação empregados, no 
entanto, não melhorando de maneira consistente a visualização e a intensidade da banda alvo. Estes resultados apontam para a existência de DNA do parasita, e sugerem que elementos repetitivos de maior freqüência no genoma do parasita poderiam eventualmente ser empregados como alvo em novas análises, permitindo que este material fosse utilizado com maior sucesso.

Diante das múltiplas características em que a NCC se apresenta, a instabilidade (os cistos podem migrar) e a variedade da localização e do número de cistos, há a necessidade de se aperfeiçoar cada vez mais a acurácia dos métodos diagnósticos para garantir confiabilidade nos resultados. Acreditamos que o melhor diagnóstico ainda é feito por uma somatória das técnicas hoje disponíveis, mas em vista das dificuldades e limitações impostas, temos que optar por aquelas que melhor se encaixam nas necessidades dos afetados.

A PCR apresentou-se como uma ferramenta eficaz no diagnóstico desta doença, superando em alguns casos as falhas e/ou a eficácia apresentada por outros métodos, além de ser um processo rápido e acessível, principalmente à população mais atingida. Apesar disso, também possui algumas ressalvas importantes. É um método que exige muitos cuidados e atenção, pois está sujeito a produção de resultados falso-positivos quando há uma possível contaminação por DNA exógeno; falso-negativos, quando do pequeno volume de amostra disponível ou da inadequada remoção de inibidores da reação; ou ainda da pobre recuperação de DNA após o procedimento de purificação (Yang \& Rothman, 2004).

O fato é que não podemos ignorar sua utilidade descartando sua eficiência quanto sua especificidade e sensibilidade, bem como seu baixo custo, agilidade e praticidade, mas enfatizamos que o melhor método diagnóstico ainda continua sendo a somatória de todos os que estão hoje disponíveis. Não estamos propondo um método substituto e sim, disponibilizando mais uma ferramenta, a primeira baseada em técnicas de biologia molecular, para o diagnóstico de neurocisticercose. 
Os dados referentes a este bloco foram organizados e submetidos à publicação em revista especializada (ANEXO 1) e partimos para a segunda etapa do trabalho.

\section{Busca de novos elementos repetitivos por enzimas de} restrição

Diante dos resultados obtidos, satisfatórios para PCR, mas ainda inadequados para detecção de DNA livre no soro, seria interessante ampliar os conhecimentos sobre o genoma da $T$. solium buscando outros elementos genéticos que pudessem representar alvos diagnósticos até mais sensíveis (elementos repetitivos com maior número de cópias).

Uma das metodologias empregadas para este propósito foi a digestão do DNA com diversas enzimas de restrição. Tais enzimas possuem sítios de clivagem específicos compostos por uma quantidade variável de nucleotídeos. Assim, selecionamos aquelas cujo sítio de restrição era composto por quatro a seis nucleotídeos, a fim de aumentar a probabilidade de encontrarmos um elemento repetitivo que contivesse um sítio de restrição em sua seqüência. $A$ existência deste sítio em um elemento com grande número de cópias deveria gerar bandas de mesmo tamanho, de modo altamente consistente. A intensidade da banda deveria ser proporcional à freqüência dos elementos repetitivos no genoma investigado. A fim de aumentarmos nossas chances de encontrar este elemento, buscamos digerir o DNA preferencialmente com enzimas que reconhecessem um sítio de digestão composto por apenas 4 bases. Considerando que a probabilidade de um nucleotídeo em específico estar ocupando uma determinada posição no genoma é $1 / 4$, e considerando uma distribuição de nucleotídeos ao acaso no genoma, teríamos que uma enzima com sítio de clivagem de quatro bases teria uma chance em cada 256 nucleotídeos $\left[(1 / 4)^{4}\right]$ de reconhecer e "cortar" o DNA em determinado ponto, facilitando o processo de localização de outros eventuais elementos repetitivos presentes no genoma de $T$. solium. 
Para os ensaios realizados adotamos como padrão o volume final de $20 \mu$, nos quais utilizávamos cerca de $1 \mu \mathrm{g}$ de DNA e $1 \mu \mathrm{l}$ de cada enzima. $\mathrm{O}$ tempo de incubação variou entre 1 e 2 horas.

Como mostra a Figura 12, com as enzimas que utilizamos observamos a digestão do DNA do parasita, mas sem sucesso na sugestão de elementos repetitivos. Este resultado não elimina a possibilidade de haverem outros elementos de repetição no genoma de $T$. solium, mas esta hipótese só poderia ser confirmada com o uso de outras enzimas, pela confecção de bibliotecas genômicas dirigidas a elementos repetitivos ou após o seqüenciamento completo do genoma do organismo. Na segunda parte deste trabalho, nos propusemos a gerar as primeiras 1000 ESTs deste organismo, não só visando auxiliar estudos futuros que pudessem contribuir com formas diagnósticas cada vez mais apropriadas, tanto do ponto de vista molecular (inédito até o desenvolvimento deste trabalho), quanto do ponto de vista imunológico (conhecendo novos antígenos e/ou alvos quimioterápicos), mas também oferecendo condições para o desenvolvimento de uma vacina. Além disso, todas as informações geradas serão depositadas nos bancos de dados públicos e devem fomentar a pesquisa nesta área. 


\section{CONCLUSÃO}

Neste módulo, podemos concluir que:

- Comprovamos a presença de um elemento repetitivo no genoma de $T$. solium, com potencial utilidade diagnóstica;

- Comprovamos a existência de DNA de $T$. solium em fluidos corporais (LCR e soro) de pacientes com NCC;

- A especificidade da PCR alcançada aqui foi de 100\%, sem que tenhamos observado reações cruzadas com outros parasitas relacionados;

- A sensibilidade observada em diluições seriadas de DNA alcançou o limite de $10 f g$ de DNA;

- Ao avaliar amostras de LCR confirmamos a infecção em 29 das 30 amostras pré-diagnosticadas, com uma sensibilidade em amostras clínicas equivalente a $96,7 \%$;

- A PCR surge como uma promissora possibilidade para o diagnóstico da neurocisticercose. 


\section{BLOCO II:}
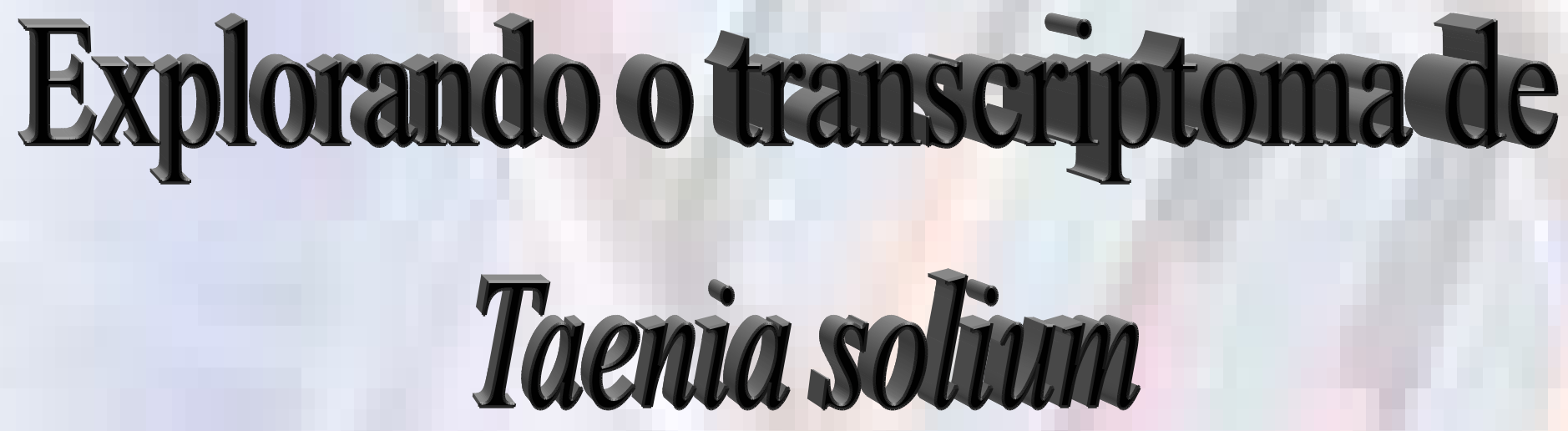


\section{MATERIAL E MÉTODOS}

\section{1 - Material Biológico Utilizado}

Para o desenvolvimento desta parte do trabalho utilizamos cisticercos dissecados de cérebros de porcos infectados (obtidos em Pirassununga - SP) e imediatamente congelados em nitrogênio líquido, para assegurar a preservação do RNA. Este material foi gentilmente cedido por nosso colaborador, Prof. Dr. Antônio A. M. Maia, do campus de Pirassununga da Universidade de São Paulo (USP).

\section{2 - Extração de RNA}

Os cisticercos foram utilizados como fonte para a extração de mRNA através do kit $\mu$ MACS mRNA Isolation Kit (Miltenyi Biotec - Alemanha), seguindo as recomendações do fabricante. O mRNA obtido foi eluído em um volume de aproximadamente $75 \mu \mathrm{l}$ e quantificado por leitura a $260 \mathrm{~nm}$ em espectrofotômetro U-3010 Hitachi (Tokyo, Japan). Posteriormente, alíquotas contendo $25 \mathrm{ng} / \mu \mathrm{l}$ de mRNA foram preparadas e armazenadas imediatamente $\mathrm{a}-80^{\circ} \mathrm{C}$. Estas alíquotas foram utilizadas na geração das primeiras seqüências parciais de genes transcritos (ESTs) deste parasita.

\section{3 - Descoberta gênica em $T$. solium}

A partir deste mRNA, utilizamos a técnica de ORESTES (Open Reading Frames ESTs - Dias Neto et al., 2000), para a determinação da seqüência nucleotídica de genes ativos nos cisticercos cerebrais.

Para isto, o cDNA foi sintetizado utilizando iniciadores aleatórios, disponíveis em nosso laboratório e usados anteriormente em projetos de descoberta gênica de outros organismos, comprovadamente limpos de contaminantes.

Os perfis de amplificação obtidos (Figura 15) foram avaliados em géis de agarose corados com brometo de etídio e clonados em vetores de seqüenciamento, conforme a seguir. Todas as minibibliotecas ORESTES que foram geradas neste projeto estão apresentadas na Tabela 3. 


\subsection{Clonagem das ORESTES}

\subsection{1 - Ligação e transformação}

Os perfis produzidos foram clonados em vetores de seqüenciamento pGEM utilizando o kit p-GEM T-Easy (Promega Corporation, Madison, USA), cuja estrutura está representada logo abaixo.

Figura 14 - Vetor de clonagem P-Gem T Easy Promega Corporation (Madison, USA). Na figura está representado o vetor completo, com todos os seus sítios de restrição do sítio múltiplo de clonagem.

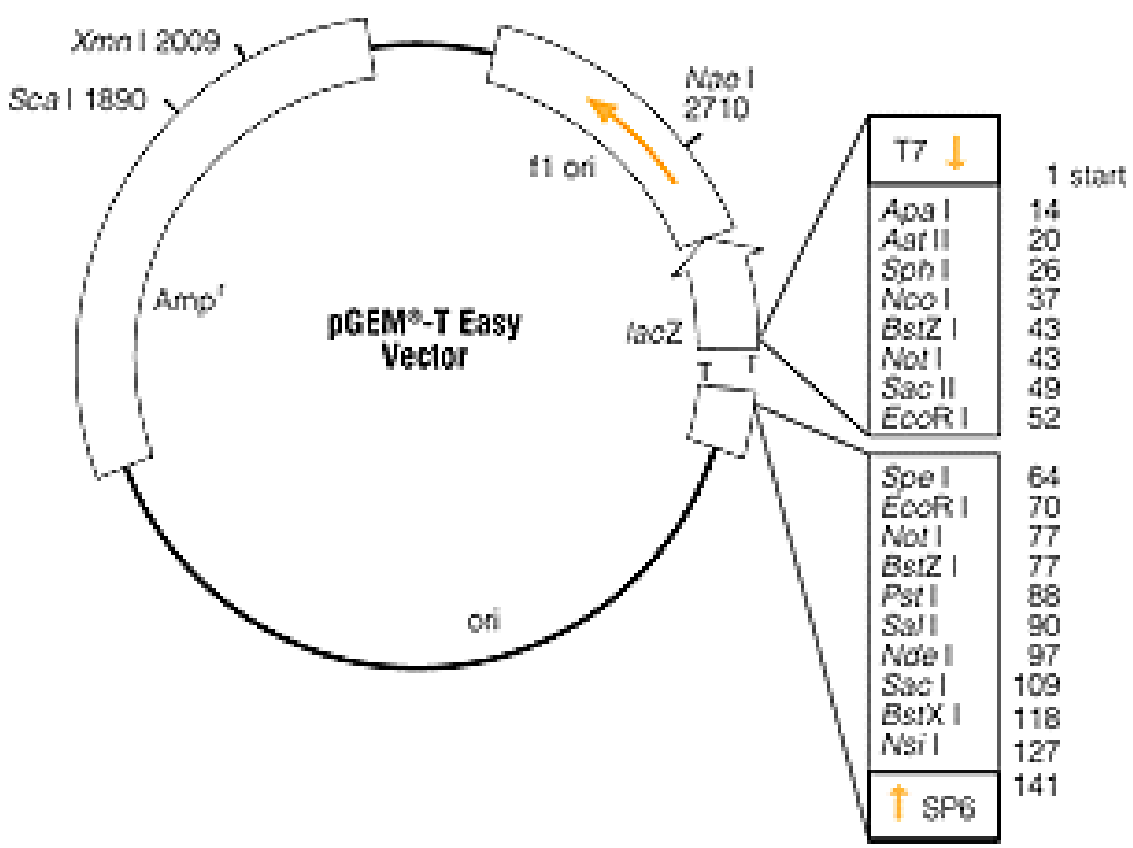

Os plasmídeos recombinantes foram usados na transformação de bactérias Escherichia coli (cepa DH10ß) quimiocompetentes para produção em larga escala dos moldes a serem seqüenciados. A transformação bacteriana se deu por choque térmico, onde um tubo contendo plasmídeos e células quimiocompetentes foi aquecido a $42^{\circ} \mathrm{C}$ durante $90 \mathrm{~s}$ e imediatamente colocado em gelo, sendo a ele acrescentado $600 \mu \mathrm{l}$ de meio S.O.C. ( $2 \%$ de triptona, $0.5 \%$ de extrato de levedura, 
$10 \mathrm{mM}$ de cloreto de sódio, $2.5 \mathrm{mM}$ de cloreto de potássio, $10 \mathrm{mM}$ de cloreto de magnésio, $10 \mathrm{mM}$ de sulfato de magnésio e $20 \mathrm{mM}$ de glicose); alternativamente, usamos $2 \mu \mathrm{l}$ dos produtos da ligação para proceder a uma eletroporação da mesma cepa de bactérias. A eletroporação foi conduzida em Eletroporador Multiporador (Eppendorf Scientific, Westbuty, New York, USA), utilizando cubetas de $1 \mathrm{~mm}$ (BioRad, Califórnia, USA) utilizando 1700 volts. As células transformadas foram recuperadas após o choque em $1 \mathrm{ml}$ de meio de cultura, sob agitação a 200 rpm por uma hora na temperatura de $37^{\circ} \mathrm{C}$. Após estes procedimentos, as bactérias foram plaqueadas para crescimento de 12 a 16 horas em meio de cultura LB-ágar ( $10 \mathrm{~g}$ de peptona, $5 \mathrm{~g}$ de extrato de levedura, $10 \mathrm{~g}$ de cloreto de sódio, $15 \mathrm{~g}$ de ágar) contendo ampicilina $100 \mu \mathrm{g} / \mathrm{ml}$, IPTG $20 \mu \mathrm{g} / \mathrm{ml}$ e X-Gal $40 \mu \mathrm{g} / \mathrm{ml}$. As colônias brancas foram retiradas do meio sólido e crescidas em

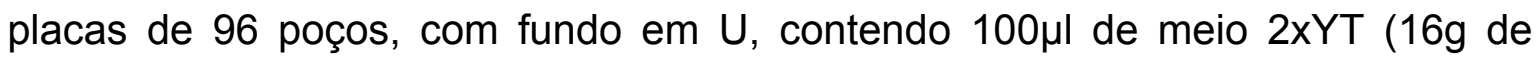
peptona, $10 \mathrm{~g}$ de extrato de levedura, $5 \mathrm{~g}$ de cloreto de sódio) com ampicilina $100 \mu \mathrm{g} / \mathrm{ml}$ por um período entre $12-16$ horas em estufa a $37^{\circ} \mathrm{C}$.

\section{4 - Preparo do DNA molde e seqüenciamento}

\section{A - PCR de colônia}

Para a maior parte das reações de seqüenciamento que realizamos, utilizamos como molde os produtos de PCR gerados a partir da amplificação dos insertos clonados nos plasmídeos P-Gem-T-Easy, utilizando iniciadores universais. Nesta etapa, $1 \mu \mathrm{l}$ de bactérias crescidas até sua saturação foi adicionado ao mix de PCR contendo 30mM Tris- $\mathrm{HCl}$ (pH 8.8); 15mM KCl Buffer;

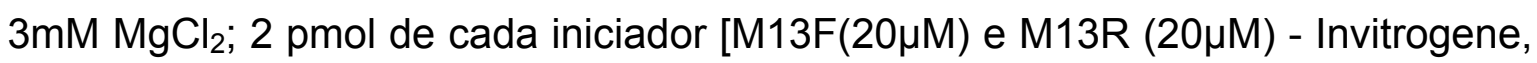
São Paulo, Brasil); 1875 pmol de dNTP's (Invitrogene, Califórnia, USA) e 1 U de Taq DNA polymerase (New England Biolabs; Beverly, MA). Os reagentes, com um volume final de $15 \mu \mathrm{l}$ foram incubados num termociclador MJ Research (Watertown, MA) PTC-100 Thermal cycler para amplificação segundo o seguinte protocolo: $95^{\circ} \mathrm{C}-3 \mathrm{~min} ; 95^{\circ} \mathrm{C}-40$ seg; $55^{\circ} \mathrm{C}-40$ seg; $72^{\circ} \mathrm{C}-55$ seg. A ciclagem foi repetida 35 vezes e os produtos obtidos, analisados por amostragem em gel de agarose a $1 \%$. 


\section{B - Extração dos Plasmídeos}

Alternativamente, seqüenciamos os plasmídeos diretamente após sua extração das bactérias recombinantes. No protocolo utilizado, empregamos o uso de lise alcalina clássica, envolvendo o uso de três soluções e subseqüente eluição do DNA plasmidiano. A solução I (GET) contém apenas tampão (Tris$\mathrm{HCl})$, EDTA e glicose. A solução II $(0,18 \mathrm{M} \mathrm{NaOH} / \mathrm{SDS} 1 \%)$ é ativa na lise; contém $\mathrm{NaOH}$, que atua na desnaturação parcial das proteínas presentes e SDS, um agente de solvatação que dissocia os componentes de membrana e se liga às proteínas facilitando a sua soltura do DNA plasmidial, o qual permanece no fundo da placa como pellet. O DNA nuclear da bactéria não se desliga das proteínas semidesnaturadas sendo descartado junto com elas. Posteriormente, o sal de K+ da solução III (KOAc 5M/ácido acético glacial) precipita prontamente, levando consigo o restante do DNA bacteriano e deixando o plasmídio aderido à membrana de sílica gel. Este último é finalmente eluído, o que pode ser feito com o uso de 1 volume de isopropanol ou 2 volumes de etanol, sendo posteriormente avaliado em gel de agarose $1 \%$.

\section{C - Reação de seqüenciamento}

O seqüenciamento para leitura no aparelho $A B I 3100$ foi feito utilizando-se o kit Big Dye Terminator - Applied Biosystems, em um volume final de reação de $10 \mu \mathrm{l}$, o qual era composto por 3,2 pmol de iniciador SP6, 1X Buffer Save \$ (200mM Tris- $\mathrm{HCl} \mathrm{pH}$ 9.0; $5 \mathrm{mM} \mathrm{MgCl}_{2}$ ) e $1 \mu \mathrm{l}$ do produto de PCR ou $1 \mu \mathrm{l}$ de plasmídeo diluído 1:20X. A ciclagem $(35 \mathrm{X})$ realizada no termociclador $\mathrm{MJ}$ Research PTC-100 Thermal cycler (Watertown, MA, USA) foi: $95^{\circ} \mathrm{C}-3 \mathrm{~min} ; 95^{\circ} \mathrm{C}$ 30seg; $55^{\circ} \mathrm{C}-15 \mathrm{seg} ; 60^{\circ} \mathrm{C}-4 \mathrm{~min}$.

O seqüenciamento para leitura no aparelho Mega Bace 1000 foi realizado no Depto de Microbiologia e Parasitologia da UFSC, utilizando-se o kit DYEnamic ET dye terminator - Amersham Pharmacia Biotech, em um volume final de reação

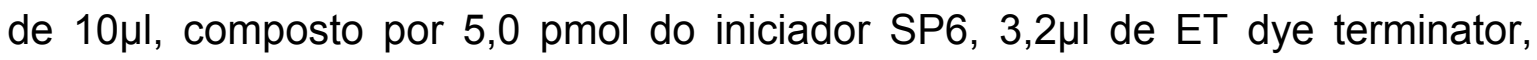
700ng de DNA e água q.s.p. 10 $\mu$ l. A ciclagem (35X) realizada em termociclador Eppendorf Scientific (Westbuty, New York, USA) foi a seguinte: $95^{\circ} \mathrm{C}-2 \mathrm{mim}$; $95^{\circ} \mathrm{C}-30$ seg; $55^{\circ} \mathrm{C}-15$ seg; $60^{\circ} \mathrm{C}-4 \mathrm{~min}$. 


\section{D - Preparo das amostras para o seqüenciamento}

Após a reação de seqüenciamento, as amostras foram precipitadas através de duas lavagens com álcool: isopropanol $75 \%$ e etanol $70 \%$ para seqüenciamento no $A B \mid 3100$, e duas lavagens com etanol $96 \%$ e $70 \%$ para seqüenciamento no Mega Bace 1000, para que o excesso de reagentes e os possíveis fluoróforos não incorporados na reação fossem eliminados e não interferissem na eletroforese. Para leitura no $A B \mid 3100$, as amostras foram ressuspendidas em $10 \mu \mathrm{l}$ de $\mathrm{Hi}$-Di Formamida e desnaturadas a $95^{\circ} \mathrm{C}$ durante 4 min, sendo imediatamente colocadas no gelo. Para o seqüenciamento no Mega Bace 1000, o volume de $8 \mu \mathrm{l}$ de loading buffer ( $70 \%$ de formamida, $1 \mathrm{M}$ de EDTA) foi adicionado a cada poço da placa, a qual foi devidamente selada e homogeneizada em vórtex antes de ser levada ao seqüenciador.

\section{5 - Seqüenciamento}

As amostras foram seqüenciadas nos aparelhos $A B I P R I S M^{\circledR} 3100$ Genetic Analyzer (Applied Biosystems, Foster City, USA) - disponível no Laboratório de Neurociências (LIM-27), IPq, HCFMUSP - e MegaBace 1000 (Amersham), do Departamento de Imunologia e Parasitologia da Universidade Federal de Santa Catarina (UFSC), em colaboração com os Profs. Dr. Edmundo C. Grisard e Dr. Mário Steindel.

\section{6 - Análises de Bioinformática}

As seqüências foram avaliadas em termos de qualidade (Phred scores) e similaridade com domínios protéicos específicos e com genes de outros organismos, utilizando-se bancos de dados internacionais.

O BLAST foi a ferramenta mais amplamente utilizada nestas análises. As seqüências obtidas foram comparadas com seqüências depositadas em bancos de DNA, usando o programa BLASTn (banco NR - não redundante; e banco dbEST - contendo ESTs de outros organismos) e usando o programa BLASTx (onde as seqüências são traduzidas nas seis possiveis molduras de leitura e comparadas com todas as seqüências protéicas depositadas em bancos públicos). 
Posteriormente, todas as seqüências geradas serão submetidas a um pipeline automatizado de bioinformática, gerando as análises finais e facilitando sua deposição em bancos de dados internacionais. 


\section{RESULTADOS}

\section{Seqüenciamento}

Nesta etapa foram geradas 20 mini-bibliotecas de cDNA de onde foram obtidas as primeiras 2880 ESTs de $T$. solium. Com isto, foi possível, pela primeira vez, investigar o perfil de genes ativos neste importante estádio evolutivo do parasita. A Figura 14, bem como a Tabela 3, mostram os perfis de amplificação de algumas mini-bibliotecas ORESTES geradas nesta etapa do trabalho.

Figura 15 - Perfis de amplificação de algumas mini-bibliotecas ORESTES. Gel de agarose $1 \%$ corado com brometo de etídio. A primeira linha contém o padrão de peso molecular (100pb) utilizado, enquanto que as canaletas 1-5 evidenciam as bibliotecas produzidas, utilizando, respectivamente, os seguintes iniciadores: PS0253, PS0259, PS0260, PS0263 e PS0264, conforme indicado na Tabela 3.

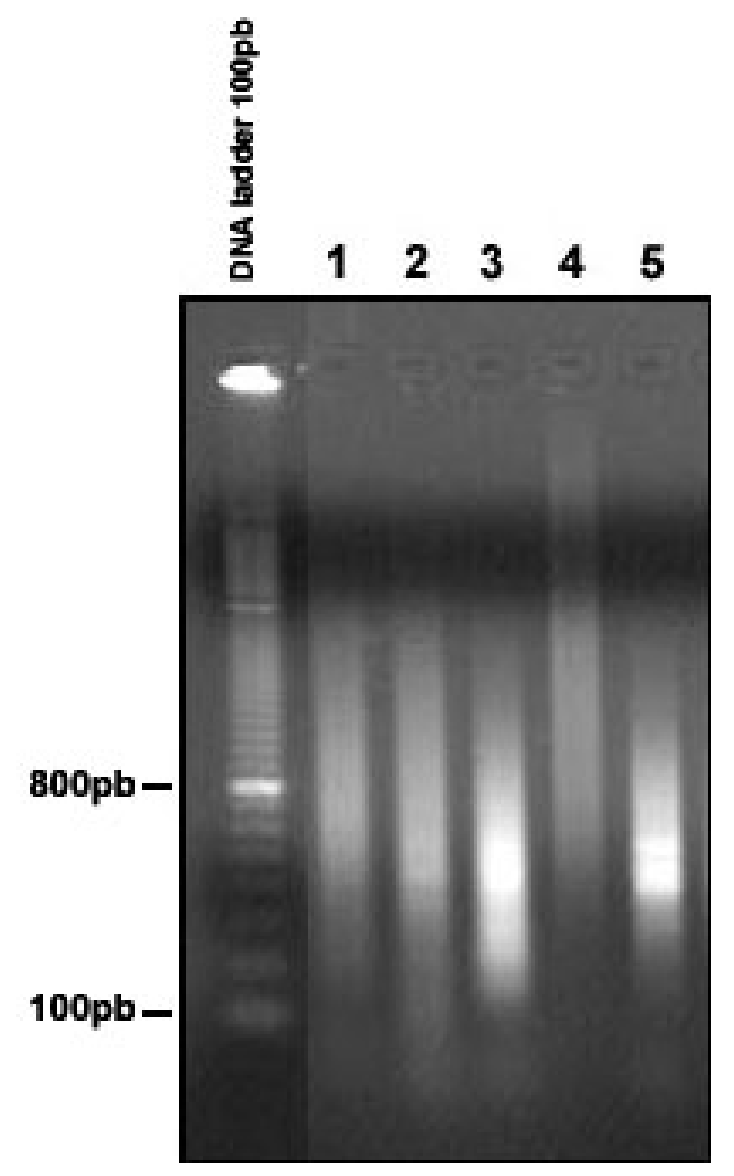


Tabela 3 - Mini-bibliotecas de ORESTES geradas. A última linha traz o total de seqüências geradas para cada biblioteca, todos os iniciadores utilizados e o número total de seqüências aproveitáveis.

\begin{tabular}{|c|c|c|c|c|}
\hline & \multirow{2}{*}{$\begin{array}{l}\text { Número da } \\
\text { Biblioteca }\end{array}$} & \multicolumn{2}{|c|}{ Iniciadores Utilizados } & \multirow{2}{*}{$\begin{array}{c}\text { Total de } \\
\text { seqüências }\end{array}$} \\
\hline & & Nome & Seqüência $\left(5^{\prime}>3^{\prime}\right)$ & \\
\hline & 01 & PS0264 & AGAAGAGGTTTCCACCGC & 192 \\
\hline & 02 & PS0259/PS0263 & $\begin{array}{l}\text { ACTGCGAAGCGGCTTCTT } \\
\text { GTGGGTTGACCGTGGCTT }\end{array}$ & 96 \\
\hline & 03 & PS0234/PS0159/PS0235/PS0259 & $\begin{array}{l}\text { TGTCTTTCCCTGCTGCTC } \\
\text { CCAGCCCCAGACACGGAC } \\
\text { TGCCTGCAGTCTTCCCGC } \\
\text { ACTGCGAAGCGGCTTCTT }\end{array}$ & 96 \\
\hline & 04 & PS0234/PS0159 & $\begin{array}{l}\text { TGTCTTTCCCTGCTGCTC } \\
\text { CCAGCCCCAGACACGGAC }\end{array}$ & 96 \\
\hline & 05 & PS0235 & TGCCTGCAGTCTTCCCGC & 96 \\
\hline & 06 & PS0259 & ACTGCGAAGCGGCTTCTT & 96 \\
\hline & 07 & PS0290 & TTCСТTTCTCСТСССАССТC & 96 \\
\hline & 08 & PS 0234 & TGTCTTTCCCTGCTGCTC & 96 \\
\hline & 09 & PS0235/PS0259/PS0289 & $\begin{array}{l}\text { TGCCTGCAGTCTTCCCGC } \\
\text { ACTGCGAAGCGGCTTCTT } \\
\text { TAAAGCCAAACCCCCGAC }\end{array}$ & 96 \\
\hline & 10 & PS $0259 /$ PS0289/PS0290/PS0151 & $\begin{array}{l}\text { ACTGCGAAGCGGCTTCTT } \\
\text { TAAAGCCAAACCCCCGAC } \\
\text { TTCCTCTCCTCCCACCTC } \\
\text { CGGGCTCCCTGCCCATGT }\end{array}$ & 96 \\
\hline & 11 & PS0290 & ТТССТСТССТСССАССССТС & 96 \\
\hline & 12 & PS0542/PS0543 & $\begin{array}{l}\text { AACCGGTCCTTCTCCAAC } \\
\text { GCAATGGTCCTGTCGGTT }\end{array}$ & 384 \\
\hline & 13 & PS0 544 & GACCAGGGCCCAGCATGT & 192 \\
\hline & 14 & PS0 546 & CGCTCACAACATGCACAG & 96 \\
\hline & 15 & PS0548/PS0549 & $\begin{array}{l}\text { GGCGGCACGAGGGCATGG } \\
\text { TTCCGGCCGCTTTTCATC }\end{array}$ & 288 \\
\hline & 16 & PS0550/PS0551 & $\begin{array}{l}\text { GTAGTGCAAACTGCAGCC } \\
\text { AAAACCCCCNCCTTTCCC }\end{array}$ & 96 \\
\hline & 17 & PS0552 & CTTGGAACGAGACGACCT & 192 \\
\hline & 18 & PS0 512 & TTGCCAGGCTCTCTACCT & 96 \\
\hline & 19 & PS0558 & TTACCGTGGAGACACCTG & 192 \\
\hline & 20 & PS0 560 & CTCGGGTTGACAACGGCT & 192 \\
\hline Total & 20 & 21 & 21 & 2880 \\
\hline
\end{tabular}




\section{Análise nos bancos de dados}

Após terem sido feitas as análises iniciais qualitativas, através da simples visualização dos cromatogramas, as seqüências produzidas durante o seqüenciamento foram avaliadas manualmente em bancos de dados utilizando programas de busca de similaridade entre seqüências por submissão das ESTs no formato FASTA extraído do seqüenciador, e aqui representado na Figura 16.

Figura 16 - Formato FASTA de uma seqüência.

$>$ TSC001-IPQ002-_B12_.G_04.ab1

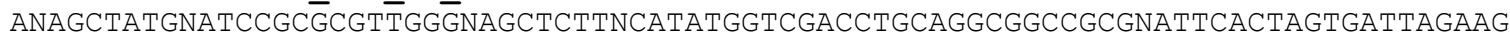
AGGTTTCCACCGCAGCAATCTCCTCCGCTTCCTCCACCTGTCGTTTGTAAGTCTTGATCTTCCCCTGAAGTTGGTCCACC AACTCTTGCAGACGGTCATAGTTCTTCTTGTCCTCATCCGCCTGCATGGTGACCTCCTTGAGACGACGATCAATCTTGCG GTAGTTCTTCTGAGTCTCGCCATGGCGACGCTGCTCGGCGTCCAACTCGGTCTCAAGTTCACGGACGCGTTGTTCCAGTT TGGCGAGTGCCTTCTTGCCGCCCTTCATTGCATNAGCCTCGGCTTCTTCCAGACGAACTNGGAGCTCCTTCACCTGTTGC TCGG

\section{Análises utilizando o programa BLAST}

A comparação de seqüências nucleotídicas ou de proteínas é uma ferramenta poderosa que permite encontrar similaridade entre estas seqüências dando poder aos pesquisadores para sugerir a função de proteínas ou de genes descobertos em um organismo, predizer novos membros de famílias gênicas e explorar evolutivamente as relações entre os mais diversos organismos.

Deste modo, antes de implementarmos as análises automatizadas (a serem realizadas em colaboração com o núcleo de bioinformática do Dr. Paulo Oliveira, InCor) realizamos, para algumas das ESTs geradas, análises comparativas usando o programa BLAST (http://www.ncbi.nlm.nih.gov/BLAST). Nesta análise, fizemos buscas de similaridade das seqüências estudadas com todas as outras depositadas nesse banco de dados, as quais são oriundas dos organismos estudados até o momento. A Figura 17 ilustra uma dessas análises. 
Figura 17 - Exemplo de análise de uma EST de T. solium utilizando o programa BlastX (http://www.ncbi.nlm.nih.gov/).

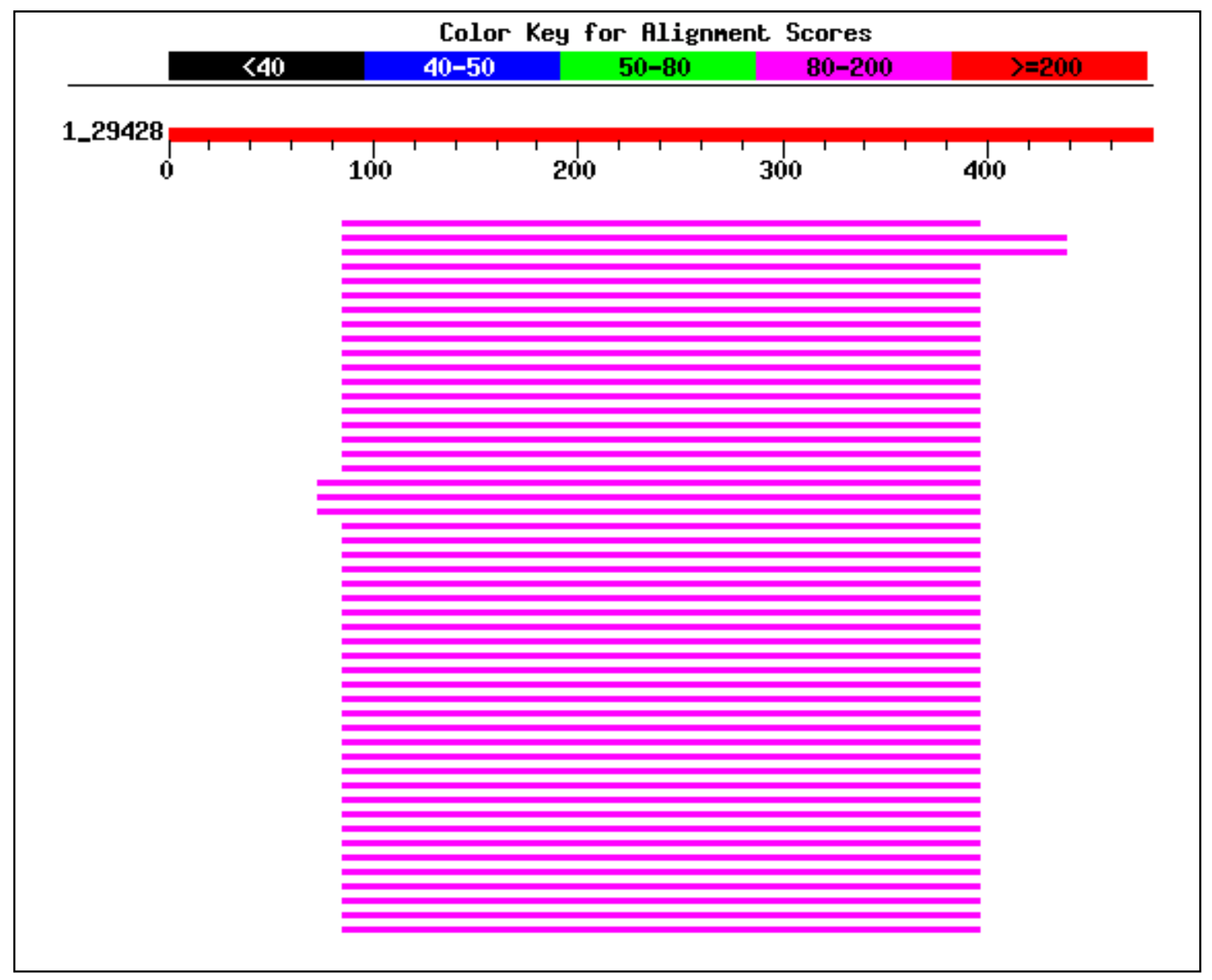

\footnotetext{
>gi|11276951|pir||A59287 myosin heavy chain - fluke (Schistosoma mansoni) (strain Brazilian LE) gi|161044|gb|AAA29905.1I myosin heavy chain Length $=1940$

Score $=183$ bits $(464)$, Expect $=2 e-45$

Identities $=84 / 104(80 \%)$, Positives $=96 / 104 \quad(92 \%)$

Frame $=-3$

Query: 397 EKSRVTSQMKGERNFHIFYQILSDYGKKYHDKLLVSADPALYSFINQGELTIDGVDDAEE 218 EKSRV SQMKGERN+HIFYQ+LS YG KYHDKLLV DPALYSFINQGELTIDGVDD+EE

Sbjct: 262 EKSRVVSQMKGERNYHIFYQLLSTYGSKYHDKLLVQTDPALYSFINQGELTIDGVDDSEE 321

Query: 217 MKITDEAIDILGFSNDERMSMFKCTTSVINMGEMKEKQRPREEQ 86 $\mathrm{MK}+\mathrm{DEA}++\mathrm{LGF}++\mathrm{DE}++\mathrm{S}+\mathrm{FKCTTS}+$ NMGEMKFKQRPREEQ

Sbjct: 322 MKLCDEAFEVLGFNDDEKLSLFKCTTSICNMGEMKFKQRPREEQ 365
}

A seqüência de estudo (query) é representada pela barra vermelha numerada no topo da Figura 17. A similaridade encontrada nos bancos de dados 
é apresentada logo abaixo da barra vermelha, em cores que indicam o nível de similaridade observada (neste caso, barras rosa); cada uma dessas seqüências alinhadas é chamada sbjct. As seqüências encontradas nos bancos de dados são distribuídas no diagrama, estando as mais similares colocadas mais próximas ao query. No caso da figura acima, demonstramos a identificação de um fragmento do gene de $T$. solium que aparentemente codifica para a miosina. Notamos que a maior similaridade encontrada foi com a miosina de S. mansoni, um outro parasita (trematódeo) de importância médica. A identidade observada entre a miosina destes dois organismos é de cerca de $80 \%$ nesta região da proteína.

\section{Descoberta gênica em $T$. solium}

Abaixo, representado na Tabela 4, encontram-se algumas das proteínas identificadas através da análise das ESTs de $T$. solium que geramos.

Tabela 4 - Alguns resultados das análises utilizando programas como 0 BlastN e o BlastX.

\begin{tabular}{|c|c|c|c|c|c|c|}
\hline Mini-biblioteca & Gene & $\begin{array}{l}\text { Tamanho da } \\
\text { EST (pb) }\end{array}$ & Algorítimo & Score & e-value & Identidades \\
\hline $\begin{array}{l}\text { TSC001-IPQ002 } \\
\text { A10 }\end{array}$ & $\begin{array}{c}\text { N-methyl-D-aspartate } \\
\text { receptor associated protein } \\
\text { CG3798-PA Drosophila } \\
\text { melanogaster }\end{array}$ & 788 & BlastX & $\begin{array}{l}84.3 \\
(207)\end{array}$ & $2 \mathrm{e}-15$ & $59 / 149(39 \%)$ \\
\hline $\begin{array}{c}\text { TSC001-IPQ002 } \\
\text { B2 }\end{array}$ & $\begin{array}{c}\text { Similar to MOP } 3 \\
\text { Mus musculus - strawberry } \\
\text { notch homolog } 1\end{array}$ & 652 & BlastX & $\begin{array}{l}49.3 \\
(116)\end{array}$ & $5 e-05$ & $40 / 128(31 \%)$ \\
\hline $\begin{array}{c}\text { TSC001-IPQ002 } \\
\text { B6 }\end{array}$ & $\begin{array}{l}\text { Protease, serine } \\
\text { Mus musculus }\end{array}$ & 646 & BlastX & $\begin{array}{c}187 \\
(474)\end{array}$ & $2 e-46$ & $90 / 134(67 \%)$ \\
\hline $\begin{array}{c}\text { TSC001-IPQ002 } \\
\text { B7 }\end{array}$ & $\begin{array}{c}\text { Predicted helicase } \\
\text { Azotobacter vinelandii }\end{array}$ & 574 & BlastX & $\begin{array}{l}49.3 \\
(116)\end{array}$ & $5 e-05$ & $\begin{array}{l}29 / 77 \\
(37 \%) \\
\end{array}$ \\
\hline $\begin{array}{c}\text { TSC001-IPQ002 } \\
\text { B10 } \\
\end{array}$ & $\begin{array}{c}\text { Taenia solium mitochondrial } \\
\text { DNA }\end{array}$ & 447 & tBlastX & $\begin{array}{c}130 \\
(278) \\
\end{array}$ & $3 e-28$ & $55 / 55(100 \%)$ \\
\hline $\begin{array}{l}\text { TSC001-IPQ002 } \\
\text { B12 }\end{array}$ & $\begin{array}{l}\text { myosin heavy chain - fluke } \\
\text { Schistosoma mansoni }\end{array}$ & 770 & BlastX & $\begin{array}{l}170 \\
(431)\end{array}$ & $9 e-43$ & $83 / 110(75 \%)$ \\
\hline $\begin{array}{l}\text { TSC001-IPQ002 } \\
\text { C07 }\end{array}$ & $\begin{array}{c}\text { Putative Oxygen- } \\
\text { Independent } \\
\text { Coproporphyrinogen III } \\
\text { Oxidase Protein } \\
\text { Sinorhizobium meliloti }\end{array}$ & 680 & BlastX & $\begin{array}{c}103 \\
(257)\end{array}$ & $3 e-21$ & $51 / 68(75 \%)$ \\
\hline $\begin{array}{l}\text { TSC001-IPQ002 } \\
\text { D06 }\end{array}$ & $\begin{array}{l}\text { VAT 1 (vesicle amine } \\
\text { transport protein 1) } \\
\text { Homo sapiens }\end{array}$ & 706 & BlastX & $\begin{array}{c}78.2 \\
(191)\end{array}$ & $1 e-13$ & $48 / 137(35 \%)$ \\
\hline
\end{tabular}




\begin{tabular}{|c|c|c|c|c|c|c|}
\hline $\begin{array}{l}\text { TSC001-IPQ002 } \\
\text { D07 }\end{array}$ & Actin gene Taenia solium & 686 & $\begin{array}{l}\text { BlastN/ } \\
\text { BlastX }\end{array}$ & $\begin{array}{c}119 \\
(298)\end{array}$ & $6 e-55$ & $58 / 63(92 \%)$ \\
\hline $\begin{array}{c}\text { TSC001-IPQ002 } \\
\text { E09 }\end{array}$ & $\begin{array}{c}\text { Hypothetical protein } \\
\text { CBG16504 } \\
\text { Caenorhabditis briggsae }\end{array}$ & 546 & BlastX & $\begin{array}{l}48.9 \\
(115)\end{array}$ & $5 e-05$ & $40 / 125(32 \%)$ \\
\hline $\begin{array}{c}\text { TSC001-IPQ002 } \\
\text { H04 }\end{array}$ & $\begin{array}{l}\text { Paramyosin (PMY) (Antigen } \\
\text { B) Taenia solium }\end{array}$ & 731 & $\begin{array}{l}\text { BlastN/ } \\
\text { BlastX }\end{array}$ & $\begin{array}{c}194 \\
(492)\end{array}$ & $7 e-50$ & 104/116 (89\%) \\
\hline $\begin{array}{l}\text { TSC002-IPQ008 } \\
\text { E09 }\end{array}$ & $\begin{array}{c}\text { Fructose-bisphosphate } \\
\text { aldolase Echinococcus } \\
\text { multilocularis }\end{array}$ & 701 & BlastX & $\begin{array}{c}164 \\
(416)\end{array}$ & $1 e-39$ & $85 / 123(69 \%)$ \\
\hline $\begin{array}{c}\text { TSC002-IPQ008 } \\
\text { H04 }\end{array}$ & $\begin{array}{l}\text { Hordeum vulgare naat-B } \\
\text { and naat-A genes for } \\
\text { nicotianamine } \\
\text { aminotransferase }\end{array}$ & 660 & tBlastX & $\begin{array}{l}48.3 \\
(99)\end{array}$ & $1 \mathrm{e}-06$ & 24/61 (39\%) \\
\hline $\begin{array}{c}\text { TSC002-IPQ008 } \\
\text { H06 }\end{array}$ & $\begin{array}{c}\text { NAD-specific glutamate } \\
\text { dehydrogenase (NAD-GDH) } \\
\text { Neurospora crassa }\end{array}$ & 720 & BlastX & $\begin{array}{c}149 \\
(375)\end{array}$ & $6 e-35$ & 71/104 (68\%) \\
\hline $\begin{array}{c}\text { TSC002-IPQ008 } \\
\text { H11 }\end{array}$ & $\begin{array}{l}\text { neurofilament triplet } \mathrm{H} 1 \text {-like } \\
\text { protein Regina ranavirus }\end{array}$ & 462 & BlastX & $\begin{array}{c}47.8 \\
(112)\end{array}$ & $6 e-05$ & 19/62 (30\%) \\
\hline $\begin{array}{l}\text { TSC001-IPQ005 } \\
\text { C07 }\end{array}$ & $\begin{array}{l}\text { nuclear antigen EBNA1 } \\
\text { Human herpesvirus } 4\end{array}$ & 912 & BlastX & $\begin{array}{c}111 \\
(277)\end{array}$ & $2 e-23$ & $76 / 231(32 \%)$ \\
\hline $\begin{array}{l}\text { TSC001-IPQ005 } \\
\text { D10 }\end{array}$ & $\begin{array}{l}\text { Dihydrolipoamide S- } \\
\text { acetyltransferase } \\
\text { C.elegans }\end{array}$ & 680 & BlastX & $\begin{array}{l}67.0 \\
(162)\end{array}$ & $3 e-10$ & $29 / 58(50 \%)$ \\
\hline $\begin{array}{c}\text { TSCMIX } \\
(004+005+006) \\
\text { A09 }\end{array}$ & $\begin{array}{l}\text { Similar to Ac1147 } \\
\text { Mus musculus }\end{array}$ & 780 & BlastX & $\begin{array}{l}97.4 \\
(241)\end{array}$ & $1 e-30$ & $48 / 54(88 \%)$ \\
\hline $\begin{array}{c}\text { TSCMIX } \\
(004+005+006) \\
\text { A10 }\end{array}$ & $\begin{array}{l}\text { lipopolysaccharide } \\
\text { biosynthesis protein } \\
\text { Thermotoga maritima }\end{array}$ & 406 & BlastX & $\begin{array}{l}57.4 \\
(137)\end{array}$ & $5 e-08$ & $24 / 67(35 \%)$ \\
\hline $\begin{array}{c}\text { TSCMIX } \\
(004+005+006) \\
\text { A11 }\end{array}$ & $\begin{array}{c}\text { COENZYME F390 } \\
\text { SYNTHETASE II } \\
\text { Wolinella succinogenes }\end{array}$ & 432 & BlastX & $\begin{array}{c}112 \\
(279)\end{array}$ & $7 e-24$ & $51 / 124(41 \%)$ \\
\hline $\begin{array}{c}\text { TSCMIX } \\
(004+005+006) \\
\text { B04 }\end{array}$ & $\begin{array}{c}\text { Pseudomonas syringae pv. } \\
\text { tomato str. DC } 3000 \text { section } \\
4 \text { of } 21 \text { of the complete } \\
\text { genome }\end{array}$ & 360 & tBlastX & $\begin{array}{c}136 \\
(291)\end{array}$ & $4 e-30$ & $53 / 53(100 \%)$ \\
\hline $\begin{array}{c}\text { TSCMIX } \\
(004+005+006) \\
\text { C03 }\end{array}$ & $\begin{array}{c}\text { Outer membrane lipoprotein } \\
\text { sorting protein } \\
\text { Burkholderia fungorum - } \\
\text { Bactéria }\end{array}$ & 600 & BlastX & $\begin{array}{l}53.1 \\
(126)\end{array}$ & $1 e-14$ & $25 / 53(47 \%)$ \\
\hline $\begin{array}{c}\text { TSCMIX } \\
(004+005+006) \\
\text { D06 } \\
\end{array}$ & MBCTL1 & 600 & BlastX & $\begin{array}{c}78.2 \\
(191)\end{array}$ & $9 e-14$ & $53 / 132(40 \%)$ \\
\hline $\begin{array}{c}\text { TSCMIX } \\
(004+005+006) \\
\text { D11 }\end{array}$ & $\begin{array}{c}\text { Molecular chaperone, } \\
\text { HSP90 family } \\
\text { Pseudomonas fluorescens } \\
\text { PfO-1 }\end{array}$ & 360 & BlastX & $\begin{array}{l}89.0 \\
(219)\end{array}$ & $2 e-17$ & $44 / 44(100 \%)$ \\
\hline $\begin{array}{l}\text { TSC007-IPQ012 } \\
\text { B01 }\end{array}$ & $\begin{array}{l}\text { Heat shock protein } \\
\text { C. elegans }\end{array}$ & 476 & tBlastX & $\begin{array}{c}75.3 \\
(158)\end{array}$ & $3 e-25$ & $30 / 44(68 \%)$ \\
\hline $\begin{array}{l}\text { TSC008-IPQ013 } \\
\text { C01 }\end{array}$ & $\begin{array}{c}\text { VMP3 protein } \\
\text { Volvox carterif. nagariensis }\end{array}$ & 600 & BlastX & $\begin{array}{c}76.6 \\
(187)\end{array}$ & $3 e-13$ & $49 / 122(40 \%)$ \\
\hline
\end{tabular}




\begin{tabular}{|c|c|c|c|c|c|c|}
\hline $\begin{array}{c}\text { TSC008-IPQ013 } \\
\text { C02 }\end{array}$ & $\begin{array}{c}\text { Tubulin, alpha } 2 \\
\text { Danio rerio }\end{array}$ & 420 & BlastX & $\begin{array}{c}150 \\
(379)\end{array}$ & $8 e-36$ & $75 / 92(81 \%)$ \\
\hline $\begin{array}{l}\text { TSC008-IPQ013 } \\
\text { C05 }\end{array}$ & $\begin{array}{c}\text { Hypothetical protein } \\
\text { Oenothera elata subsp } \\
\text { hookeri }\end{array}$ & 441 & BlastX & $\begin{array}{l}94.4 \\
(233)\end{array}$ & $6 e-19$ & $41 / 42(97 \%)$ \\
\hline $\begin{array}{c}\text { TSC008-IPQ013 } \\
\text { C06 }\end{array}$ & $\begin{array}{c}\text { Ankyrin - related protein } \\
\text { C. elegans }\end{array}$ & 600 & BlastX & $\begin{array}{l}86.7 \\
(213)\end{array}$ & $3 e-16$ & $42 / 72(58 \%)$ \\
\hline $\begin{array}{l}\text { TSC008-IPQ013 } \\
\text { C09 }\end{array}$ & $\begin{array}{l}\text { Antrodia camphorata partial } \\
\text { mnsod gene for manganese } \\
\text { superoxide dismutase exons } \\
1-3\end{array}$ & 540 & BlastN & $\begin{array}{l}91.7 \\
(46)\end{array}$ & $1 e-15$ & $56 / 60(93 \%)$ \\
\hline $\begin{array}{c}\text { TSC008-IPQ013 } \\
\text { D04 }\end{array}$ & $\begin{array}{l}\text { Cell wall surface anchor } \\
\text { family protein } \\
\text { Streptococcus pneumoniae }\end{array}$ & 664 & BlastX & $\begin{array}{l}88.2 \\
(217)\end{array}$ & $1 e-16$ & $67 / 151(44 \%)$ \\
\hline $\begin{array}{l}\text { TSC008-IPQ013 } \\
\text { D08 }\end{array}$ & $\begin{array}{c}\text { Dynein, cytoplasmic, heavy } \\
\text { chain } 1 \\
\text { Rattus norvegicus }\end{array}$ & 540 & BlastX & $\begin{array}{c}130 \\
(328)\end{array}$ & $1 \mathrm{e}-29$ & $66 / 106(62 \%)$ \\
\hline $\begin{array}{l}\text { TSC008-IPQ013 } \\
\text { E03 }\end{array}$ & $\begin{array}{l}\text { Phosphoenolpyruvate } \\
\text { carboxykinase } \\
\text { Schistosoma mansoni }\end{array}$ & 469 & BlastX & $\begin{array}{c}152 \\
(383)\end{array}$ & $3 e-36$ & $66 / 86(76 \%)$ \\
\hline $\begin{array}{c}\text { TSC008-IPQ013 } \\
\text { E05 }\end{array}$ & $\begin{array}{c}\text { Super cysteine rich protein } \\
\text { Homo sapiens }\end{array}$ & 420 & BlastX & $\begin{array}{l}71.6 \\
(174)\end{array}$ & $4 e-12$ & $24 / 35(68 \%)$ \\
\hline $\begin{array}{l}\text { TSC008-IPQ013 } \\
\text { F02 }\end{array}$ & $\begin{array}{c}\text { metastasis associated gene } \\
1 \text { protein } \\
\text { Homo sapiens }\end{array}$ & 600 & BlastX & $\begin{array}{l}85.1 \\
(209)\end{array}$ & $5 e-26$ & $38 / 65(58 \%)$ \\
\hline $\begin{array}{l}\text { TSC008-IPQ013 } \\
\text { G06 }\end{array}$ & $\begin{array}{c}\text { CG33087-PC } \\
\text { Drosophila melanogaster }\end{array}$ & 420 & BlastX & $\begin{array}{c}71.2 \\
(173)\end{array}$ & $6 e-12$ & $34 / 78(43 \%)$ \\
\hline $\begin{array}{l}\text { TSC008-IPQ013 } \\
\text { G08 }\end{array}$ & $\begin{array}{c}\text { Choline/ethanolamine } \\
\text { kinase } \\
\text { Drosophila melanogaster }\end{array}$ & 600 & BlastX & $\begin{array}{l}63.9 \\
(154)\end{array}$ & $1 e-09$ & $31 / 73(42 \%)$ \\
\hline $\begin{array}{c}\text { TSC008-IPQ013 } \\
\text { H04 }\end{array}$ & $\begin{array}{l}\text { CGMP-dependent protein } \\
\text { kinase } \\
\text { Drosophila melanogaster }\end{array}$ & 540 & BlastX & $\begin{array}{l}95.9 \\
(237)\end{array}$ & $4 e-19$ & $54 / 110(49 \%)$ \\
\hline $\begin{array}{c}\text { TSC008-IPQ013 } \\
\text { H10 }\end{array}$ & $\begin{array}{l}\text { Connectin 3B } \\
\text { Chicken } \\
\text { Gallus gallus }\end{array}$ & 648 & BlastX & $\begin{array}{l}47.8 \\
(112)\end{array}$ & $2 e-04$ & $41 / 124(33 \%)$ \\
\hline $\begin{array}{l}\text { TSC011-IPQ014 } \\
\text { A09 }\end{array}$ & $\begin{array}{c}\text { integrin beta chain precursor } \\
\text { - fruit fly } \\
\text { Drosophila melanogaster }\end{array}$ & 480 & BlastX & $\begin{array}{c}78.2 \\
(191)\end{array}$ & $6 e-14$ & $35 / 75(46 \%)$ \\
\hline $\begin{array}{c}\text { TSC011-IPQ014 } \\
\text { A11 }\end{array}$ & $\begin{array}{c}\text { KIAA0100 gene product } \\
\text { Homo sapiens }\end{array}$ & 621 & BlastX & $\begin{array}{l}59.7 \\
(143)\end{array}$ & $4 e-08$ & $36 / 110(32 \%)$ \\
\hline $\begin{array}{l}\text { TSC011-IPQ014 } \\
\text { B07 }\end{array}$ & $\begin{array}{l}\text { COG1674: DNA segregation } \\
\text { ATPase FtsK/SpollIE and } \\
\text { related proteins } \\
\text { Ralstonia eutropha JMP134 }\end{array}$ & 480 & BlastX & $\begin{array}{l}89.4 \\
(220)\end{array}$ & $3 e-17$ & $49 / 72(68 \%)$ \\
\hline $\begin{array}{c}\text { TSC011-IPQ014 } \\
\text { B09 }\end{array}$ & desmoyokin Mus musculus & 514 & BlastX & $\begin{array}{l}68.2 \\
(165)\end{array}$ & $7 e-11$ & $42 / 117(35 \%)$ \\
\hline $\begin{array}{c}\text { TSC011-IPQ014 } \\
\text { B12 }\end{array}$ & $\begin{array}{c}\text { chromosome } 14 \text { open } \\
\text { reading frame } 78 \text { Homo } \\
\text { sapiens }\end{array}$ & 469 & BlastX & $\begin{array}{l}69.3 \\
(168)\end{array}$ & $3 e-11$ & 49/126 (38\%) \\
\hline $\begin{array}{l}\text { TSC011-IPQ014 } \\
\text { C09 }\end{array}$ & $\begin{array}{c}\text { FAS associated factor } 1 \\
\text { C. elegans }\end{array}$ & 540 & BlastX & $\begin{array}{l}71.2 \\
(173)\end{array}$ & $1 e-11$ & $36 / 96(37 \%)$ \\
\hline $\begin{array}{c}\text { TSC011-IPQ014 } \\
\text { D02 }\end{array}$ & $\begin{array}{c}\text { Atrophin-1 } \\
\text { Hylobates lar } \\
\end{array}$ & 617 & BlastX & $\begin{array}{l}49.7 \\
(117)\end{array}$ & $4 e-05$ & $48 / 134(35 \%)$ \\
\hline $\begin{array}{c}\text { TSC011-IPQ014 } \\
\text { D04 }\end{array}$ & $\begin{array}{l}\text { unnamed protein product } \\
\text { Tetraodon nigroviridis }\end{array}$ & 621 & BlastX & $\begin{array}{l}57.0 \\
(136)\end{array}$ & $3 e-07$ & $48 / 144(33 \%)$ \\
\hline
\end{tabular}




\begin{tabular}{|c|c|c|c|c|c|c|}
\hline $\begin{array}{c}\text { TSC011-IPQ014 } \\
\text { E01 }\end{array}$ & $\begin{array}{c}\text { Mucin } 2 \\
\text { Homo sapiens }\end{array}$ & 600 & BlastX & $\begin{array}{l}57.4 \\
(137)\end{array}$ & $1 e-07$ & $42 / 135(31 \%)$ \\
\hline $\begin{array}{l}\text { TSC011-IPQ014 } \\
\text { E02 }\end{array}$ & $\begin{array}{c}\text { Twitchin } \\
\text { Mytilus galloprovincialis - } \\
\text { molusco }\end{array}$ & 676 & BlastX & $\begin{array}{c}106 \\
(264)\end{array}$ & $5 e-22$ & $48 / 102(47 \%)$ \\
\hline $\begin{array}{c}\text { TSC011-IPQ014 } \\
\text { E08 }\end{array}$ & $\begin{array}{c}\text { Phospholipase C beta } \\
\text { Lytechinus pictus - } \\
\text { equinodermo }\end{array}$ & 600 & BlastX & $\begin{array}{c}170 \\
(430)\end{array}$ & $2 e-41$ & $88 / 126(69 \%)$ \\
\hline $\begin{array}{l}\text { TSC011-IPQ014 } \\
\text { F04 }\end{array}$ & $\begin{array}{c}\text { Titin } \\
\text { Oryctolagus cuniculus - } \\
\text { coelho }\end{array}$ & 564 & BlastX & $\begin{array}{l}54.3 \\
(129)\end{array}$ & $1 e-06$ & $30 / 68(44 \%)$ \\
\hline $\begin{array}{c}\text { TSC011-IPQ014 } \\
\text { F05 }\end{array}$ & $\begin{array}{l}\text { Hypothetical protein } \\
\text { C. briggsae }\end{array}$ & 499 & BlastX & $\begin{array}{c}130 \\
(328)\end{array}$ & $9 e-30$ & $64 / 108(59 \%)$ \\
\hline $\begin{array}{l}\text { TSC011-IPQ014 } \\
\text { F12 }\end{array}$ & $\begin{array}{c}\text { CG12522-PA } \\
\text { Drosophila melanogaster }\end{array}$ & 412 & BlastX & $\begin{array}{l}49.7 \\
(117)\end{array}$ & $2 e-05$ & $40 / 100(40 \%)$ \\
\hline $\begin{array}{l}\text { TSC011-IPQ014 } \\
\text { G02 }\end{array}$ & Loricrin Mus musculus & 503 & BlastX & $\begin{array}{c}67.4 \\
(163)\end{array}$ & $1 e-10$ & $39 / 96(40 \%)$ \\
\hline $\begin{array}{l}\text { TSC011-IPQ014 } \\
\text { G06 }\end{array}$ & $\begin{array}{c}\text { RNA helicase II/Gu } \\
\text { Xenopus laevis }\end{array}$ & 558 & BlastX & $\begin{array}{c}107 \\
(268) \\
\end{array}$ & $1 \mathrm{e}-22$ & $53 / 119(44 \%)$ \\
\hline $\begin{array}{l}\text { TSC011-IPQ014 } \\
\text { G07 }\end{array}$ & $\begin{array}{c}\text { Putative } 60 \text { S ribossomal } \\
\text { L28 protein } \\
\text { Oryza sativa }\end{array}$ & 479 & BlastX & $\begin{array}{c}141 \\
(355)\end{array}$ & $5 e-33$ & $69 / 91(75 \%)$ \\
\hline $\begin{array}{c}\text { TSC011-IPQ014 } \\
\text { H01 }\end{array}$ & $\begin{array}{c}\text { Ubiquitin ligase E3 (1E376) } \\
\text { C. elegans }\end{array}$ & 591 & BlastX & $\begin{array}{l}45.4 \\
(106)\end{array}$ & $5 e-05$ & $18 / 30(60 \%)$ \\
\hline $\begin{array}{c}\text { TSC011-IPQ014 } \\
\text { H02 }\end{array}$ & $\begin{array}{l}\text { GRL-25 protein } \\
\text { C. elegans }\end{array}$ & 600 & BlastX & $\begin{array}{l}50.1 \\
(118)\end{array}$ & $3 e-05$ & $50 / 184(27 \%)$ \\
\hline $\begin{array}{c}\text { TSC011-IPQ014 } \\
\text { H05 }\end{array}$ & $\begin{array}{c}\text { Actin } 1 \\
\text { Echinococcus granulosus }\end{array}$ & 660 & BlastX & $\begin{array}{l}84.0 \\
(206)\end{array}$ & $2 e-27$ & $39 / 51(76 \%)$ \\
\hline $\begin{array}{c}\text { TSC011-IPQ014 } \\
\text { H10 }\end{array}$ & $\begin{array}{c}\text { ORF64c } \\
\text { Pinus koraiensis }\end{array}$ & 564 & BlastX & $\begin{array}{c}115 \\
(288)\end{array}$ & $5 e-25$ & $58 / 68(85 \%)$ \\
\hline $\begin{array}{c}\text { TSC011-IPQ014 } \\
\text { H11 }\end{array}$ & $\begin{array}{c}\text { CG14207-PA } \\
\text { Drosophila melanogaster }\end{array}$ & 660 & BlastX & $\begin{array}{l}59.7 \\
143)\end{array}$ & $5 e-08$ & $34 / 85(40 \%)$ \\
\hline $\begin{array}{l}\text { TSCMIX-IPQ015 } \\
\text { A09 }\end{array}$ & $\begin{array}{c}\text { Unknown NEM } 316 \\
\text { Streptococcus agalactiae }\end{array}$ & 420 & BlastX & $\begin{array}{l}55.8 \\
(133)\end{array}$ & $3 e-07$ & $34 / 58(58 \%)$ \\
\hline $\begin{array}{l}\text { TSCMIX-IPQ015 } \\
\text { B10 }\end{array}$ & $\begin{array}{c}\text { Calpain } \\
\text { Xenopus laevis }\end{array}$ & 300 & BlastX & $\begin{array}{l}74.7 \\
(182)\end{array}$ & $5 e-13$ & $33 / 45(73 \%)$ \\
\hline $\begin{array}{l}\text { TSCMIX-IPQ015 } \\
\text { C04 }\end{array}$ & $\begin{array}{c}\text { Echicetin A-chain } \\
\text { Echis carinatus - serpentes }\end{array}$ & 360 & BlastN & $\begin{array}{l}81.8 \\
(41)\end{array}$ & $9 e-13$ & $58 / 64(90 \%)$ \\
\hline $\begin{array}{l}\text { TSCMIX-IPQ015 } \\
\text { C05 }\end{array}$ & $\begin{array}{l}\text { Hypothetical protein ORF-91 } \\
\text { phage } 434\end{array}$ & 360 & BlastX & $\begin{array}{l}54.7 \\
(130)\end{array}$ & $6 e-07$ & $24 / 39(61 \%)$ \\
\hline $\begin{array}{l}\text { TSCMIX-IPQ015 } \\
\text { D01 }\end{array}$ & $\begin{array}{l}\text { High molecular weight basic } \\
\text { nuclear protein } \\
\text { Pseudopleuronectes } \\
\text { americanus - peixe } \\
\text { teleósteo }\end{array}$ & 420 & BlastX & $\begin{array}{l}48.9 \\
(115)\end{array}$ & $3 e-05$ & $34 / 100(34 \%)$ \\
\hline $\begin{array}{l}\text { TSCMIX-IPQ015 } \\
\text { D07 }\end{array}$ & $\begin{array}{l}\text { Ataxia-telangiectasia } \\
\text { mutated protein } \\
\text { Sus scrofa }\end{array}$ & 480 & BlastN & $\begin{array}{l}77.8 \\
(39)\end{array}$ & $2 e-11$ & $42 / 43(97 \%)$ \\
\hline $\begin{array}{l}\text { TSCMIX-IPQ015 } \\
\text { E05 }\end{array}$ & $\begin{array}{c}\text { Predicted CDS, tyrosine } \\
\text { specific protein phosphatase } \\
\text { family member (3C803) } \\
\text { C. elegans }\end{array}$ & 360 & BlastX & $\begin{array}{l}55.1 \\
(131)\end{array}$ & $5 e-07$ & $30 / 60(50 \%)$ \\
\hline $\begin{array}{c}\text { TSCMIX-IPQ015 } \\
\text { F12 }\end{array}$ & $\begin{array}{l}\text { similar to ENOD2 } \\
\text { Rattus norvegicus }\end{array}$ & 360 & BlastX & $\begin{array}{c}57.4 \\
(137)\end{array}$ & $9 e-08$ & $31 / 75(41 \%)$ \\
\hline $\begin{array}{l}\text { TSCMIX-IPQ015 } \\
\text { G05 }\end{array}$ & $\begin{array}{l}\text { Proline-rich inner membrane } \\
\text { protein Bordetella } \\
\text { parapertussis - bactéria }\end{array}$ & 360 & BlastX & $\begin{array}{l}52.4 \\
(124)\end{array}$ & $3 e-06$ & $26 / 45(57 \%)$ \\
\hline
\end{tabular}




\begin{tabular}{|c|c|c|c|c|c|c|}
\hline $\begin{array}{c}\text { TSCMIX-IPQ015 } \\
\text { H06 }\end{array}$ & $\begin{array}{c}\text { similar to activated in } \\
\text { Blocked Unfolded protein } \\
\text { response ABU-2, Prion-like } \\
\text { Q/N-rich domain protein } \\
\text { PQN-30, Prion-like Q/N-rich } \\
\text { domain protein (abu-2) } \\
\text { Rattus norvegicus }\end{array}$ & 420 & BlastX & $\begin{array}{c}48.5 \\
(114)\end{array}$ & $4 \mathrm{e}-05$ & $20 / 44(45 \%)$ \\
\hline $\begin{array}{c}\text { TSCMIX-IPQ015 } \\
\text { H08 }\end{array}$ & $\begin{array}{c}\text { smooth muscle myosin light } \\
\text { chain kinase (61-kDa active } \\
\text { fragment) } \\
\text { Gallus gallus }\end{array}$ & 540 & BlastX & $\begin{array}{c}50.4 \\
(119)\end{array}$ & $2 \mathrm{e}-05$ & $30 / 87(34 \%)$ \\
\hline $\begin{array}{c}\text { TSCMIX-IPQ015 } \\
\text { H11 }\end{array}$ & $\begin{array}{c}\text { HECT domain containing 1 } \\
\text { Mus musculus }\end{array}$ & 600 & BlastX & $\begin{array}{c}66.6 \\
(161)\end{array}$ & $3 \mathrm{e}-10$ & $37 / 78(47 \%)$ \\
\hline $\begin{array}{c}\text { TSCMIXb-IPQ016 } \\
\text { B10 }\end{array}$ & $\begin{array}{c}\text { Estrogen receptor beta } \\
\text { Taenia crassiceps }\end{array}$ & 346 & BlastX & $\begin{array}{c}52.0 \\
(123)\end{array}$ & $5 \mathrm{e}-12$ & $22 / 28(78 \%)$ \\
\hline $\begin{array}{c}\text { TSCMIXb-IPQ016 } \\
\text { H03 }\end{array}$ & $\begin{array}{c}\text { CAP, adenylate cyclase- } \\
\text { associated protein 1; } \\
\text { Danio rerio }\end{array}$ & 600 & BlastX & $\begin{array}{c}57.4 \\
(137)\end{array}$ & $2 \mathrm{e}-09$ & $21 / 52(40 \%)$ \\
\hline
\end{tabular}

Sintetizando alguns dos resultados já gerados nesta etapa do trabalho, temos a Tabela 5 .

Tabela 5 - Dados parciais gerados no seqüenciamento de $T$. solium

\begin{tabular}{|l|c|c|}
\cline { 2 - 3 } \multicolumn{1}{c|}{} & $\mathbf{N}^{\circ}$ & \multicolumn{1}{c|}{} \\
\hline $\mathrm{N}^{\circ}$ de ESTs geradas & 2880 & 100 \\
\hline $\mathrm{N}^{\circ}$ de ESTs analisadas até o momento & 864 & 30,00 \\
\hline Seqüências de qualidade satisfatória & 733 & 84,84 \\
\hline Seqüências similares a outros organismos (BLAST) & 90 & 12,28 \\
\hline Seqüências sem similaridade (no match) & 632 & 86,22 \\
\hline Seqüências similares aos genes de T. solium & 5 & 0,68 \\
\hline $\begin{array}{l}\text { Seqüências similares aos genes de outras } \\
\text { espécies de Taenia e helmintos relacionados }\end{array}$ & 6 & 0,82 \\
\hline Novos genes de T. solium & $\begin{array}{c}722 \\
(90+632)\end{array}$ & 98,50 \\
\hline
\end{tabular}




\section{DISCUSSÃO}

\section{Seqüenciamento}

A proposta de seqüenciar um organismo é colocada diante da necessidade de se conhecer a sua composição genética, o que permite e serve como base para que estudos mais aprofundados sejam desenvolvidos. A necessidade de se seqüenciar o genoma completo de um organismo de importância médica, tal como a $T$. solium, tem reflexos óbvios e imediatos com grande potencial de aplicação. No entanto, este é um processo dispendioso e trabalhoso, devido ao grande tamanho de seu genoma, que deve estar próximo ao tamanho do genoma do trematódeo S. mansoni, ou seja, algo ao redor de 300 milhões de nucleotídeos (Simpson et al., 1982) e à grande quantidade de elementos repetitivos que normalmente existem em eucariotos, o que dificulta o processo de bioinformática necessário para a montagem do genoma. Infelizmente, sabemos que a $T$. solium e também as doenças por ela provocadas são absolutamente negligenciadas, apesar de sua grande importância em termos de gravidade, amplitude de distribuição e número de indivíduos contaminados. Com isto, é pouco provável que seu genoma seja seqüenciado em curto prazo.

$\mathrm{Na}$ impossibilidade atual de iniciarmos um projeto que vise seqüenciar o genoma deste parasita, investimos nossos modestos esforços no sentido de contribuir para o maior conhecimento do transcriptoma do parasita, ou seja, do seu conjunto de genes expressos. Para isto, sendo a NCC o nosso principal enfoque de estudo, partimos para explorar o transcriptoma do cisticerco cerebral. A abordagem de seqüenciamento do transcriptoma é amplamente empregada em diversos projetos. Para citar apenas exemplos brasileiros, esta abordagem foi utilizada no Projeto Genoma do Câncer Humano (Dias Neto et al., 2000; Camargo et al., 2001; Brentani et al., 2003), no Projeto transcriptoma do S. mansoni (Verjovski-Almeida et al., 2003), no Projeto SUCEST (Sugar Cane ESTs), no Projeto Genoma funcional do Boi, além do genoma do Café e do Eucalipto (www.fapesp.br).

A abordagem que utilizamos foi a de geração de ORESTES. Tal abordagem foi empregada por uma série de motivos, incluindo: 
* Foi uma técnica desenvolvida por nosso grupo (Dias Neto et al., 2000) e, portanto, prontamente disponível em nosso laboratório;

* A técnica permite a geração de ESTs a partir de quantidades mínimas de mRNA (Dias Neto et al., 1997), situação adequada para o material biológico aqui disponível;

* ORESTES permite analisar a porção mais interna dos transcritos, onde temos a possibilidade de identificar mais facilmente as similaridades das proteínas codificadas;

* ORESTES permite uma avaliação dos transcritos de modo independente de sua abundância, fazendo uma normalização dos genes estudados (Dias Neto et al., 2000);

* A técnica é rápida e barata, e não envolve os complexos passos de construção de uma biblioteca padrão de cDNA.

\section{Aplicabilidade das informações geradas}

As informações referentes aos genes expressos por um organismo têm diversas implicações diretas. O conhecimento dos genes permite identificar vias metabólicas ativas, alvos claros para o desenvolvimento de novos fármacos. Além disto, são evidenciados potenciais alvos antigênicos, que podem gerar antígenos para testes sorológicos ou mesmo para desenvolvimento de vacinas. 0 conhecimento amplo do transcriptoma permite o desenvolvimento de análises em larga escala, que possibilita estudos sobre o posicionamento taxonômico de um organismo e sua evolução em comparação com os demais. Como subproduto de grande interesse para este projeto está a possibilidade de identificar elementos altamente repetitivos (um exemplo clássico são os retrotransposons transcritos) que pode fornecer alvos eficazes para detecção de material genético em testes de diagnóstico molecular.

Uma parte dos clones gerados neste trabalho $(27,78 \%)$ já foi analisada em detalhe. Todas as informações coletadas para estas e para as demais seqüências geradas serão disponibilizadas para a comunidade internacional, em bancos de dados públicos, após a publicação do manuscrito contendo tais informações (manuscrito em preparação). Apesar de nossas análises ainda não terem sido 
concluídas para todas as seqüências geradas, já fomos capazes de identificar uma grande quantidade de genes inéditos para este organismo, além de uma gama de genes com potencial interesse.

\section{Análise nos bancos de dados}

Para a maior parte das nossas análises, usamos o programa BLAST (Basic Local Alignment Sequence Tool) que através de alinhamentos da seqüência analisada contra toda a base de dados selecionada, permite identificar similaridades entre duas seqüências, atribuindo um score de similaridade que, por vezes, pode ser usado para inferir a atividade funcional de uma seqüência. $O$ programa BLAST analisa as seqüências sob duas perspectivas básicas distintas:

3.1 - BlastN: Analisa seqüências nucleotídicas comparando-as com outras seqüências nucleotídicas disponíveis nos bancos de dados. O programa pode ser executado dirigindo as buscas para dois bancos distintos, o banco NR (nãoredundante) e o banco dbEST (banco de dados de ESTs);

3.2 - BlastX: Analisa uma seqüência nucleotídica após fazer a tradução das 6 possíveis molduras de leitura e compara cada uma destas com os bancos de seqüências protéicas disponíveis. Esta análise é de grande valor quando temos uma degeneração da informação nucleotídica, com manutenção da conservação da proteína.

Em nossa primeira análise genética de T. solium (GenBank, 21 de Janeiro de 2003) encontramos a presença de apenas 186 seqüências derivadas deste parasita. Hoje, cerca de dois anos após o início do projeto, existem 245 seqüências nos bancos de dados, mostrando a lenta evolução do conhecimento genômico deste organismo.

Como já dito anteriormente, o GenBank possui dois grandes bancos de dados de seqüências: o banco NR (não redundante), composto por 2.938.105 seqüências e 13.470.522.075 nucleotídeos [GenBank - 15/03/05] e o banco dbEST (banco de dados de Etiquetas de Seqüências Expressas), contém 
26.390.179 seqüências e 13.999.741.637 nucleotídeos [dbEST - 15/03/05]. Cabe notar que o banco dbEST, apesar de ser o maior em termos de números de seqüências e quantidade de nucleotídeos, não possui nenhuma seqüência derivada de espécies do gênero Taenia.

Ao fazermos uma análise mais profunda neste banco de dados, percebemos a grande evolução genética obtida para alguns organismos. Por exemplo, hoje vemos que o organismo mais seqüenciado, em termo de ESTs, é o Homo sapiens, seguido por Mus musculus e Rattus sp, como pode ser visto na Figura 18. Em relação aos organismos de interesse parasitológico, grandes avanços foram feitos com bases nas informações genéticas geradas e depositadas neste mesmo banco de dados. Como mostra a Figura 19, organismos como o S. mansoni, Anopheles gambiae e Toxoplasma gondii, são atualmente os mais estudados. Se por um lado é claro o avanço alcançado no conhecimento dos genes ativos em espécies de grande interesse médico vemos que algumas outras, incluindo-se aqui as espécies de Taenia, são claramente negligenciadas. Esta falta de conhecimento do genoma e do transcriptoma destes organismos impede que aceleremos os esforços de pesquisas do mesmo modo que poderia ser feito com as espécies mais amplamente estudadas. 
Figura 18 - Organismos com maior número de seqüências depositadas no banco dbEST (database of expressed sequence tags).

Fonte: http://www.ncbi.nlm.nih.gov/dbEST/dbEST_summary.html em 24/11/2004.

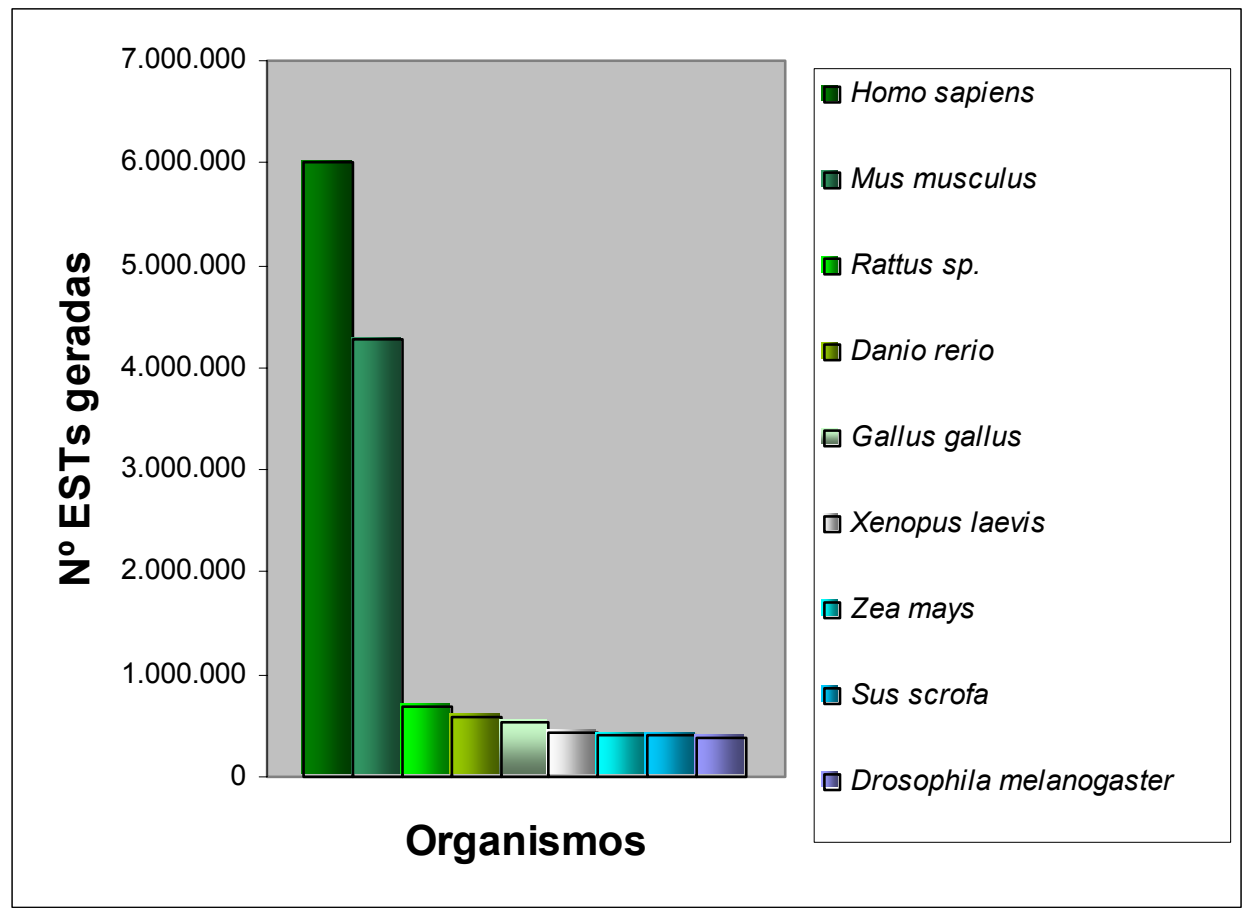

Figura 19 - Organismos de interesse parasitológico com maior número de seqüências depositadas no dbEST.

Fonte: http://www.ncbi.nlm.nih.gov/dbEST/dbEST_summary.html em 24/11/2004.

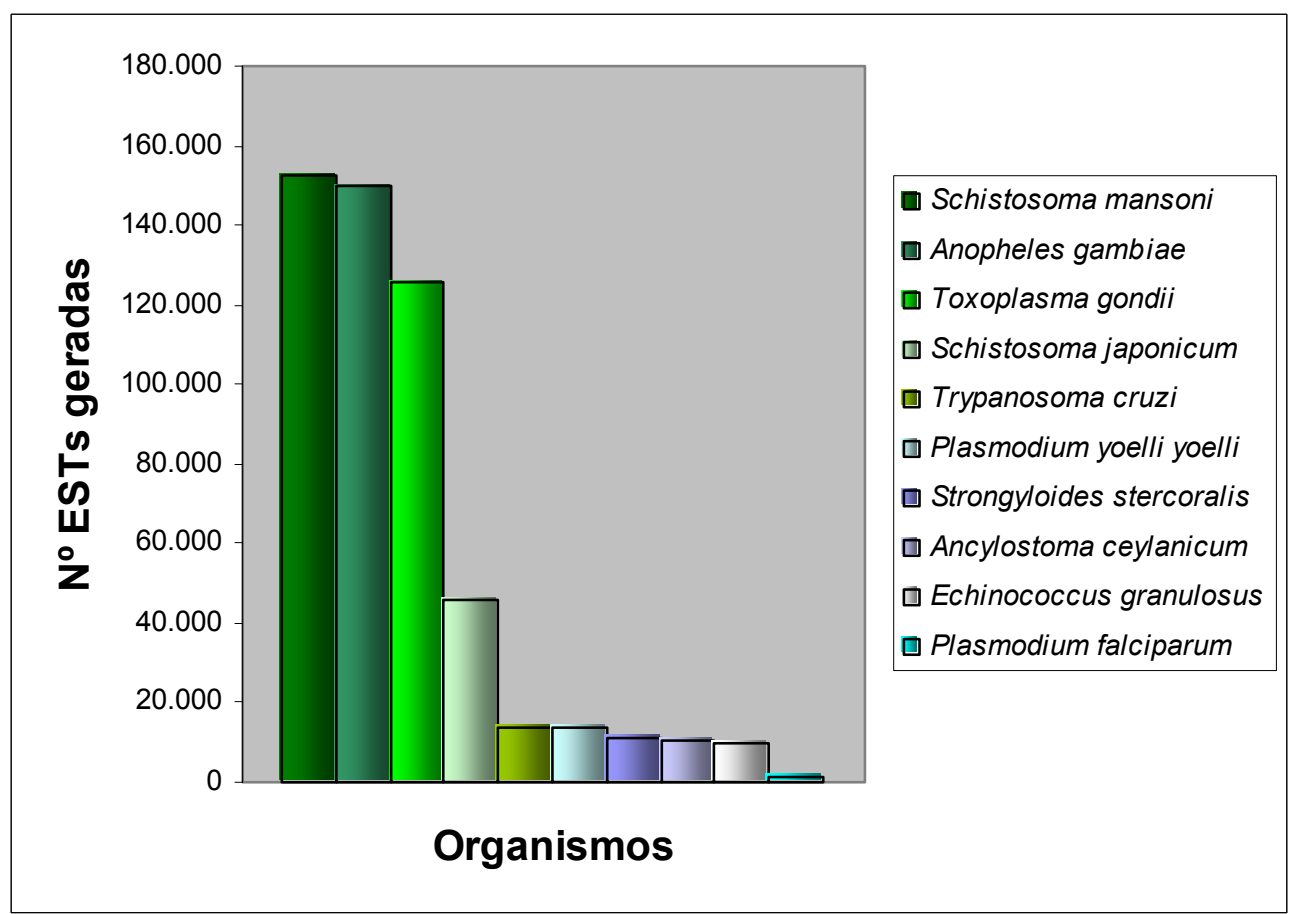




\section{Descoberta gênica em Taenia solium}

Para a geração das seqüências, algumas normas básicas de conduta foram seguidas desde a etapa inicial de coleta dos cisticercos. Estes foram cuidadosamente dissecados de cérebros de suínos, obtidos na região de Pirassununga (Faculdade de Zootecnia e Engenharia de Alimentos da USP), sendo imediatamente congelados em gelo seco para impedir a possível degradação do RNA, o qual precisava estar em boas condições para que as primeiras seqüências de $T$. solium fossem geradas com sucesso.

De modo independente da estratégia escolhida para a construção das bibliotecas de cDNA, a qualidade do mRNA é essencial. Para extrair os RNAs, utilizamos o $\mu$ MACS mRNA Isolation Kit (Miltenyi Biotec - Alemanha), kit que havia sido usado em dois outros projetos de seqüenciamento realizados por nosso grupo (Projeto Genoma do Câncer Humano e Projeto Transcriptoma do S. mansoni).

Após a purificação do mRNA, os cDNAs dupla fita foram sintetizados como descrito, gerando cada um, um perfil de amplificação composto por fragmentos gênicos distintos. Estes foram ligados, clonados, transformados, seqüenciados e analisados. Toda a tecnologia aqui empregada buscou uma maneira mais prática e rápida de identificar alguns dos genes expressos por este parasita. Como mostrado nas tabelas 4 e 5 , as análises feitas no Blast são ricas em informação, revelando uma grande quantidade de novos genes. Dentre as várias informações obtidas, o que nos interessava era encontrar genes que estivessem ligados diretamente a mecanismos fundamentais na manutenção e sobrevivência do cestódeo. Assim, sabendo que a NCC é uma doença caracterizada pela presença do parasita $T$. solium no SNC de organismos superiores (homem, porco), seria interessante aprofundar os estudos em genes que estivessem associados a processos como: imobilização ou diminuição do crescimento do parasita; à produção de ovos ou à fertilidade do verme; a processos inflamatórios, a alterações morfológicas que pudessem ser responsáveis por uma desestabilização da fixação do parasita no hospedeiro, enfraquecendo suas interações e favorecendo sua completa eliminação, e vários outros. No entanto, a imensa maioria dos transcritos encontrados não apresentou similaridade com 
genes ou proteínas já descritos em outros organismos (86,22\%). Esta grande quantidade de transcritos novos, que pode ser o resultado do baixíssimo conhecimento genômico disponível para os cestódeos de maneira geral, dificulta a identificação imediata de alvos de maior interesse. Mesmo assim, fomos capazes de atribuir a possível função de 90 novos genes. Dessa forma, durante as análises destes genes, voltamos nosso foco em genes codificadores de proteínas possivelmente relacionadas a processos tais como os descritos acima, a saber: apoptose (morte celular programada), proteínas de membrana e de adesão celular, proteínas relacionadas ao processo de divisão celular e proteínas com potencial antigênico.

\section{Alguns achados relevantes do transcriptoma de cisticercos de}

\section{T. solium}

Dentre os diversos genes encontrados neste trabalho, selecionamos alguns para serem mais detalhados:

\section{- Calpain (Calpaína)}

Esta proteína foi encontrada durante nossas análises, utilizando o programa BLASTX. Um dos clones obtidos apresentou similaridade com a proteína calpaina descrita em Xenopus laevis, uma espécie de anfíbio já bastante estudada e que possui 449.294 seqüências depositadas no dbEST - (dbEST release 11/03/05). A calpaina é uma proteína que está associada a uma variedade de processos celulares, incluindo apoptose, divisão celular, modulação das interações do citoesqueleto e plasticidade sináptica. A seqüência analisada possui 300 nucleotídeos, sendo que os aminoácidos por eles determinados, da posição 283 a 149, encontraram uma similaridade significativa (86\%) com uma calpaina previamente descrita em $X$. laevis. A Figura 21 representa a seqüência obtida e a similaridade observada com o anfíbio. 
Figura 21- Análise da proteína calpaina encontrada utilizando o programa BLASTX (release 19/10/04):

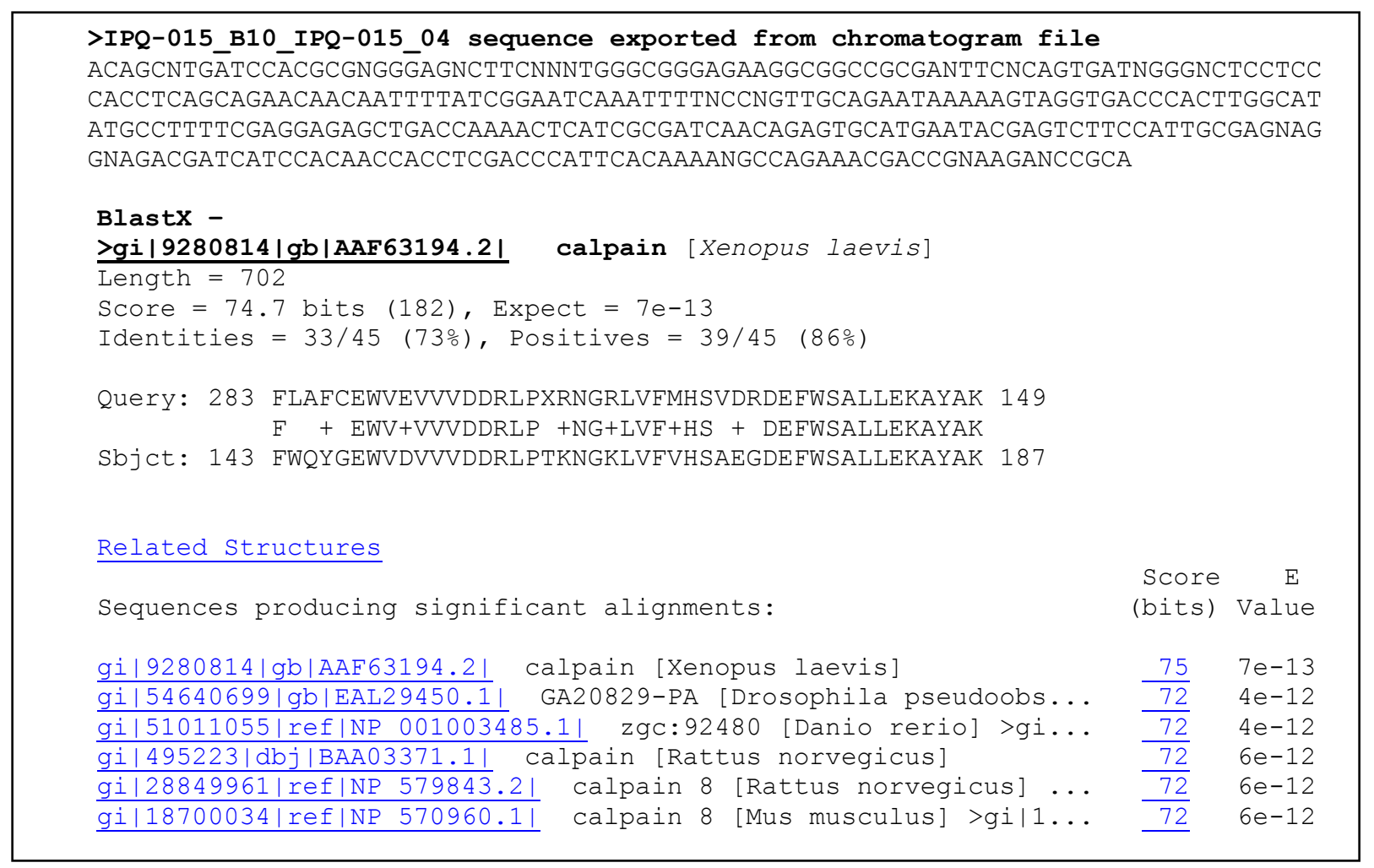

\section{- Myosin Heavy Chain (Cadeia Pesada de Miosina)}

Um outro novo gene de $T$. solium aqui identificado (CLONE Tsc008IPQ013_H06) possivelmente corresponde ao gene codificador da proteína myosin heavy chain, descrito no parasita S. mansoni. A similaridade observada foi de 93\%, com uma identidade de 83\% em um trecho de 131 aminoácidos. Cabe notar que o S. mansoni é um trematódeo, classe próxima à dos cestódeos, onde se localiza o gênero Taenia. Esta proteína é bastante conhecida e está associada ao processo de contração muscular. Sua propriedade é bastante interessante, pois conhecendo bem os processos de contração muscular do parasita é possível causar desarranjos em tal mecanismo e impedir a fixação do verme no hospedeiro. Além disto, uma droga que vise especificamente a miosina do parasita poderia atuar impedindo a migração dos cisticercos. A Figura 22 mostra os resultados de análise desta seqüência. 
Figura 22 - Análise da proteína myosin heavy chain encontrada utilizando o programa BLASTX (release 19/10/04):

\begin{abstract}
>TSC008-IPQ013_H06_TSC008-IPQ sequence exported from chromatogram file
NAGCTATGCATCCĀACGCGTTGGGAGCTCTCCCATATGGTCGACCTGCAGGCGGCCGCGAATTCACTAGTGATTTGTC TTTCCCTGCTGCTCTTCACGCGGACGCTGCTTGAATTTCATCTCACCCATATTGATGACGGAGGTGGTGCATTTAAAC ATCGACATCCTCTCGTCGTTGGAGAAACCGAGGATGTCAATAGCCTCATCAGTGATCTTCATCTCCTCCGCATCGTCT ACACCGTCGATGGTAAGTTCACCTTGATTGATGAAGGAGTAGAGGGCCGGATCGGCTGAGACCAGAAGCTTGTCGTGA TATTTCTTGCCGTAGTCGGAGAGTATTTGGTAGAAAATGTGGAAGTTACGCTCTCCCTTCATTTGTGAGGTGACACGA GACTTCTCCAGCAGATAGAACTCAATGTCAGCTCCGGCAATTTTTCCCGTCGTGCCGAAATGGATACGAATGAATTTG CCGAATCGGGAGCAGCAGGGAAAGAAAATCGAATTCCCGCGGCCGCCATGGGGCGGGAACATGCNACGNCGGGCCNAT TCGCCTAAGGGAGCGAATANATTCATGGCCGCGTT
\end{abstract}

BlastX-

>gi|11276951|pir||A59287 myosin heavy chain - fluke (Schistosoma mansoni) (strain Brazilian LE)

gi|161044|gb|AAA29905.1| myosin heavy chain

Length $=1940$

Score $=234$ bits $(597)$, Expect $=8 e-61$

Identities $=110 / 131(83 \%)$, Positives $=122 / 131$ (93\%)

Query: 479 SRFGKFIRIHFGTTGKIAGADIEFYLLEKSRVTSQMKGERNFHIFYQILSDYGKKYHDKL 300 SRFGKFIRIHFGTTGKIAGADIE YLLEKSRV SQMKGERN+HIFYQ+LS YG KYHDKL

Sbjct: 235 SRFGKFIRIHFGTTGKIAGADIEHYLLEKSRVVSQMKGERNYHIFYQLLSTYGSKYHDKL 294

Query: 299 LVSADPALYSFINQGELTIDGVDDAEEMKITDEAIDILGFSNDERMSMFKCTTSVINMGE 120 LV DPALYSFINQGELTIDGVDD+EEMK+ DEA ++LGF++DE++S+FKCTTS+ NMGE

Sbjct: 295 LVQTDPALYSFINQGELTIDGVDDSEEMKLCDEAFEVLGFNDDEKLSLFKCTTSICNMGE 354

Query: 119 MKFKQRPREEQ 87 MKFKQRPREEQ

Sbjet: 355 MKFKQRPREEQ 365

Related Structures

Sequences producing significant alignments: (bits) Value

gi|11276951|pir||A59287 myosin heavy chain - fluke (Schisto... 234 1e-60 gi|3986194|dbj|BAA34954.1| myosin heavy chain [Dugesia japo... 233 2e-60

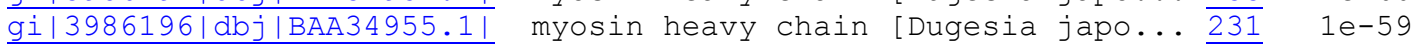

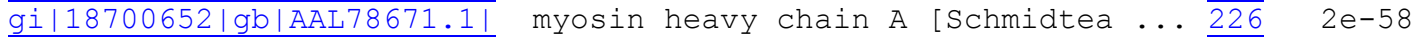
gi|4249742|gb|AAD13782.1| myosin II heavy chain [Ilyanassa ... $\frac{198}{6 e-50}$

\title{
- Heat Shock Protein 90 (Proteína Heat Shock)
}

Um gene potencialmente interessante que identificamos corresponde à proteína de choque térmico 90 (HSP90), descrita no nematódeo Caenorhabiditis elegans. Em C. elegans, esta proteína, também conhecida como DAF-21 ou Tax3 , é preferencialmente expressa em células germinativas e parece ser um importante quimio e termosensor, que parece atuar na migração do verme 
direcionando-o em sua locomoção e busca de alimento (Inoue et al., 2003). Se a função da proteína em $T$. solium for conservada, a identificação deste gene e sua posterior inativação por droga pode ser um alvo de grande interesse.

Figura 23 - Análise da proteína heat shock protein 90 encontrada pelo programa tBLASTX (release 19/10/04):

\begin{abstract}
>TSC007IPQ012_B01_.B_03 sequence exported from chromatogram file
ACAGCTATGCATCCAACGCGTTGGGAGCTCTCTTNTCTGGTCGAAGGGAAGGCGGCCGCGAATTCNTNCNTGATTTTC СTCTCCTCCCACCTCATGGAGCGGATTATGAAGGCTCAAGCACTTCGCGANTCCNNNACGATGGGGTACATGTCCGCC AAAAAGCATCTGGAGATCAATCCCGATCACAAAGTTATGATCCGCCTAAAGGAAATGTTATCGGCTGAAGGTGAACCG AACAAGATTTGCAAGGATCTAATAAACGTGCTTTTCAGCACAGCCCTGCTCGCTTCGGGATTCACTTTGGAGGATCCG AAGGCTCATGCCAATAAAATCCACGAGCTGATAAGCATGTGTTTGGAGGTGGGAGGAGAGGAAAATCGAATTCCCGCG GCCGCCATGGCGGCGGGGAGCATGCGACGNCGGNCCCAATTCGCCCTATAGGGAGGCGNATNACAATTCACTGGCCGN CGTTTANA
\end{abstract}

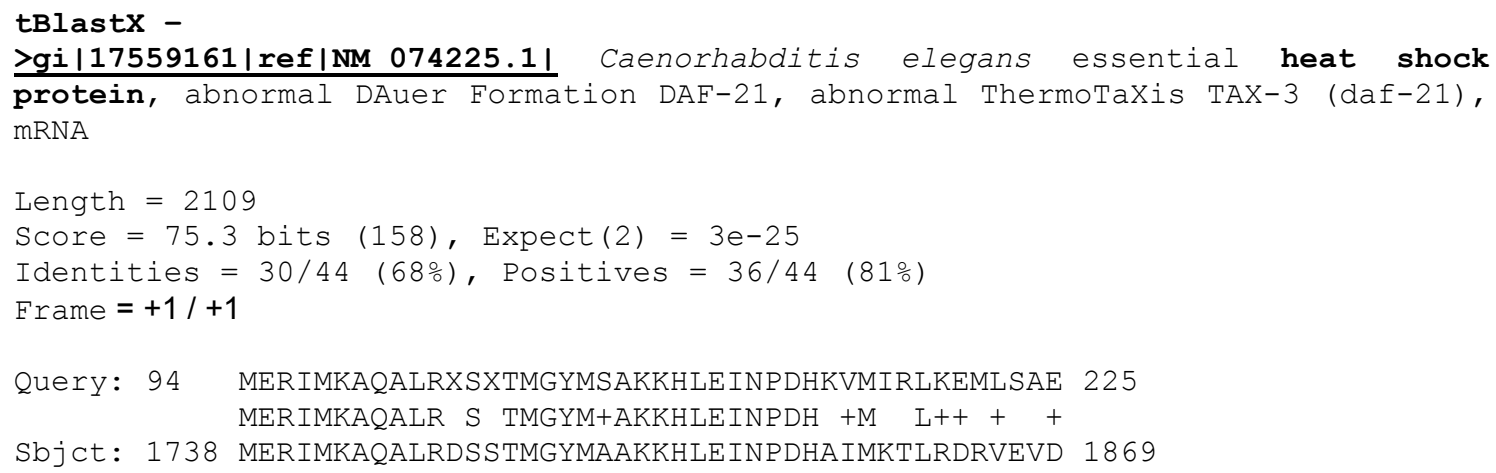

Como representado acima, vimos a similaridade entre os aminoácidos presentes em ambas as espécies comparadas, dando-nos condições para inferir a função de mais uma nova proteína de $T$. solium. 


\section{- Desmoyokin (Desmoioquina)}

A desmoioquina é uma proteína presente na membrana celular, cuja função é, entre outras, promover a adesão celular. Esta proteína, também envolvida com a exocitose, pode ter uma grande importância nos processos de formação dos tecidos do parasita, além de estar, provavelmente, relacionada aos processos de reconhecimento do sistema imunológico do hospedeiro, bem como no controle do metabolismo e na divisão celular do parasita. Estas duas características são de extrema importância para os processos de manutenção do parasita dentro do hospedeiro, e estudos direcionados a este tipo de proteína podem ser eficazes em medidas promissoras de combate à doença.

Cabe ainda notar que Skoldberg et al. (2002) demonstraram que esta proteína foi identificada como um importante auto-antígeno no Lupus eritematoso sistêmico, o que demonstra suas propriedades antigênicas. A Figura 24 traz a análise destas seqüências. Podemos notar que a similaridade com a proteína de camundongo é suficientemente alta para sugerir a sua identificação em $T$. solium, mas baixa o suficiente para garantir que a mesma não se trata de um contaminante.

Figura 24 - Análise da proteína desmoyokin encontrada em análises do BLASTX (release 19/10/04):

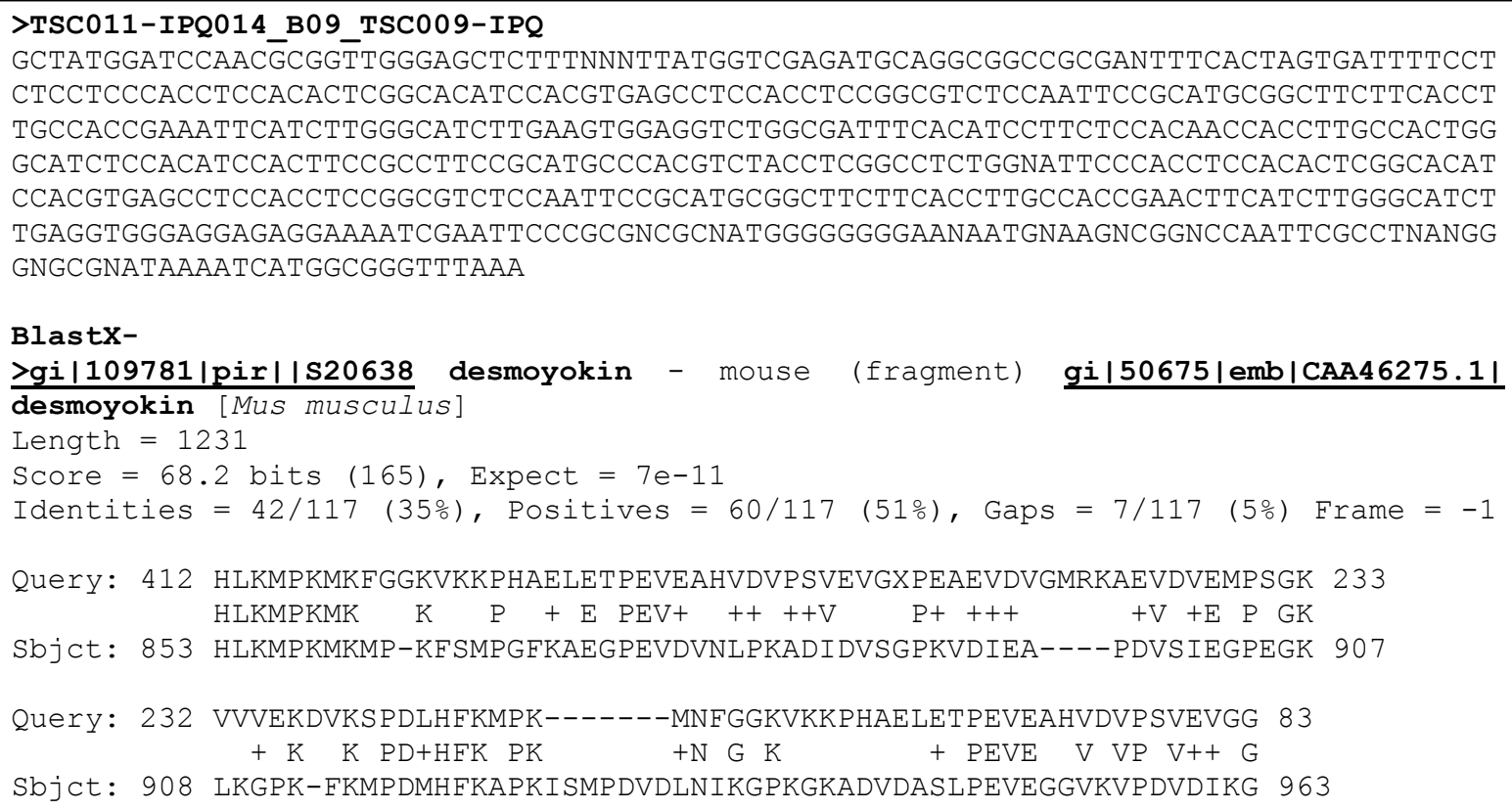
СTCCTCCCACCTCCACACTCGGCACATCCACGTGAGCCTCCACCTCCGGCGTCTCCAATTCCGCATGCGGCTTCTTCACCT TGCCACCGAAATTCATCTTGGGCATCTTGAAGTGGAGGTCTGGCGATTTCACATCCTTCTCCACAACCACCTTGCCACTGG GCATCTCCACATCCACTTCCGCCTTCCGCATGCCCACGTCTACCTCGGCCTCTGGNATTCCCACCTCCACACTCGGCACAT CCACGTGAGCCTCCACCTCCGGCGTCTCCAATTCCGCATGCGGCTTCTTCACCTTGCCACCGAACTTCATCTTGGGCATCT TGAGGTGGGAGGAGAGGAAAATCGAATTCCCGCGNCGCNATGGGGGGGGAANAATGNAAGNCGGNCCAATTCGCCTNANGG GNGCGNATAAAATCATGGCGGGTTTAAA

BlastX-

>gi|109781|pir||S20638 desmoyokin - mouse (fragment) gi|50675|emb|CAA46275.1| desmoyokin [Mus musculus] 
Related Structure

Sequences producing significant alignments:

Score $E$

(bits) Value

gi|37675525|gb|AAQ97238.1| AHNAK [Mus musculus]

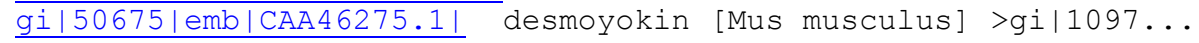

gi|34849580|gb|AAH58223.1| Lor protein [Mus musculus] >gi|4...

gi|6678708|ref|NP 032534.1| loricrin [Mus musculus] >gi|110...

gi|55641497|ref|XP 510203.1| PREDICTED: similar to KIAA2019...

\begin{tabular}{ll}
$\frac{68}{68}$ & $9 e-11$ \\
\hline$\frac{66}{66}$ & $4 e-11$ \\
\hline 65 & $4 e-10$ \\
$6 e-10$
\end{tabular}

Além destes genes mostrados como exemplo, encontramos ainda outros de igual importância, a saber: outer membrane lipoprotein sorting protein, uma proteína de membrana que pode estar envolvida com a produção de endotoxinas e desempenhar função protetora; cell wall surface anchor family protein, uma proteína de membrana que tem função protetora; connectin $3 B$, uma proteína muscular associada à fixação do parasita; entre outros. Devemos notar o bom potencial antigênico destas últimas proteínas por sua localização na membrana celular. Este potencial pode ser explorado no contexto do desenvolvimento de vacinas ou de antígenos a serem usados em imunodiagnóstico.

Esta análise foi replicada para cada uma das 864 ESTs analisadas até o momento, sendo que todos estes dados gerados estarão disponíveis em bancos de dados públicos. As análises globais de todas as ESTs seqüenciadas serão feitas com o auxílio do grupo de bioinformática coordenado pelo Dr. Paulo S. L. Oliveira, do InCor HCFMUSP. Todas as seqüências serão depositadas em bancos de dados públicos (dbEST), visando estimular o avanço da pesquisa nesta área. 


\section{CONCLUSÃO}

Os resultados apresentados na segunda parte deste trabalho podem ser resumidos nos seguintes ítens:

- Geramos as primeiras ESTs de T. solium, num total de 2880, superando em quase 3 vezes a meta inicial de 1000 ESTs. Deste modo, aumentamos em 11 vezes o número de seqüências conhecidas para este parasita;

- Nas primeiras análises, encontramos genes de interesse que podem codificar proteínas a serem usadas como alvo para imunodiagnóstico, imunoterapia ou como alvo de novas drogas;

- A grande maioria das seqüências geradas neste trabalho $(74,42 \%)$ são inéditas, o que representa um significativo enriquecimento das informações disponíveis à respeito da biologia deste parasita de grande importância médica;

- Com o intuito de subsidiar a pesquisa nesta área, todas as seqüências aqui geradas serão depositadas em bancos de dados públicos assim que o trabalho for submetido à publicação em revista especializada. 


\section{REFERÊNCIAS BIBLIOGRÁFICAS}

Allan, J.C., Avila, G., Garcia Noval, J., Flisser, A., Craig P.S. Immunodiagnosis of taeniasis by coproantigen detection. Parasitology 1990, 101: 473-77.

Alvarez R.E., Torres-Garate R, Gutierrez Larrainzar A, Cabello J, Espinos Perez D. Neurocysticercosis: report of three cases and recommendations of treatment. Am Med Interna. 2004 Aug; 21(8):382-6.

Arseni, C. \& Cristescu, A. Epilepsy due to cerebral cysticercosis. Epilepsia 1972, 13: 253-58.

Barry, M. \& Kaldjian, L.C. Neurocysticercosis. Sem Neurol 1993, 13: 131-43.

Brentani H., Otávia A., Caballero L., et al. The generation and utilization of a cancer-oriented representation of the human transcriptome by using expressed sequence tags. Proc Natl Acad Sci USA. 2003; 100(23): 13418-13423.

Bueno E.C., Vaz A.J., Machado L., Livramento J.A. Total IgE detection in paired cerebrospinal fluid and serum samples from patients with neurocysticercosis. Rev Inst Med Trop São Paulo. 2000; 42(2): 67-70.

Camargo A.A., Samaia H.P., Dias-Neto E., et al. The contribution of 700,000 ORF sequence tags to the definition of the human transcriptome. Proc Natl Acad Sci USA. 2001;98(21):11837-8.

Cantú, C. \& Barinagarrementeria, F. Cerebrovascular complications of neurocysticercosis clinical and neuroimaging spectrum. Arch. Neurol 1996, 53: 233-39.

Carpio, A. Neurocysticercos: an update. The Lancet Infectious Disease 2002 (2). 
CDC, Centers for Disease Control: Update: Internacional task force for disease eradication. MMWR 1992, 41(691): 697-698.

Chapman, A., Vallejo V., Mossie K.G., Ortiz D., Agabian N., Flisser A. Isolation and characterization of Species-Specific DNA Probes from Taenia solium and Taenia saginata and their use in an egg detection assay. J Clin. Microbiol 1995, 33(5): 1283-1288.

Del Brutto, O.H. \& Noboa, C.A. Late-onset epilepsy in Ecuador: an etiology and clinical features in 225 patients. J Trop Geogr Neurol 1991, 1:31-34.

Del Brutto, O.H. \& Sotelo, J. Neurocysticercosis: an update. Rev. Infect Dis 1988, 10: $1075-87$.

Del Brutto, O.H. CT findings in neurologicaly normal adults with a single generalized seizure. J Epilepsy 1994, 7: 38-40.

Del Brutto, O.H. Cysticercosis. In: Feldmann, E, ed. Current diagnosis in neurology. St. Louis: Mosby, 1994: 125-29.

Del Brutto, O.H. Medical management of neurocysticercosis. Int J Ant Ag 1993, 3: 133-37.

Del Brutto, O.H., Castillo, P.R., Mena, I.X., Freire, A.X. Neurocysticercosis among patients with cerebral gliomas. Arch Neurol 1997, 54: 1125.

Del Brutto, O.H., Santibañez, R., Noboa, C.A., Aguirre, R., Díaz, E., Alarcón, T.A. Epilepsy due to neurocysticercosis: analysis of 203 patients. Neurology 1992, 42: 389-92.

Dias Neto E, Garcia Correa R, Verjovski-Almeida S, Briones MR, Nagai MA, da Silva W Jr, Zago MA, Bordin S, Costa FF, Goldman GH, Carvalho AF, Matsukuma 
A, Baia GS, Simpson DH, Brunstein A, de Oliveira PS, Bucher P, Jongeneel CV, O'Hare MJ, Soares F, Brentani RR, Reis LF, de Souza SJ, Simpson AJ. Shotgun sequencing of the human transcriptome with ORF expressed sequence tags. Proc Natl Acad Sci USA 2000, 28; 97(7):3491-6

Dias Neto E., Harrop R., Correa Oliveira R., et al. Minilibraries constructed from cDNA generated by arbitrarily primed RT-PCR: an alternative to normalized libraries for the efficient generation of ESTs from nanogram quantities of mRNA. Gene, v. 186, p. 135-142, 1997.

Fleury, A., Dessein, A., Preux, P.M., Dumas, M., Tapia, G., Larralde, C., Sciutto, E. Symptomatic human neurocysticercosis: age, Sex and exposure factors relating with disease heterogeneity. J. Neurol 2004, 251: 830-37.

Fleury, A., Gomes, T., Alvarez, I., Meza, D., Huerta, M., Chavarria, A., Carrillo Mezo, R.A., Lloyd, C., Dessein, A., Preux, P.M., Dumas, M., Larralde, C., Sciutto, E., Fragoso, G. Silent neurocysticercosis in a rural village of Mexico: High prevalence of calcified lesions in a CT scan based epidemiological survey and its relation with exposure and host factors. Neuroepidemiology 2003, 22: 139-45.

Garcia, H.H. \& Del Brutto, O.H. Emerging and re-emerging diseases in Latin America. Taenia solium cysticercosis. In: Infectious Disease Clinics of North America 2000, 14 (1).

Garcia, H.H. \& Del Brutto, O.H. Taenia solium cysticercosis. Infect Dis Clin North America 2000, 14: 97-119.

Garcia, H.H., Gilman, R.H., Tovar, M.A., et al. Factors associated with Taenia solium cysticercosis: analysis of nine hundred forty-six Peruvian neurologic patients. Am J Trop Med Hyg 1995, 52:145-48. 
Garcia, H.H., Gonzalez, A.E., Evans, C.A.W., Gilman, R.H. Taenia solium cysticercosis. The Lancet 2003, 362: 547-56.

Garcia, H.H., Gonzalez, A.E., Gilman, R.H. Diagnosis treatment and control of Taenia solium cysticercosis. Current Opinion in Infectious Disease 2003, 16: 41119.

Gonzalez A.E., Verastegui M., Noh J.C., Gavidia C., Falcon N., Bernal T., Garcia H.H., Tsang V.C., Gilman R.H., Wilkins P.P. Persistence of passively transferred antibodies in porcine Taenia solium cysticercosis. Cysticercosis Working Group in Peru. Vet Parasitol. 1999; 86(2):113-8.

González, L.M., Montero, E., Harrison, L.J.S., Parkhouse, R.M.E., Garate, T. Differential Diagnosis of Taenia saginata and Taenia solium Infection by PCR. Journal of Clinical Microbiology 2000, 38(2): 737-44.

González, L.M., Montero, E., Puente, S., López-Velez, R., Hernández, M., Sciutto, E., Harrison, L.J.S., Parkhouse, R.M.E., Garate, T. PCR tools for the differential diagnosis of Taenia saginata and Taenia solium taeniasis/cysticercosis from different geographical locations. Diagnostic Microbiology and Infectious Disease 2002, 42: 243-49.

Guo, Y., Sun, S., Zhang, Y., Chen, Z., Wang, K., Huang, L., Zhang, S., Zhang, H., Wang, Q., Wu, D., Zhu, W. Protection of pigs against Taenia solium cysticercosis using recombinant antigen or in combination with DNA vaccine 2004, 22: 3841-47.

Herrera, L.A., Ramirez, T., Rodríguez, U., Corona, T., Sotelo, J., Lorenzo, M., Ramos, F., Verdorfer, I., Gebhart, E., Ostrosky-Wegman, P. Possible association between Taenia solium cysticercosis and cancer: increase frequency of DNA damage in peripheral lymphocytes from neurocysticercosis patients. Transactions of the Royal society of Tropical Medicine and Hygiene 2000, 94: 61-65. 
Huerta, M., Aluja, A., Fragoso, G. Toledo, A., Villalobos, N., Hernández, M., Gevorkian, G., Acero, G., Díaz, A., Alvarez, I., Avila, R., Béltran, C., García, G., Martínez, J.J., Larralde, C., Sciutto, E. Synthetic peptide vaccine against Taenia solium pig cysticercosis: successful vaccination in a controlled field trial in rural Mexico. Vaccine 2001, 2793: 1-5.

Husain, N., Jyotsna, M.B., Husain, M., Mishra, M.K., Gupta, S. Evaluation of Cysticercus Fasciolaris Antigen for the Immunodiagnosis of Neurocysticercosis. Neurol India 2001; 49: 375-379.

Inoue T., Takamura K., Yamae H., Ise N., Kawakami M., Tabuse Y., Miwa J., Yamaguchi Y. Caenorhabditis elegans DAF-21 (HSP90) is characteristically and predominantly expressed in germline cells: spatial and temporal analysis. Dev Growth Differ. 2003; 45(4):369-76.

International Laegue Against Epilepsy: Relationship between epilepsy and tropical diseases. Epilepsia 1994, 35, 89-93.

Ito, A. \& Craig, P.S. Immunodiagnostic and molecular approaches for the detection of taeniid cestode infections. TRENDS in Parasitology 2003, 19(9): 377-81.

Ito, A., Nakao, M., Wandra, T. Human taeniasis and cysticercosis in Asia. The Lancet (362); 2003.

Ito, A., Yamasaki, H., Nakao, M., Sako, Y., Okamoto, M., Sato, M.O., Nakaya, K., Margono, S.S., Ikejima, T., Kassuku, A.A., Afonso, S.M.S., Ortiz, W.B., Plancarte, A., Zoli, A., Geerts, S., Craig, P.S. Multiple genotypes of Taenia solium ramifications for diagnosis, treatment and control. Acta Trop 2003, 87: 95-101.

Jamison, S., Hernandez, O., Natividad, T., Smith, T., Mclnnis, J. Medical Student Morning Report Presentation. www.utmb.edu/pedi/Residency/Neurocyst.ppt 
Junqueira, L.C. \& Carneiro, J. Biologia Celular e Molecular. $7^{a}$ Edição - Ed. Guanabara Koogan

Lawrence, D. Active neurocysticercosis brain lesions predict risk of future seizures. The Lancet 2002, 360: 1947.

Lightowlers, M.W. \& Gauci, C.G. Vaccines against cysticercosis and hydatidoses. Vet. Parasitol 2001, 101: 337-352.

López-Hernández, A. \& Garaizar, C. Childhood cerebral cysticercosis: clinical features and computed tomographic findings in 89 Mexican children. Can J Neurol Sci 1982, 9: 401-07.

Machnicka, B., E. Dziemian, and C. Zwiers. Detection of Taenia saginata antigens in faeces by ELISA. Appl. Parasitol 1996, 37:106-110.

Machnicka, B., E. Dziemian, and C. Zwiers. Factors conditioning detection of Taenia saginata antigens in faeces. Appl. Parasitol 1996, 37:99-105.

Medina, M.T \& Christopher, M.D. In: Introduction to neurocysticercosis: a worldwide epidemic. J Neurosurg (12); 2002.

Nakao, M., Okamoto, M., Sako, Y., Yamasaki, H., Nakaya, K., Ito, A. A phylogenetic hypothesis for the distribution of two genotypes of the pig tapeworm Taenia solium worldwide. Parasitology 2002, 124: 657-662.

Neves D.P. Parasitologia Humana, 10a. Edição, Editora Atheneu, 2000.

Nunes, C.M., Lima, L.G.F., Manoel, C.S., Pereira, R.N., Nakano, M.M., Garcia, J.F. Taenia saginata: polymerase chain reaction for taeniasis diagnosis in human fecal samples. Experimental Parasitology 2003, 104: 67-69. 
Pal, D.K., Carpio, A., Sander, J.W.A.S. Neurocysticercosis and epilepsy in developing countries. J Neurol Neurosourg Pshychiatry 2000, 68: 137-143.

Pardini, A.X., Peralta, R.H., Vaz, A.J., Machado, L.R., Peralta, J.M. Use of Taenia crassiceps cysticercus antigen preparations for detection of antibodies in cerebrospinal fluid samples from patients with neurocysticercosis (Taenia solium). Clin Diagn Lab Immunol 2002, 9 (1): 190-193.

Pardini, A.X., Vaz, A.J., Machado, L.R., Livramento, J.A. Cysticercus Antigens in Cerebrospinal Fluid Samples from Patients with Neurocysticercosis. Journal of Clinical Microbiology 2001, 39(9): 3368-72.

Plancarte, A., Flisser, A., Gauci, C.G., Lightowlers, M.W. Vaccination against Taenia solium cysticercosis in pigs using native and recombinant oncosphere antigens. Int. J. Parasitol 1999, 29: 1965-1970.

Pontes, L.A., Neto, E.D., Rabello, A. Detection by polymerase chain reaction of Schistosoma mansoni DNA in human serum and feces. Am J Trop Med Hyg. 66(2), 2002, pp. 157-162.

Quintana, M.I, Solano, J., Rodriguez, K Neurocysticercosis auxiliary diagnosis using Genetic Algorithms and Western Blot Images. Medical Image Understanding and Analysis 2001, 125-128.

Sanchez, A.L., Lindbäck, J., Schantz, P.M., Sone, M., Sakai, H., Medina, M.T., Ljungström, I. A population-based, case-control study of Taenia solium taeniasis and cysticercosis. Ann Trop med Parasitol 1999, 93: 247-258.

Sanchez, A.L., Ljungström, I., Medina, M.T. Diagnosis of human neurocysticercosis in endemic countries: a clinical study in Honduras. Parasitol. Int 1999, 48: 81-89. 
Sanguinetti, C.J., Dias Neto, E. Simpson, A.J. Rapid silver staining and recovery of PCR products separated on polyacrylamide gels. Biotechniques 1994, 17(5): 914-21.

Sciutto, E., Aluja, A., Fragoso, G., Rodarte, L.F., Hérnandez-Gonzales, M., Villalobos, M.N., Padila, A., Keilbach, N., Baca, M., Govezensky, T., Díaz, S., Larralde, C. Immunization of pigs against Taenia solium cysticercosis: factors related to effective protection. Vet Parasitol 1995, 60: 53-67.

Sciutto, E., Fragoso, G., Manoutcharian, K., Gevorkian, G., Rosas-Salgado, G., Hérnandez-Gonzales, M., Herrera-Estrella, L., Cabrera-Ponce, J.L., LópezCasillas, F., González-Bonilla, C., Santiago-Machuca, A., Ruíz-Peres, F., Sánchez, J., Goldbaum, F., Aluja, A., Larralde, C. New Approaches to Improve a Peptide Vaccine Against Porcine Taenia solium Cysticercosis. Archives of Medical Research 2002, 33: 371-78.

SES-SC: Secretaria de Estado da Saúde do Estado de Santa Catarina. Levantamento de dados sobre cisticercose em Santa Catarina de 1990 a 1995.

Simpson A.J., Sher A., McCutchan T.F. The genome of Schistosoma mansoni: isolation of DNA, its size, bases and repetitive sequences. Mol Biochem Parasitol. 1982; 6(2):125-37.

Skoldberg F., Ronnblom L., Thornemo M., Lindahl A., Bird P.I., Rorsman F., Kampe O., Landgren E. Identification of AHNAK as a novel autoantigen in systemic lupus erythematosus. Biochem Biophys Res Commun. 2002 Mar 8; 291(4):951-8.

Song, E.K., Kim, I.H., Lee, S.O. Unusual manifestations of Taenia solium infestation. Journal of Gastroenterology 2004, 39(3): 288-291. 
Sotelo, J., Torres, B., Rubio-Donadieu, F., Escobedo, F., Rodriguez-Carbajal, J. Praziquantel in the treatment of neurocysticercosis: a long-term follow-up. Neurology 1985; 35: 752-755.

Takayanagui, O.M. \& Jardim, E. Therapy for neurocysticercosis: comparison between albendazole and praziquantel. Arch Neurol 1992, 49: 290-294.

Tsang, V.C.W. \& Wilson, M. Taenia solium cysticercosis: An under recognized but serious public health problem. Parasitol. Today 1995, 11: 124-126.

Verjovski-Almeida S., DeMarco R., Martins E.A.L., Guimarães P.E.M., Ojopi E.P.B., et al. Transcriptome analysis of the acoelomate human parasite Schistosoma mansoni. Nature Genetics 35(2): 148-157, 2003.

Yamasaki H., Allan J.C., Sato M.O., Nakao M., Sako Y., Nakaya K., Qiu D., Mamuti W., Craig P.S., Ito A. DNA differential diagnosis of taeniasis and cysticercosis by multiplex PCR. J Clin Microbiol. 2004; 42(2):548-53.

Yang S. \& Rothman R.E. PCR-based diagnostics for infectious diseases: uses, limitations, and future applications in acute-care settings. Lancet Infect Dis. 2004; 4(6):337-48.

World Health Organization. Fifty-Fifth World Health Assembly. Provisional agenda item 13.18, 2002.

$\underline{\text { www.fapesp.br }}$ 


\title{
VIII. ANEXO I
}

\section{TAENIA SOLIUM DNA IS PRESENT IN THE CEREBROSPINAL FLUID OF NEUROCYSTICERCOSIS PATIENTS}

\author{
Running title - Taenia DNA at CSF in neurocysticercosis
}

Carolina R. Almeida ${ }^{1}$, Elida P. Ojopi ${ }^{1}$, Cáris M. Nunes ${ }^{2}$, Luis R. Machado $^{3}$, Osvaldo M. Takayanagui ${ }^{4}$, José A. Livramento ${ }^{3}$, Ronaldo Abraham $^{5}$, Wagner F. Gattaz ${ }^{1}$, Adelaide J. Vaz ${ }^{6}$ \& Emmanuel Dias-Neto ${ }^{1 *}$

1 - Laboratório de Neurociências (LIM-27), Instituto e Departamento de Psiquiatria, Faculdade de Medicina, Universidade de São Paulo (FMUSP). R. Dr. Ovídio Pires de Campos, s/n- $3^{\circ}$ andar. 05403-010, São Paulo, SP, Brazil.

2 - Depto de Apoio, Produção e Saúde Animal. UNESP-Araçatuba. Rua Clóvis Pestana, 793. 16050-680, Araçatuba,SP, Brazil.

3 - Depto de Neurologia, FMUSP, Universidade de São Paulo (FMUSP). 05403-010, São Paulo, SP, Brazil.

4 - Depto de Neurologia, Faculdade de Medicina de Ribeirão Preto, Universidade de São Paulo, 14048-900 Ribeirão Preto, SP, Brazil.

5 - Depto de Medicina, Universidade de Taubaté, Taubaté, SP, Brazil.

6 - Laboratório de Imunologia Clínica, Faculdade de Ciências Farmacêuticas, Universidade de São Paulo. Av. Prof. Lineu Prestes, 580 bloco 17. 05508-900, São Paulo, SP, Brazil.

\section{* - Corresponding author}


SUMMARY - Neurocysticercosis is the most frequent parasitic infection of the CNS. We demonstrate here that Taenia solium DNA is present in the cerebrospinal fluid of patients enabling the correct identification of 29/30 cases $(96.7 \%)$. The presence of parasite DNA in the CSF may be a strong support for the diagnosis of neurocysticercosis.

Keywords - PCR, CSF, neurocysticercosis, Taenia solium, cerebrospinal fluid. 
Neurocysticercosis (NC), the most common parasitic infection of the central nervous system, is globally spreading due to the increase of the migration, immigration, tourism and globalization (Earnest et al., 1987; Wallin et al., 2004). It is estimated that globally, 50 million people are infected with the taeniasis/cysticercosis complex and 50,000 die from cysticercosis annually (CDC, 1993), whereas a much higher number present other types of neurological damages (Ito et al., 2003).

Considering the high specificity and sensitivity usually attained by DNAbased diagnostic tests, we evaluated the presence of cysticercus-DNA in the cerebrospinal fluid (CSF) of patients. This new approach may provide additional support to define diagnosis, since imaging procedures are costly and have scarce availability in areas where the most of the affected population is located.

Taenia solium DNA was investigated by using primers (TSF 5'CAGGGTGTGACGTCATGG-3' and TSR 5'-GCTAGGCAACTGGCCTCCT-3') directed against pTsol9, a highly repetitive element of the parasite genome available in GenBank (Accession code: U45987). Sensitivity of $T$. solium DNA detection was evaluated with serial DNA dilutions, showing a lower limit detection of $10 \mathrm{fg}$. Specificity of DNA amplification was demonstrated by the absence of DNA amplification of related parasite species (Taenia saginata, Taenia crassiceps and Schistosoma mansoni), evaluated in silver-stained polyacrylamide gels.

Analyses in clinical samples were conducted in material derived from 30 consecutive patients with NC, all fulfilling Del Brutto's criteria for NC diagnosis (Del Brutto et al., 2001) and 10 non-NC controls (meningeal carcinomatosis, intramedular tumour, exogenous intoxication, tensional headache). Epilepsy was present in 29 patients; intracranial hypertension in one. In 26 patients vesicles were lodged in encephalic parenchyma; cisternal forms were found in two, ventricular form in one and mixed form in another one. Informed consent was obtained from all subjects, after the approval of the study by local ethics committees. PCR was performed in CSF collected after lumbar puncture prescribed for clinical investigations in all subjects. When higher volumes of CSF are used for PCR, enzyme inhibitors may preclude DNA-amplification that can also fail when DNA is not present in sufficient amounts. To circumvent problems related 
to enzyme inhibitors or small amounts of DNA in CSF, we have purified the CSF samples, concentrating the DNA extracted from $100 \mu \mathrm{l}$ of CSF in $25 \mu \mathrm{l}$ of water. All PCR amplifications were tested in triplicates for pure and extracted samples (using $1 \mu \mathrm{l}, 3 \mu \mathrm{l}$ and $5 \mu \mathrm{l})$, resulting in 18 reactions/patient.

Amplifications of $T$. solium DNA from CSF were accomplished for the majority of infected patients $(20 / 30-67 \%)$ by simply using neat CSF (varying from 1 to $5 \mu \mathrm{l}$ ) as template. When purified/concentrated samples, derived from $100 \mu \mathrm{l}$ of CSF were used (1 to $5 \mu \mathrm{l} /$ reaction) we observed that of the 30 tested samples, only one did not evidenced the presence of $T$. solium DNA, resulting in a detection rate of $96.7 \%$. No noticeable reduction in the specificity was seen and NC negative controls remained negative for all replicates in all template dilutions confirming the high specificity of this test. To our knowledge, this is the first demonstration of $T$. solium DNA in the clinical samples of NC patients.

Clinical manifestations of NC are variable and unspecific, depending on the number, localization, morphological type and developmental stage of the cysticerci and the immune response of the host (Garcia et al., 2003). The variety of symptoms (that may include headache, convulsions and cerebral sequels of long term inflammation, which can lead to hydrocephalus, dementia, epilepsy and death) contributes to the complexity of the clinical diagnosis reinforcing the need of developing alternative diagnosis supporting tools.

Absolute diagnostic criteria include the identification of cysticerci, with scolex, in the brain by MRI imaging. In view of its high positive predictive value, MRI is considered as the best method for diagnosis. However, MRI may fail to find image of cysticercus in degeneration, by at least 14 months (6). This results in a surprising low negative predictive value. Immunologic tests for antibodies detection in NC diagnosis are clearly not sufficient to confirm or to discard the infection: (a) Immunoblot (EITB) in the serum has a sensitivity ranging from $14 \%$ in cases with one single active lesion to more than $90 \%$ in cases of more than one active cyst (Sanchez et al., 1999); (b) ELISA in CSF may present high sensitivity and specificity, however specific immunocomplexes may lead to false-negative results in cases with high antigen concentration and cross-reaction may occur with antibodies against other parasites. 
It is important to stand out that not always the patient who presents greater number of cysts will have a standard of stronger amplification: a single active cyst may yield strong amplifications, detected with $1 \mu$ of neat CSF, while patients presenting more active cysts can present less intense amplification profiles. Moreover, PCR was positive in the two NC cases, that were consistently negative for both antigen and antibodies detection, suggesting a better sensitivity of PCR in some cases. Further samples should be assayed to have a better picture of its performance. The reason of PCR failure in detecting one NC case, previously diagnosed by MRI and CSF antibodies, is not clear. It should be noted that this patient was the single case presenting C. racemosus in CSF space, an intense meningeal reaction, and multiple parenchymal calcified cists.

The PCR test described here has very high sensibility (96.7\%) and specificity (100\%). This is a quick and easy test to perform and has a cost that enables its use in the routine, even in the routine available in endemic areas (the total costs per reaction are of about US\$0.50). The demonstration that parasiteDNA is present in CSF of NC patients may have an important impact over the diagnosis of the disease. The high detection rate, absence of unspecific amplifications, simplicity and the low cost of the amplification reaction may encourage the adoption of PCR as an additional diagnostic support for this disease.

Acknowledgments: This work was supported by Associação Beneficente Alzira Denise Hertzog Silva (ABADHS) and Conselho Nacional de Pesquisas do Ministério de Ciência e Tecnologia (CNPq/MCT). AJV was supported by Fundação de Amparo à Pesquisa do Estado de São Paulo (FAPESP) from Brazil. The financing agencies acknowledged here had neither specific interests nor specific roles in the development of this study. 


\section{REFERENCES}

CDC, Centers for Disease Control and Prevention. 1993. Recommendations of the International Task Force for Disease Eradication. MMWR 42:1-25.

Del Brutto, O. H., V. Rajshekhar, A. C. White Jr, V. C. Tsang, T.E. Nash, O.M. Takayanagui, P. M. Schantz, C. A. Evans, A. Flisser, D. Correa, D. Botero, J. C. Allan, E. Sarti, A. E. Gonzalez, R. H. Gilman, H. H. Garcia. 2001. Proposed diagnostic criteria for neurocysticercosis. Neurology 57:177-183.

Earnest, M.P., L. B. Reller, C. M. Filley, A. J. Grek. 1987. Neurocysticercosis in the United States: 35 cases and a review. Rev. Infect. Dis. 9:961-979.

García, H. H., E. Gonzalez, C. A. W. Evans, R. H. Gilman. 2003. Taenia solium cysticercosis. The Lancet 361:547-556.

Ito, A. \& Craig, P. S. 2003. Immunodiagnostic and molecular approaches for the detection of taeniid cestode infections. Trends Parasitol 19:377-381.

Sanchez, A. L., I. Ljungström, M. T. Medina. 1999. Diagnosis of human neurocysticercosis in endemic countries: a clinical study in Honduras. Parasitology International 48:81-89.

Wallin, M. T. \& Kurtzke J. F. 2004. Neurocysticercosis in the United States: review of an important emerging infection. Neurology 63:1559-1564. 
Figure - Evaluation of Taenia solium DNA in LCR of two infected patients. Amplification was conducted for LCR samples of two patients (named Patient 1 and Patient 2) using 1,3 or $5 \mu \mathrm{l}$ of LCR directly as a template for PCR amplification (showed in A) or using 1,3 or $5 \mu$ of DNA extracted from LCR (showed in B). The products were evaluated in $6 \%$ silver-stained polyacrylamide gels.

A

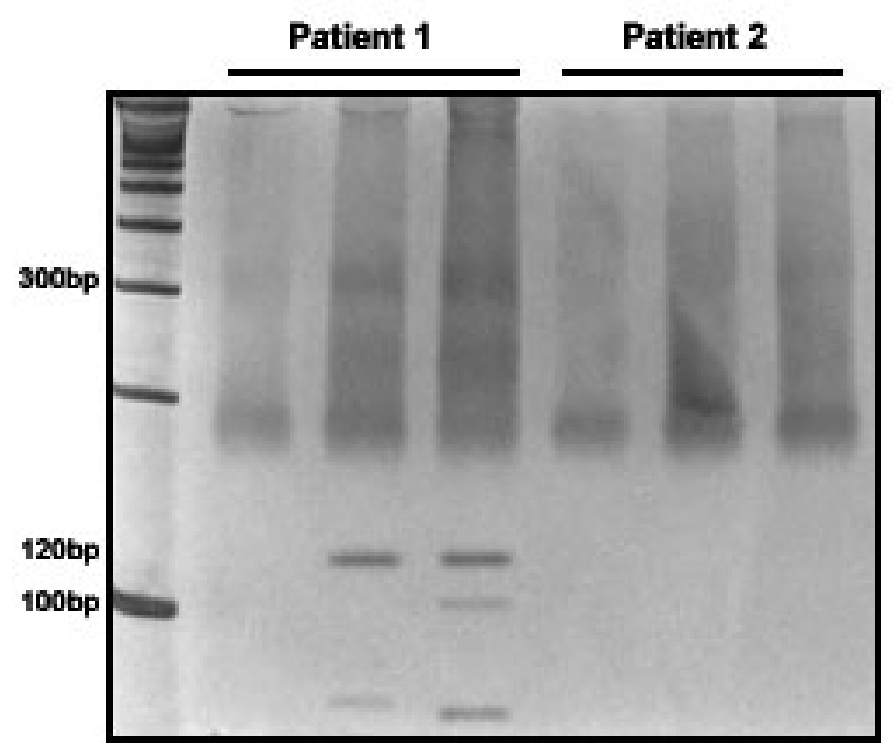

$\begin{array}{lllllll}\operatorname{LCR}(\mu \mathrm{L}) & 1 & 3 & 5 & 1 & 3 & 5\end{array}$
B

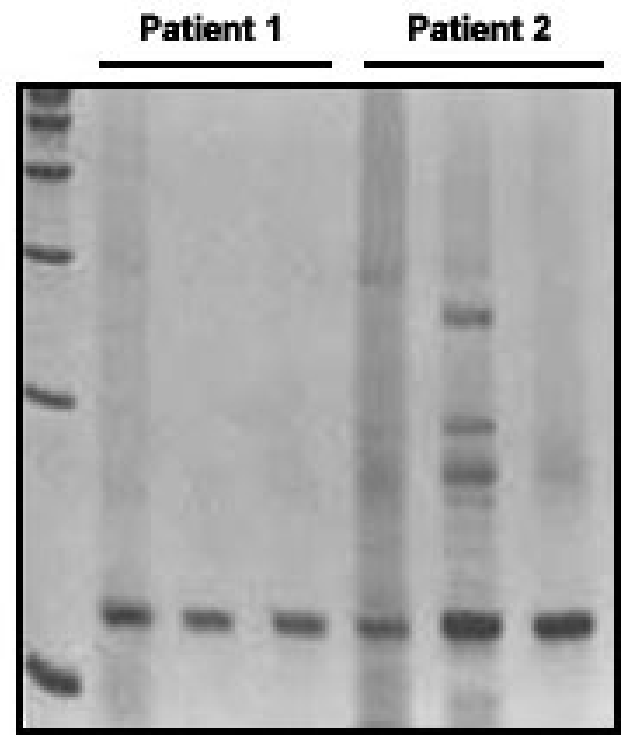

$\begin{array}{llllll}1 & 3 & 5 & 1 & 3 & 5\end{array}$ 